INSTITUTO DE PESQUISAS ENERGÉTICAS E NUCLEARES

Autarquia Associada à Universidade de São Paulo

Síntese de nanopartículas de Pt e PtRh com orientação preferencial (100) suportadas em carbono para a oxidação eletroquímica do etanol e glicerol em meio ácido

NIVALDO GOMES PEREIRA FILHO

Dissertação apresentada como parte dos requisitos para obtenção do Grau de Mestre em Ciências na Área de Tecnologia Nuclear - Materiais.

Orientador:

Prof. Dr. Estevam Vitorio Spinacé

Coorientador:

Prof. Dr. Almir Oliveira Neto 
INSTITUTO DE PESQUISAS ENERGÉTICAS E NUCLEARES

Autarquia Associada à Universidade de São Paulo

Síntese de nanopartículas de Pt e PtRh com orientação preferencial (100) suportadas em carbono para a oxidação eletroquímica do etanol e glicerol em meio ácido

Versão Corrigida

Versão Original disponível no IPEN

NIVALDO GOMES PEREIRA FILHO

Dissertação apresentada como parte dos requisitos para obtenção do Grau de Mestre em Ciências na Área de Tecnologia Nuclear - Materiais.

Orientador:

Prof. Dr. Estevam Vitorio Spinacé

Coorientador:

Prof. Dr. Almir Oliveira Neto 
Fonte de Financiamento: CNPq

Autorizo a reprodução e divulgação total ou parcial deste trabalho, para fins de estudo e pesquisa, desde que citada a fonte.

Como citar:

PEREIRA FILHO, N. G. Síntese de Nanopartículas de Pt e PtRh com Orientação Preferencial (100) Suportadas em Carbono para a Oxidação Eletroquímica do Etanol e Glicerol em Meio Ácido. 2021. 77 f. Dissertação (Mestrado em Tecnologia Nuclear), Instituto de Pesquisas Energéticas e Nucleares, IPEN-CNEN, São Paulo. Disponível em: 〈http://repositorio.ipen.br/〉 (data de consulta no formato: $\mathrm{dd} / \mathrm{mm} /$ aaaa)

Ficha catalográfica elaborada pelo Sistema de geração automática da Biblioteca IPEN, com os dados fornecidos pelo(a) autor(a).

Pereira Filho, Nivaldo Gomes

Síntese de Nanopartículas de Pt e PtRh com Orientação Preferencial (100) Suportadas em Carbono para a Oxidação Eletroquímica do Etanol e Glicerol em Meio Ácido / Nivaldo Gomes Pereira Filho; orientador Estevam Vitorio Spinacé; co-orientador Almir Oliveira Neto. -- São Paulo, 2021.

$77 \mathrm{f}$.

Dissertação (Mestrado) - Programa de Pós-Graduação em Tecnologia Nuclear (Materiais) -- Instituto de Pesquisas Energéticas e Nucleares, São Paulo, 2021.

1. Orientação preferencial. 2. Eletro-oxidação. 3. Etanol. 4. Glicerol. 5. Eletrocatalisadores de Pt e PtRh. I. Spinacé, Estevam Vitorio, orient. II. Oliveira Neto, Almir, co-orient. III. Título. 


\section{AGRADECIMENTOS}

Agradeço a Deus pela vida, saúde e por me abençoar durante todo o caminho que percorri até aqui, tornando possível a conclusão de mais esta etapa.

Aos meus pais e meu irmão, que sempre me apoiam, me ajudam e são uma família maravilhosa.

A minha companheira Flávia Kobata por estar sempre confiante no meu trabalho, fazendo esta caminhada um momento mais calmo e a todos de sua família que torcem para eu conseguir realizar meus objetivos.

Ao meu orientador Dr. Estevam Vitorio Spinacé pelos conhecimentos e conselhos ensinados, me auxiliando e indicando o melhor caminho a seguir.

Ao Dr. Almir Oliveira Neto por sempre me ajudar e aconselhar.

Ao Dr. Rodrigo Fernando Brambilla de Souza e a Dra Andrezza da Silva Ramos pela ajuda na realização dos experimentos e interpretação dos dados de DMS e ATR - FTIR.

Ao Dr. Mauro André Dresch por ser muito mais que um ex orientador, me apresentando essa linha de pesquisa, mas também auxiliou e ajudou na conclusão deste trabalho.

A todos os colegas do Centro de Células a Combustível e Hidrogênio pela ajuda e por tornarem o dia a dia de trabalho mais tranquilo e amigável. Em especial, Eric H. Fontes, Júlio Nandenha, Carlos Eduardo, Luís Marcelo, Conrado, Araceli e Camila.

Ao IPEN pela infraestrutura e ao CNPq pelo auxílio financeiro. 
"Quando a educação não é libertadora, o sonho do oprimido é ser o opressor." Paulo Freire 


\title{
Síntese de nanopartículas de Pt e PtRh com orientação preferencial (100) suportadas em carbono para a oxidação eletroquímica do etanol e glicerol em meio ácido
}

\author{
Nivaldo Gomes Pereira Filho
}

\begin{abstract}
RESUMO
A síntese dos eletrocatalisadores Pt/C e PtRh/C (20\% em massa de metais) foi realizada pelo método da redução por álcool desenvolvido no IPEN-CNEN/SP. A caracterização por EDX apontou que as composições atômicas dos eletrocatalisadores ficaram bem próximas às nominais. O DRX permitiu observar uma possível formação de liga para os materiais binários e também estimar 0 tamanho médio de cristalito para os catalisadores sem direcionamento, o qual foi de aproximadamente $3 \mathrm{~nm}$. Realizou-se ainda uma observação sobre os domínios de superfície dos eletrocatalisadores, mostrando que os materiais com orientação preferencial apresentaram domínios de superfície $\mathrm{Pt}(100)$ mais intensos que os demais. Imagens de MET mostraram que a maioria das nanopartículas de Pt e PtRh sintetizadas com crescimento preferencial na direção (100) possuem morfologia cúbica com tamanhos médios entre 8 e $9 \mathrm{~nm}$. Pelo stripping de CO notou-se que a eletro-oxidação de uma monocamada de CO ocorre em menores potenciais para os catalisadores com orientação preferencial. Experimentos em célula unitária mostraram que os eletrocatalisadores bimetálicos $\mathrm{PtRh} / \mathrm{C}$ (com ou sem orientação) apresentaram melhor desempenho para as reações propostas (EOR e GOR) e ainda que os materiais com orientação preferencial na direção (100) são bem mais ativos quando consideramos sua área eletroquimicamente ativa. Experimentos de DMS e medições de ATR - FTIR revelaram, para EOR, que os eletrocatalisadores com orientação preferencial na direção (100) levam à formação de produtos mais oxidados. Para GOR os resultados de DMS e ATR - FTIR mostraram que, assim como os eletrocatalisadores binários PtRh, os eletrocatalisadores com orientação preferencial não produziram todos os compostos investigados.
\end{abstract}

Palavras-chave: Orientação preferencial, Eletro-oxidação, Etanol, Glicerol, Eletrocatalisadores de Pt e PtRh. 


\title{
Synthesis of carbon-supported Pt AND PtRh nanoparticles with (100) preferential orientation for the electrochemicaloxidation of ethanol and glycerol in acid medium
}

\section{Nivaldo Gomes Pereira Filho}

\begin{abstract}
The synthesis of $\mathrm{Pt} / \mathrm{C}$ and $\mathrm{PtRh} / \mathrm{C}$ electrocatalysts (20\% in mass of metals) was performed by the alcohol reduction method developed at IPEN-CNEN/SP. The characterization by EDX indicated that the atomic compositions of the electrocatalysts were very close to the nominal ones. The XRD allowed us to observe a possible alloy formation for the binary materials and also to estimate the average crystallite size for the undirected catalysts, which was approximately $3 \mathrm{~nm}$. An observation on the surface domains of the electrocatalysts was also performed, showing that the materials with preferential orientation presented more intense $\mathrm{Pt}(100)$ surface domains than the others. MET images showed that most of the Pt and PtRh nanoparticles synthesized with preferential growth in the (100) direction have cubic morphology with average sizes between 8 and $9 \mathrm{~nm}$. By CO stripping it was noted that electro-oxidation of a $\mathrm{CO}$ monolayer occurs at lower potentials for the catalysts with preferential orientation. Unit cell experiments showed that the $\mathrm{PtRh} / \mathrm{C}$ bimetallic electrocatalysts (with or without orientation) showed better performance for the proposed reactions (EOR and GOR) and also that the materials with preferential orientation in the (100) direction are much more active when considering their electrochemically active area. DMS experiments and ATR - FTIR measurements revealed, for EOR, that electrocatalysts with preferential orientation in the (100) direction lead to the formation of more oxidized products. For GOR the, DMS and ATR - FTIR results, as well as for the binary electrocatalysts PtRh, showed that the electrocatalysts with preferential orientation did not produce all the investigated compounds.
\end{abstract}

Keywords: Preferential orientation, Electro-oxidation, Ethanol, Glycerol, Pt and PtRh electrocatalysts. 


\section{LISTA DE TABELAS}

Página

Tabela 1 - Composição química dos eletrocatalisadoes obtida pela técnica EDX (20\% em massa de metais e razão atômica Pt:Rh de 95:5). 34

Tabela 2 - Tamanho médio de cristalito ( $\mathrm{Pt} / \mathrm{C}$ e $\mathrm{PtRh} / \mathrm{C})$, tamanho médio de nanopartícula (Pt/C (100) e PtRh/C (100)) e intensidade relativa dos picos $\mathrm{Pt}(111) / \mathrm{Pt}(200)$ para os eletrocatalisadores estudados. .38

Tabela 3 - Potenciais médios de início da oxidação do etanol e densidade máxima de corrente dos eletrocatalisadores Pt/C, Pt/C Basf, Pt/C (100), PtRh/C e PtRh/C (100).

Tabela 4 - Valores finais de densidade de corrente para os eletrocatalisadores $\mathrm{Pt} / \mathrm{C}, \mathrm{Pt} / \mathrm{C}$ Basf, Pt/C (100), PtRh/C e PtRh/C (100).........................................50 Tabela 5 - Potencial de circuito aberto obtido em uma DEFC para os eletrocatalisadores estudados. .52

Tabela 6 - Densidade máxima de potência obtido em uma DEFC para os eletrocatalisadores estudados. .52

Tabela 7 - Potencial de circuito aberto obtido em uma DEFC para os eletrocatalisadores estudados. 60

Tabela 8 - Densidade máxima de potência obtido em uma DGFC para os eletrocatalisadores estudados. 60

Tabela 9 - Produtos da oxidação parcial do glicerol em meio ácido sob eletrocatalisadores a base de platina, suas massas moleculares e bandas detectáveis no FTIR .62 


\section{LISTA DE FIGURAS}

Página

Figura 1 - Esquema de funcionamento de uma DEFC 19

Figura 2 - Via geral de oxidação do etanol em meio ácido, intermediários e produtos finais gerados. .23

Figura 3 - Esquema das vias de reações propostas para a eletro-oxidação do glicerol utilizando catalisadores a base de platina em meio ácido .25

Figura 4 - Fluxograma das sínteses realizadas no trabalho 29

Figura 5 - a) Micrografia do eletrocatalisador Pt/C (100) e b) histograma com a distribuição do tamanho das nanopartículas. 35

Figura 6 - a) Micrografia do eletrocatalisador PtRh/C (100) e b) histograma com a distribuição do tamanho das nanopartículas. .36

Figura 7 - Difratogramas de raios X para os eletrocatalisadores Pt/C, Pt/C (100), $\mathrm{PtRh} / \mathrm{C}$ e PtRh/C (100) sintetizados pelo método de redução por álcool

Figura 8 - Experimento de stripping de $\mathrm{CO}$ do eletrocatalisador $\mathrm{Pt} / \mathrm{C}$ (Basf) realizado com velocidade de varredura de $50 \mathrm{mV} \mathrm{s}^{-1}$ em solução $0,5 \mathrm{~mol} \mathrm{~L}^{-1}$ de $\mathrm{H}_{2} \mathrm{SO}_{4}$. 39

Figura 9 - Experimento de stripping de $\mathrm{CO}$ do eletrocatalisador $\mathrm{Pt} / \mathrm{C}$ realizado com velocidade de varredura de $50 \mathrm{mV} \mathrm{s}^{-1}$ em solução $0,5 \mathrm{~mol} \mathrm{~L}^{-1}$ de $\mathrm{H}_{2} \mathrm{SO}_{4}$ 39 Figura 10 - Experimento de stripping de CO do eletrocatalisador Pt/C (100), sintetizado com orientação preferencial, realizado com velocidade de varredura de $50 \mathrm{mV} \mathrm{s}^{-1}$ em solução $0,5 \mathrm{~mol} \mathrm{~L}^{-1}$ de $\mathrm{H}_{2} \mathrm{SO}_{4}$

Figura 11 - Experimentos de stripping de $\mathrm{CO}$ dos eletrocatalisadores, $\mathrm{PtRh} / \mathrm{C} \mathrm{em}$ a) e PtRh/C (100) em b), realizados com velocidade de varredura de $50 \mathrm{mV} \mathrm{s}^{-1} \mathrm{em}$ solução $0,5 \mathrm{~mol} \mathrm{~L}^{-1}$ de $\mathrm{H}_{2} \mathrm{SO}_{4}$.

Figura 12 - Voltamograma cíclico do eletrocatalisador Pt/C (Basf) em solução 0,5 $\mathrm{mol} \mathrm{L}^{-1}$ de $\mathrm{H}_{2} \mathrm{SO}_{4}$ com velocidade de varredura de $50 \mathrm{mV} \mathrm{s}^{-1}$ 43

Figura 13 - Voltamograma cíclico do eletrocatalisador $\mathrm{Pt} / \mathrm{C}$ em solução $0,5 \mathrm{~mol} \mathrm{~L}^{-1}$ de $\mathrm{H}_{2} \mathrm{SO}_{4}$ com velocidade de varredura de $50 \mathrm{mV} \mathrm{s}^{-1}$

Figura 14 - Voltamograma cíclico do eletrocatalisador Pt/C (100) em solução $0,5 \mathrm{~mol} \mathrm{~L}^{-1}$ de $\mathrm{H}_{2} \mathrm{SO}_{4}$ com velocidade de varredura de $50 \mathrm{mV} \mathrm{s}^{-1}$ 
Figura 15 - Voltamograma cíclico do eletrocatalisador PtRh/C em solução 0,5

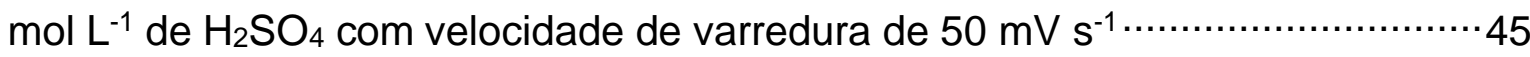
Figura 16 - Voltamograma cíclico do eletrocatalisador PtRh/C (100) em solução $0,5 \mathrm{~mol} \mathrm{~L}^{-1}$ de $\mathrm{H}_{2} \mathrm{SO}_{4}$ com velocidade de varredura de $50 \mathrm{mV} \mathrm{s}^{-1}$

Figura 17 - Voltamograma linear potenciostático dos eletrocatalisadores $\mathrm{Pt} / \mathrm{C}, \mathrm{Pt} / \mathrm{C}$ Basf, Pt/C (100), PtRh/C e PtRh/C (100), em solução $0,5 \mathrm{~mol} \mathrm{~L}^{-1}$ de $\mathrm{H}_{2} \mathrm{SO}_{4}$ e 1,0 $\mathrm{mol} \mathrm{L}^{-1}$ de etanol com velocidade de varredura de $50 \mathrm{mV} \mathrm{s}^{-1}$

Figura 18 - Cronoamperometria dos eletrocatalisadores $\mathrm{Pt} / \mathrm{C}, \mathrm{Pt} / \mathrm{C}$ Basf, $\mathrm{Pt} / \mathrm{C}$ (100), PtRh/C e PtRh/C (100) obtidas com potencial fixo de $0,5 \mathrm{~V}$ em solução $0,5 \mathrm{~mol} \mathrm{~L}^{-1}$ de $\mathrm{H}_{2} \mathrm{SO}_{4}$ e $1,0 \mathrm{~mol} \mathrm{~L}^{-1}$ de etanol.

Figura 19 - Curvas de polarização e densidade de potência para os eletrocatalisadores estudados. a) curva de polarização; b) curva de densidade de potência, ambos normalizados por área geométrica do eletrodo. c) curva de polarização; d) curva de densidade de potência, ambos normalizados por área eletroquimicamente ativa

Figura 20 - Resultados dos espectrômetros de massas eletroquímica diferencial para os eletrocatalisadores estudados, analisados pelo efluente de uma DEFC. 54 Figura 21 - Resultados dos experimentos de espectroscopia na região do infravermelho com transformada de Fourier e refletância total atenuada, analisados pelo efluente de uma DEFC, para os eletrocatalisadroes Pt/C Basf, em a) e Pt/C em b) 55

Figura 22 - Resultados dos experimentos de espectroscopia na região do infravermelho com transformada de Fourier e refletância total atenuada, analisados pelo efluente de uma DEFC, para os eletrocatalisadroes Pt/C (100), em a) e PtRh/C em b). .56

Figura 23 - Resultado do experimento de espectroscopia na região do infravermelho com transformada de Fourier e refletância total atenuada, analisados pelo efluente de uma DEFC, para o eletrocatalisador PtRh/C (100).

Figura 24 - Curvas de polarização e densidade de potência para os eletrocatalisadores estudados. a) curva de polarização; b) curva de densidade de potência, ambos normalizados por área geométrica do eletrodo. c) curva de polarização; d) curva de densidade de potência, ambos normalizados por área eletroquimicamente ativa 
Figura 25 - Resultados dos espectrômetros de massas eletroquímica diferencial para os eletrocatalisadores estudados, relacionado aos produtos com $\mathrm{m} / \mathrm{z}$ de 44 a 90 , analisados pelo efluente de uma DGFC

Figura 26 - Resultados dos espectrômetros de massas eletroquímica diferencial para os eletrocatalisadores estudados, relacionado aos produtos com m/z de 104 a 120, analisados pelo efluente de uma DGFC. 64

Figura 27 - Resultados dos experimentos de espectroscopia na região do infravermelho com transformada de Fourier e refletância total atenuada, analisados pelo efluente de uma DGFC, para os eletrocatalisadroes Pt/C Basf, em a) e Pt/C em b). .65

Figura 28 - Resultados dos experimentos de espectroscopia na região do infravermelho com transformada de Fourier e refletância total atenuada, analisados pelo efluente de uma DGFC, para os eletrocatalisadroes Pt/C (100), em a) e PtRh/C em b). .67

Figura 29 - Resultados dos experimentos de espectroscopia na região do infravermelho com transformada de Fourier e refletância total atenuada, analisados pelo efluente de uma DGFC, para o eletrocatalisador PtRh/C (100). .69 


\section{LISTA DE ABREVIAÇÕES}

ATR - FTIR - Espectroscopia na região do infravermelho com Transformada de Fourier e Refletância Total Atenuada.

ATR - SEIRAS - Espectroscopia de Absorção na região do infravermelho, aprimorada na superfície acoplada com Refletância Total Atenuada.

DAFC - Célula a combustível alimentada diretamente com álcool.

DEFC - Célula a combustível alimentada diretamente com etanol.

DGFC - Célula a combustível alimentada diretamente com glicerol.

DMS - Espectrometria de massas diferencial.

DRX - Difração de raios $X$.

EDX - Espectroscopia de energia dispersiva de raios $\mathrm{X}$.

EOR - Reação de oxidação do etanol.

GOR - Reação de oxidação do glicerol.

IRAS - Espectroscopia de Absorção na região do infravermelho.

MET - Microscopia eletrônica de transmissão.

VC - Voltametria cíclica. 


\section{SUMÁRIO}

1 INTRODUÇÃO

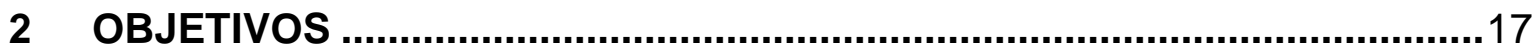

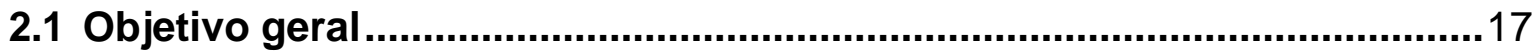

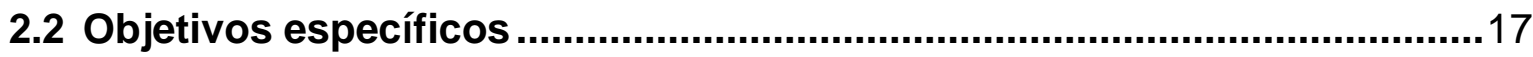

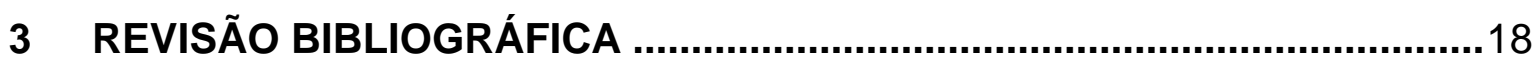

3.1 Células a combustível de etanol direto (DEFC) .........................................18

3.1.1 Catalisadores para a oxidação eletroquímica do etanol ....................20

3.2 Células a combustível de glicerol direto (DGFC) .......................................24

3.2.1 Catalisadores para a oxidação eletroquímica do glicerol...................26

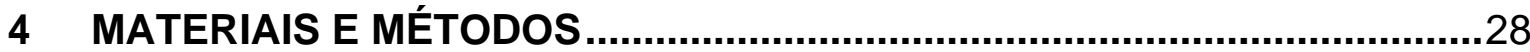

4.1 Síntese das nanopartículas de Pt e PtRh com orientação preferencial na direção (100) suportadas em carbono (eletrocatalisadores $\mathrm{Pt} / \mathrm{C}$ e PtRh/C) ...28

4.2 Caracterização físico-química dos eletrocatalisadores..............................29

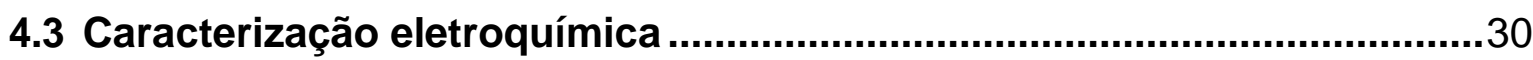

4.4 Ensaios em célula a combustível do tipo DEFC e DGFC ……....................31

4.4.1 Preparação do conjunto eletrodo-membrana-eletrodo (MEA) ............31

4.5 Análise de espectrometria de massas diferencial (DMS) ..........................32

4.6 Espectroscopia na região do infravermelho com Transformada de Fourier e Refletância Total Atenuada (ATR-FTIR) .............................................32

5 RESULTADOS E DISCUSSÃO

5.1 Composição atômica nominal e experimental (EDX)..................................34

5.2 Microscopia eletrônica de transmissão (MET) .............................................35

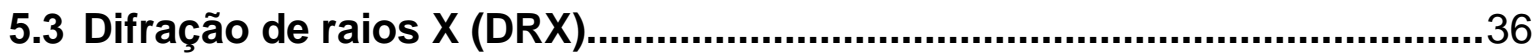

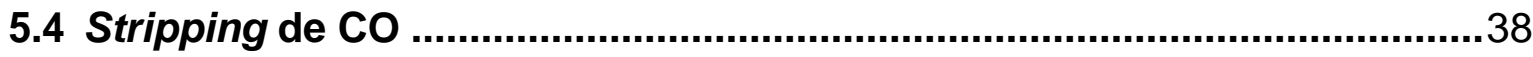

5.5 Voltametria cíclica em meio ácido..........................................................

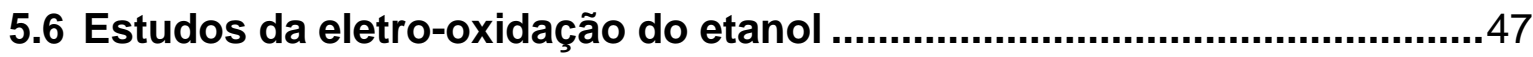

5.6.1 Voltametria cíclica e Cronoamperometria ........................................4

5.6.2 Experimentos em célula a combustível de etanol direto ....................51

5.6.3 Estudos on-line da eletro-oxidação do etanol por espectrometria de massas diferencial (DMS) e análise dos efluentes da DEFC por ATR-FTIR.53

5.7 Estudos da eletro-oxidação do glicerol .....................................................59

5.7.1 Experimentos em célula a combustível de glicerol direto .................59

5.7.2 Estudos on-line da eletro-oxidação do glicerol por espectrometria de massas diferencial (DMS) e análise dos efluentes da DGFC por ATR-FTIR.61 


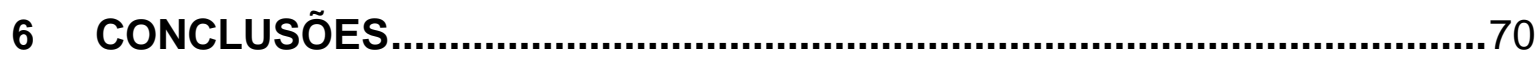

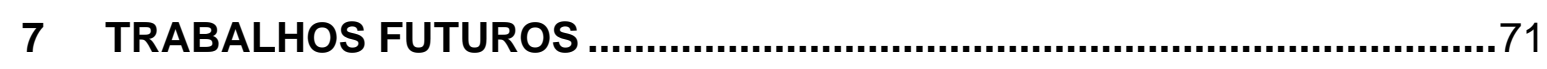

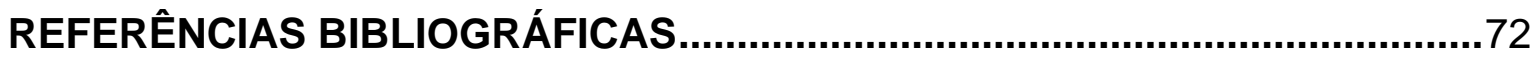




\section{INTRODUÇÃO}

O consumo de energia pelo ser humano é fundamental para a realização de diversas atividades, tanto sociais quanto econômicas, sendo as fontes energéticas classificadas como não renováveis e renováveis. As fontes não renováveis são representadas pelo petróleo, gás natural e carvão mineral. Por outro lado, as fontes renováveis são comumente definidas como energia gerada a partir de energia solar, eólica, geotérmica, maré/onda, madeira, resíduos e biomassa. Ou seja, a energia renovável é limpa, segura e inesgotável (APERGIS E DANULETIU, 2014).

Com o crescimento contínuo do consumo energético a nível mundial e consequentemente a degradação e poluição do meio ambiente, gerados para a produção dessa energia pelos métodos tradicionais (fontes não renováveis), observa-se o crescimento do número de pesquisas sobre a busca por fontes energéticas alternativas, que possam suprir nossas necessidades sem causar tantos danos ao meio ambiente (MARCZYNSKI, 2013; SPINACÉ, 2016).

Assim, visando reverter esse quadro e reduzir a dependência da utilização das fontes não renováveis, várias tecnologias de baixo impacto ambiental vêm sendo desenvolvidas. Entre as principais tecnologias estão as pesquisas sobre desenvolvimento de células a combustível (LINARDI et al., 2012; MARCZYNSKI, 2013). Esses dispositivos convertem energia química de um combustível diretamente em energia elétrica com baixa emissão de poluentes LINARDI et al. (2012), além de apresentarem elevada densidade de potência e uma alta eficiência energética, quando comparadas às máquinas térmicas, podendo ser empregadas como fontes estacionárias, móveis (veiculares) e portáteis (DRESCH, 2014).

Células a combustível são comumente classificadas segundo o eletrólito utilizado e temperatura de operação. As células de baixa temperatura de operação (temperatura de operação entre a temperatura ambiente até $200^{\circ} \mathrm{C}$ ) que incluem: células alcalinas (AFC), célula a ácido fosfórico (PAFC) e a célula a membrana polimérica trocadora de prótons (PEMFC). Já as células de alta temperatura de operação (temperatura de operação na faixa 600-1000 ํㅡ) são as células a carbonato fundido (MCFC) e as células cerâmicas (SOFC) (FUEL CELL HANDBOOK, 2000; BRANDALISE, 2010; ANTONIASSI, 2013). 
Dentre essas, as que se destacam com maior número de pesquisas são as células do tipo PEMFC (Proton Exchange Membrane Fuel Cell) que tem como característica fundamental a utilização de polímeros como eletrólito. As PEMFC's se sobressaem entre as demais por apresentarem elevada densidade de potência e facilidade de operação, tendo como principal constituinte o conjunto eletrodomembrana-eletrodo MEA (Membrane Electrodes Assembly), onde o eletrodo negativo (ânodo) é responsável pela oxidação do combustível a prótons $\left(\mathrm{H}^{+}\right)$e elétrons $\left(\mathrm{e}^{-}\right)$. Os prótons são transportados até o eletrodo positivo (cátodo) através da membrana trocadora de prótons (eletrólito), enquanto que os elétrons são direcionados externamente (do ânodo para o cátodo) originando uma corrente elétrica. No cátodo ocorrem as reações de redução de oxigênio que, juntamente com os prótons e elétrons gerados no compartimento anódico, produz água e calor (LINARDI et al., 2012).

O principal combustível utilizado em células PEMFC é o Hidrogênio $\left(\mathrm{H}_{2}\right)$, que pode ser proveniente tanto de fontes fósseis, desde que previamente purificado, quanto da eletrólise da água. O hidrogênio quando utilizado como combustível nas células a combustível, apresenta alto desempenho energético (alta densidade de energia) se comparado aos combustíveis primários, como metanol e etanol. Entretanto, este combustível apresenta certas desvantagens, tais como, dificuldade para ser inserido no mercado, devido ao elevado custo de produção e também problemas relacionados ao armazenamento e distribuição (LINARDI, 2010). Contudo, as células PEMFC's apresentam versatilidade quanto aos possíveis combustíveis a serem utilizados, podendo utilizar álcoois de forma direta e denominadas de maneira geral como DAFC (Direct Alcohol Fuel Cell) (LINARDI, 2010; MARCZYNSKI, 2013).

Dentre as células DAFC, destacam-se as alimentadas por etanol de maneira direta que são denominadas DEFC (Direct Ethanol Fuel Cell) (FUEL CELL HANDBOOK, 2000; MARCZYNSKI, 2013). O etanol apresenta certas vantagens em sua utilização, pois já existe uma infraestrutura bem estabelecida para sua produção e distribuição no Brasil, além disso é um combustível liquido renovável onde o ciclo do carbono é considerado neutro. Assim, as células a combustível do tipo DEFC tem se mostrado amplamente promissoras, tanto para operação em meio ácido (PEMFC) quanto em meio alcalino (AFC) (CHEN et al., 2018; YANG et al., 2019; XIE et al., 2019). No entanto, o grande desafio nestas células que operam 
a baixas temperaturas está na quebra das ligações do tipo carbono-carbono presentes na molécula do etanol (KAMARUDIN e AKHAIRI, 2016; XIE et al., 2019). Assim, devido a incompleta reação de oxidação do etanol nas atuais células DEFCs, os principais produtos formados são o ácido acético e o acetaldeído nas células operantes em meio ácido, e o acetato nas células operantes em meio alcalino (KAMARUDIN e AKHAIRI, 2016; XIE et al., 2019). Dessa forma, a busca por catalisadores que efetivamente promovam a eletro-oxidação completa doetanol a $\mathrm{CO}_{2}$ em baixas temperaturas é um desafio nesta área.

Além das células DEFC, as células DGFC - células a combustível de glicerol direto (Direct Glycerol Fuel Cell) também vêm ganhando destaque em estudos recentes para a conversão do glicerol em produtos químicos de maior valor e na geração de energia elétrica (RAHIM et al., 2020).

O glicerol bruto é o principal subproduto gerado durante a fabricação do biodiesel (aproximadamente 10\% peso/peso) e do bioetanol (aproximadamente 7\% peso/peso). Consequentemente, com o aumento da produção de biodiesel e bioetanol nos últimos anos, esses combustíveis de fontes renováveis são fortes candidatos para substituir os combustíveis fósseis. $\mathrm{O}$ glicerol tem sido produzido em excesso e passou a ser considerado uma séria ameaça à indústria de biocombustíveis, devido ao custo de descarte e de purificação serem relativamente altos (MOTA et al., 2009; RAHIM et al., 2020). Assim a conversão do glicerol em produtos químicos de alto valor agregado é descrita como a melhor maneira de substituir os custos de descartes e purificação do glicerol bruto (COUTANCEAU et al., 2019; RAHIM et al., 2020).

Estudos tem mostrado que catalisadores a base de platina suportados em carbono $(\mathrm{Pt} / \mathrm{C})$ e platina ródio suportados em carbono $(\mathrm{PtRh} / \mathrm{C})$ com diferentes morfologias, estruturas (por ex., tipo core-shell) e com orientação preferencial em diferentes direções podem levar a materiais mais ativos e eficientes na eletrooxidação do etanol (ANTONIASSI, 2017; HUANG et al., 2019; SALAZAR-BANDA et al., 2019). Gomes et al. (2012) estudaram a oxidação do glicerol em meio ácido usando cristais de Pt com baixos índices (100), (110) e (111) por voltametria cíclica e FTIR e observou que superfícies de $\mathrm{Pt}(100)$ e $\mathrm{Pt}(110)$ favoreciam a quebra das ligações C-C-C a baixos potenciais formando $\mathrm{CO}$ como intermediário, o qual envenenou estas superfícies até mesmo em altos potenciais, enquanto que $\mathrm{Pt}(111)$ não favoreceu a quebra da ligação C-C-C mesmo em potenciais tão baixos quanto 
$0.05 \mathrm{~V}$. A formação de compostos carbonílicos e de $\mathrm{CO}_{2}$ foi detectada para todas as superfícies de Pt utilizadas. A comparação das intensidades relativas das bandas de $\mathrm{CO}_{2}$ e compostos carbonílicos mostrou que esta razão foi maior para $\mathrm{Pt}(100)$ e $\mathrm{Pt}(110)$ do que para a $\mathrm{Pt}(111)$. 


\section{OBJETIVOS}

\subsection{Objetivo geral}

Sintetizar nanopartículas de Pt e de PtRh com orientação preferencial na direção (100) suportadas em carbono com $20 \%$ em massa de metais e razão atômica entre Pt:Rh de 95:5 para a oxidação eletroquímica do etanol e glicerol em meio ácido.

\subsection{Objetivos específicos}

Caracterizar os eletrocatalisadores $\mathrm{Pt} / \mathrm{C}$ e $\mathrm{PtRh} / \mathrm{C}$ por Difração de raios $X(D R X)$; Espectroscopia de energia dispersiva de raios X (EDX) e Microscopia eletrônica de transmissão (MET).

Avaliar a oxidação eletroquímica do etanol e glicerol em meio ácido utilizando célula a combustível unitária.

Investigar os produtos formados utilizando as técnicas de Espectrometria de massas diferencial (DMS) e Espectroscopia na região do infravermelho com Transformada de Fourier e Refletância Total Atenuada (ATR- FTIR). 


\section{REVISÃo BIBLIOGRÁFICA}

\subsection{Células a combustível de etanol direto (DEFC)}

As primeiras células a combustível que utilizaram álcoois como combustíveis foram as do tipo DMFC (Direct Methanol Fuel Cell) DRESCH (2014), sendo que até hoje tais dispositivos apresentam um estado de desenvolvimento tecnológico mais avançado. Entretanto, problemas relacionados ao uso do metanol, tais como a elevada toxicidade, baixo ponto de ebulição $\left(65^{\circ} \mathrm{C}\right)$, bem como ao fato da produção de metanol ser primordialmente derivada do petróleo fez com que o uso do etanol como combustível se tornasse atrativo (LINARDI, 2010; SALAZARBANDA et al., 2019). O etanol, como combustível em células DEFC tem sido considerado promissor devido a: i) baixa toxicidade; ii) menor permeabilidade através da membrana polimérica; iii) elevada densidade de potência teórica e; iv) ser amigável ao meio-ambiente (DRESCH, 2014; SALAZAR-BANDA et al., 2019). Além disso, sua produção é proveniente de fontes renováveis, como a cana de açúcar, milho, beterraba e biomassa (LINARDI et al., 2000; BRANDALISE, 2010; MARCZYNSKI, 2013).

O funcionamento de uma célula DEFC é basicamente o mesmo de uma PEMFC, onde a diferença primordial é o combustível utilizado. Nestas células, uma solução aquosa de etanol é alimentada diretamente no ânodo, sendo oxidada por um eletrocatalisador produzindo prótons, elétrons e $\mathrm{CO}_{2}$ como observado na Figura 1. 
Figura 1 - Esquema de funcionamento de uma DEFC.

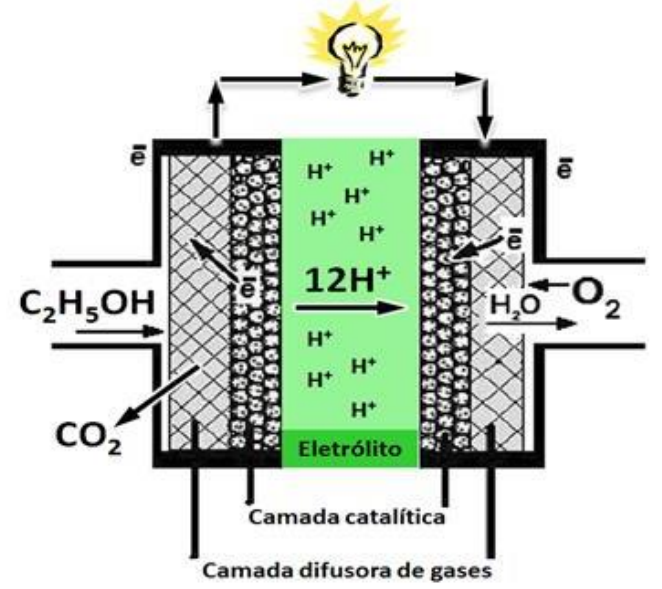

Fonte: Retirado de (LINARDI e BONIFÁCIO, 2011).

Teoricamente, a reação completa em uma DEFC ocorre com a formação de 3 moléculas de água, 2 moléculas de $\mathrm{CO}_{2}$ e fornece ao circuito elétrico 12 elétrons com potencial padrão de 1,145 V (Equações 1-3).

$$
\begin{aligned}
& \text { Ânodo: } \mathrm{CH}_{3} \mathrm{CH}_{2} \mathrm{OH}_{(\mathrm{l})}+3 \mathrm{H}_{2} \mathrm{O}_{(\mathrm{l})} \rightarrow 2 \mathrm{CO}_{2(\mathrm{~g})}+12 \mathrm{H}^{+}(\mathrm{aq})+12 \mathrm{e}^{-} \\
& \text {Cátodo: } 3 \mathrm{O}_{2(\mathrm{~g})}+12 \mathrm{H}^{+}{ }_{(\mathrm{aq})}+12 \mathrm{e}^{-} \rightarrow 6 \mathrm{H}_{2} \mathrm{O}_{(\mathrm{l})}
\end{aligned}
$$

Reação global: $\mathrm{CH}_{3} \mathrm{CH}_{2} \mathrm{OH}_{(\mathrm{l})}+3 \mathrm{O}_{2(\mathrm{~g})} \rightarrow 2 \mathrm{CO}_{2(\mathrm{~g})}+3 \mathrm{H}_{2} \mathrm{O}_{(\mathrm{l})}$

Como visto (Figura 1), os prótons $\left(\mathrm{H}^{+}\right)$são transportados através do eletrólito polimérico e os elétrons fluem pelo circuito externo até o cátodo onde ocorre a redução de oxigênio com consequente formação de água. Todavia, a eletro-oxidação do etanol é mais complexa que a do metanol, devido à dificuldade de rompimento da ligação $\mathrm{C}-\mathrm{C}$, demandando maior energia com formação de intermediários (subprodutos), que envenenam a superfície do eletrocatalisador, diminuindo a eficiência do sistema, fazendo com que a oxidação completa do etanol a $\mathrm{CO}_{2}$ seja pouco favorecida (MARCZYNSKI, 2013). 


\subsubsection{Catalisadores para a oxidação eletroquímica do etanol}

A atividade do eletrocatalisador é de extrema importância numa DEFC, tendo em vista que proporciona a ocorrência das reações em velocidades adequadas e possibilita a aplicação prática das células a combustível (DRESCH, 2009; LINARDI, 2010; LINARDI e BONIFÁCIO, 2011; LINARDI et al., 2012).

No caso das células DEFC, cuja operação acontece em baixas temperaturas, os eletrocatalisadores a base $\mathrm{Pt}$ tem se mostrado os mais ativos DRESCH (2014). No entanto, acetaldeído e ácido acético são os principais produtos formados em meio ácido e acetato em meio básico, sendo somente uma pequena fração do etanol convertida a $\mathrm{CO}_{2}$ (KAMARUDIN e AKHAIRI, 2016; XIE et al., 2019; YANG et al., 2019;). Os eletrocatalisadores utilizados em células DEFC, além de atuarem na quebra das ligações $\mathrm{O}-\mathrm{H}, \mathrm{C}-\mathrm{H}$ e C-C por adsorção química dos respectivos combustíveis, devem ter a capacidade de liberar ou não adsorver intermediários de forma contínua, uma vez que a eletro-oxidação do etanol gera espécies fortemente adsorventes que envenenam e, consequentemente, desativam os sítios de platina (MARCZYNSKI, 2013).

Nesse sentido, pesquisas são direcionadas para o desenvolvimento de eletrocatalisadores mais ativos com a intenção de facilitar a oxidação dos intermediários formados, tais como o monóxido de carbono (CO) e fragmentos do tipo $\mathrm{CHx}$, que bloqueiam os sítios de $\mathrm{Pt}$ diminuindo a atividade catalítica (MARCZYNSKI, 2013). A adição de um segundo ou terceiro metal aos eletrocatalisadores de Pt pode levar a uma melhora da atividade eletrocatalítica, sendo que o co-catalisador atua basicamente por dois mecanismos: i) mecanismo bifuncional, no qual o elemento oxofílico fornece espécies oxigenadas para a oxidação de $\mathrm{CO}$ a $\mathrm{CO}_{2}$ em sobrepotenciais mais negativos que a $\mathrm{Pt}$, ou ii) efeito eletrônico, que devido à forte interação entre os elementos Pt-M, observada em ligas, leva ao enfraquecimento das ligações $\mathrm{Pt}-\mathrm{CO}$, favorecendo assim a dessorção do CO (DRESCH, 2014).

Estudos vem mostrando que a adição de $\mathrm{Rh}$ a eletrocatalisadores de $\mathrm{Pt}$ tem levado a materiais mais seletivos para a formação de $\mathrm{CO}_{2}$ (DIAS, 2009; ARAUJO, 2013). Como catalisador bi-metálico, o efeito sinérgico entre Pt e Rh é verificado, reduzindo o envenenamento da superfície ativa desses metais, o que leva a uma oxidação eletroquímica mais eficiente do etanol (DE SOUZA et al., 2002; 
COLMATI et al., 2008; KOWAL et al., 2009; KAMARUDIN e AKHAIRI, 2016). Vale ressaltar também que o Rh é um metal que possui capacidade de clivagem da ligação C-C, além de formar ligas metálicas com a Pt, de tal maneira a diminuir a energia de ligação entre um adsorbato e o metal (FONTES, 2017). Foi verificado ainda que a morfologia das nanopartículas de platina pode maximizar o rendimento de certas reações ou direcionar a seletividade dos produtos reacionais. $\mathrm{Na}$ oxidação de etanol, superfícies de Pt (100) são mais seletivas para formação de $\mathrm{CO}_{2}$ se comparadas às superfícies (110) e (111) (FELIU et al., 2013; ANTONIASSI, 2017).

Assim, estudos recentes sobre a produção de eletrocatalisadores a base de PtRh com alterações estruturais para a Reação de Oxidação do Etanol (EOR) e outros álcoois vêm sendo pesquisados. HUANG et al. (2019) sintetizaram nanofios de platina-ródio subnanômetro para utilização como eletrocatalisadores na EOR em meio ácido. Por meio de testes eletroquímicos foi obtido um aumento de quase três vezes na atividade catalítica do material preparado, além de uma durabilidade superior em comparação com o Pt/C comercial e o nanofio subnanômetro de Pt/C. Além disso relataram que a estrutura 1D com um diâmetro médio de apenas $1,2 \mathrm{~nm}$ pode efetivamente aumentar a eficiência da utilização do átomo de Pt e acelerara transferência de massa, enquanto que a introdução de Rh não apenas pode fornecer espécies $\mathrm{OH}^{-}$abundantes para aliviar o efeito de envenenamento, mas também pode aumentar a seletividade para formação de $\mathrm{CO}_{2}$ na EOR, melhorando ainda mais o desempenho do eletrocatalisador.

SONG et al. (2019) desenvolveram um método sintético controlado pela adição de precursores para preparar nanocubos de PtRh, com tamanhos ajustáveis usando cloreto de ródio e acetato de ródio. Os nano cubos de PtRh $(5,5 \mathrm{~nm})$ apresentaram considerável atividade eletroquímica e estabilidade muito melhores, com atividade catalítica específica 6 vezes superior aos catalisadores de $\mathrm{Pt} / \mathrm{C}$, quando comparados para a reação de oxidação do etileno glicol (EGOR). Os comportamentos catalíticos aprimorados foram atribuídos à introdução do cocatalisador Rh, eficiente para a promoção do efeito eletrônico e de formação de liga, bem como da estrutura cúbica em nano escala que aumenta a resistência ao envenenamento da superfície catalítica.

YANG et al. (2019) estudaram a adsorção e oxidação de etanol em eletrocatalisadores de Rh em meio alcalino por Espectroscopia de Absorção na 
região do infravermelho, aprimorada na superfície acoplada com Refletância Total Atenuada (ATR-SEIRAS) e Espectroscopia de Absorção na região do infravermelho, aprimorada na superfície (IRAS). Foi verificado que o etanol realiza facilmente a auto dissociação em uma superfície de $R$ h, podendo dividir a ligação C-C de etanol para gerar espécies superficiais de $\mathrm{CO}_{a d}$ e $\mathrm{CHx}$, o que é significativamente importante no aprimoramento da completa EOR. O potencial de oxidação inicial do etanol em $\mathrm{Rh}$ foi diminuído pelo menos $180 \mathrm{mV}$ em relação ao eletrodo de Pd e Pt. Além disso descreveram ainda que o etanol pode ser eletrooxidado completamente a $\mathrm{CO}_{2}$ na superfície $\mathrm{Rh}$ quando o potencial aplicado varia de 0,4 a $0,6 \mathrm{~V}$.

CHEN et al. (2018) projetaram e sintetizaram nanoboxes cúbicos de PtRhCu porosos pela reação galvânica entre $\mathrm{K}_{2} \mathrm{PtCl}_{4}, \mathrm{RhCl}_{3}$ e $\mathrm{Cu}_{2} \mathrm{O}$ e testaram frente à EOR em meio de $\mathrm{KOH}$. Eles observaram que o potencial de início de oxidação foi $260 \mathrm{mV}$ menor para o material preparado e também que a densidade de corrente gerada na EOR foi 2,9 vezes maior comparado a Pt/C policristalina. Verificaram ainda que o potencial de oxidação de CO deslocou negativamente em $30 \mathrm{mV}$ comparado com Pt/C. Testes de cronoamperometria exibiram uma maior atividade e estabilidade para os nanoboxes cúbicos de PtRhCu em comparação a $\mathrm{Pt} / \mathrm{C}$, sendo que a densidade final de corrente foi 6 vezes maior. Eles relatam que a introdução do elemento Rh não é apenas benéfica para a clivagem da ligação CC, mas também benéfica para melhorar a estabilidade do catalisador.

XIE et al. (2019) realizaram a síntese de nanocubos core-shell Rh@Pt ajustáveis a concavidades abaixo de $10 \mathrm{~nm}$ para servir como eletrocatalisadores ativos para o EOR em meios ácidos. Os materiais estudados exibiram catálise EOR bastante aprimorada em comparação com a Pt pura, tendo uma densidade de corrente 6,89 vezes superior aos catalisadores comerciais de $\mathrm{Pt} / \mathrm{C}$. Ensaios de cronoamperometria apresentaram uma densidade de corrente continuamente mais alta por uma duração prolongada para os nanocubos core-shell Rh@Pt, exibindo uma capacidade ante envenenamento aprimorada e dependente da concavidade. Estudos eletroquímicos in situ de Espectroscopia na região do infravermelho com Transformada de Fourier (FTIR) indicaram que a interação interfacial Rh-Pt e as etapas atômicas de superfície superior Pt nos nanocubos côncavos core-shell Rh@Pt podem efetivamente facilitar a clivagem da ligação C-C em direção a uma oxidação completa do etanol em $\mathrm{CO}_{2}$. 
SALAZAR-BANDA et al. (2019) estudaram nanopartículas de $\mathrm{Pt}{ }_{3} \mathrm{Rh} / \mathrm{C}$ altamente ativas para a eletro-oxidação do etanol em meio ácido. O catalisador $\mathrm{Pt}_{3} \mathrm{Rh} / \mathrm{C}$ mostrou a maior atividade em relação à oxidação do etanol, apresentando densidades de corrente em uma condição quase estacionária cerca de 5,2 vezes maior que o $\mathrm{Pt} / \mathrm{C}$ comercial. Dados in situ de FTIR revelaram que o catalisador $\mathrm{Pt} / \mathrm{C}$ favorece à formação de ácido acético, em contrapartida para $\mathrm{Pt}_{3} \mathrm{Rh} / \mathrm{C}$, até $850 \mathrm{mV}$, a quebra de ligação $\mathrm{C}-\mathrm{C}$ e a formação de $\mathrm{CO}_{2}$ como produto é a reação dominante. O desempenho catalítico superior e a maior seletividade para a formação de $\mathrm{CO}_{2}$ com baixos potenciais para o catalisador $\mathrm{Pt}_{3} \mathrm{Rh} / \mathrm{C}$ foi atribuído à sinergia entre os metais e à presença da liga na estrutura do catalisador.

É descrito que a EOR ocorre basicamente por dois caminhos, como apresentado na Figura 2, sendo que o caminho 2 é o principal observado nos trabalhos até agora realizados. Com isso, o desenvolvimento de eletrocatalisadores que maximizem a EOR por meio do caminho 1 é de extrema importância para melhoria do desempenho das DEFC e consequente viabilidade de aplicaçãodessas em nível comercial.

Figura 2 - Via geral de oxidação do etanol em meio ácido, intermediários e produtos finais gerados.

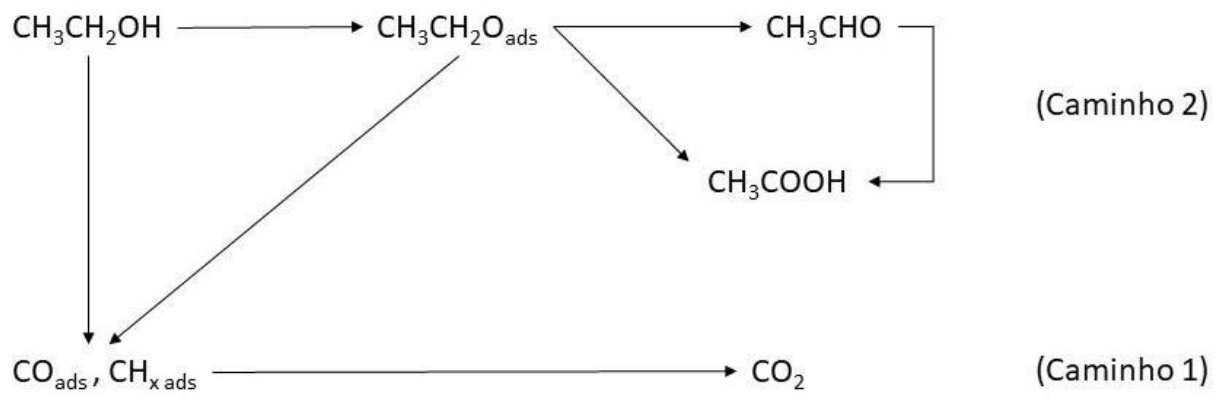

*os termos ads significa que as moléculas estão adsorvidas no sítio ativo da superfície do catalisador. 


\subsection{Células a combustível de glicerol direto (DGFC)}

Durante as duas últimas décadas muitos governos impuseram políticas rígidas para a redução do consumo de combustíveis fósseis, aumentando assim o consumo dos combustíveis "verdes" (derivados de fontes renováveis). Com isso, a produção global de biodiesel aumentou consideravelmente, contribuindo diretamente para um aumento na produção do subproduto glicerol (DIRECT LIQUID FUEL CELLS, 2021; AHMAD et al., 2021). Estequiometricamente, cerca de 10\% em peso de glicerol bruto é gerado a partir da produção total de biodiesel, sendo que este produto tem grande potencial a ser valorizado para obtenção de produtos químicos de valor agregado mais valioso (MOSTAFAZADEH et al., 2021; DIRECT LIQUID FUEL CELLS, 2021).

O glicerol como combustível nas DGFC produz não somente eletricidade, mas também permite a formação de subprodutos valiosos por meio da oxidação incompleta deste álcool. Ou seja, a conversão eletroquímica do glicerol é uma tecnologia nova e simples, constituindo um método promissor para produzir produtos de alto valor agregado além de energia elétrica. Esta técnica tem sido estudada devido à simplicidade de operação, estrutura e a não necessitando de utilização direta de reagentes químicos para processamento do glicerol (MOSTAFAZADEH et al., 2021; DIRECT LIQUID FUEL CELLS, 2021).

Quando utilizado como combustível em uma célula de glicerol direto este álcool pode fornecer 14 elétrons por molécula oxidada (considerando sua conversão total à $\mathrm{CO}_{2}$ ) ZANATA et al. (2016), como mostrado nas reações 4, 5 e 6 .

Ânodo: $\mathrm{C}_{3} \mathrm{H}_{8} \mathrm{O}_{3(l)}+3 \mathrm{H}_{2} \mathrm{O}_{(l)} \rightarrow 3 \mathrm{CO}_{2(\mathrm{~g})}+14 \mathrm{H}^{+}{ }_{(\mathrm{aq})}+14 \mathrm{e}^{-}$

Cátodo: $3,5 \mathrm{O}_{2(\mathrm{~g})}+14 \mathrm{H}^{+}(\mathrm{aq})+14 \mathrm{e}^{-} \rightarrow 7 \mathrm{H}_{2} \mathrm{O}_{(\mathrm{l})}$

Reação global: $\mathrm{C}_{3} \mathrm{H}_{8} \mathrm{O}_{3(l)}+3,5 \mathrm{O}_{2(g)} \rightarrow 3 \mathrm{CO}_{2(g)}+4 \mathrm{H}_{2} \mathrm{O}_{(l)}$

Assim como nas demais células a combustível que utilizam álcoois de maneira direta, observa-se que no ânodo ocorre a reação de oxidação do combustível, produzindo prótons, elétrons e dióxido de carbono. No cátodo há o consumo de oxigênio e produção de água. Para o caso específico do glicerol, sua oxidação total 
gera 3 moléculas de $\mathrm{CO}_{2}$ e 4 moléculas de água. Porém, como já comentado, a eletro-oxidação incompleta do glicerol para a geração de produtos químicos de maior valor agregado tem tido maior atenção do que estudos de sua total oxidação para a geração de energia elétrica (GOMES et al., 2013).

De acordo com COUTANCEAU, BARANTON e KOUAMÉ (2019) os produtos formados por meio da eletro-oxidação do glicerol em meio ácido utilizando catalisadores a base de platina depende de alguns fatores, como a composição do catalisador, o eletrólito suporte utilizado e o potencial aplicado. Resumidamente, os produtos formados a partir da eletro-oxidação do glicerol em meio ácido estão apresentados na Figura 3.

Figura 3 - Esquema das vias de reações propostas para a eletro-oxidação do glicerol utilizando catalisadores a base de platina em meio ácido.

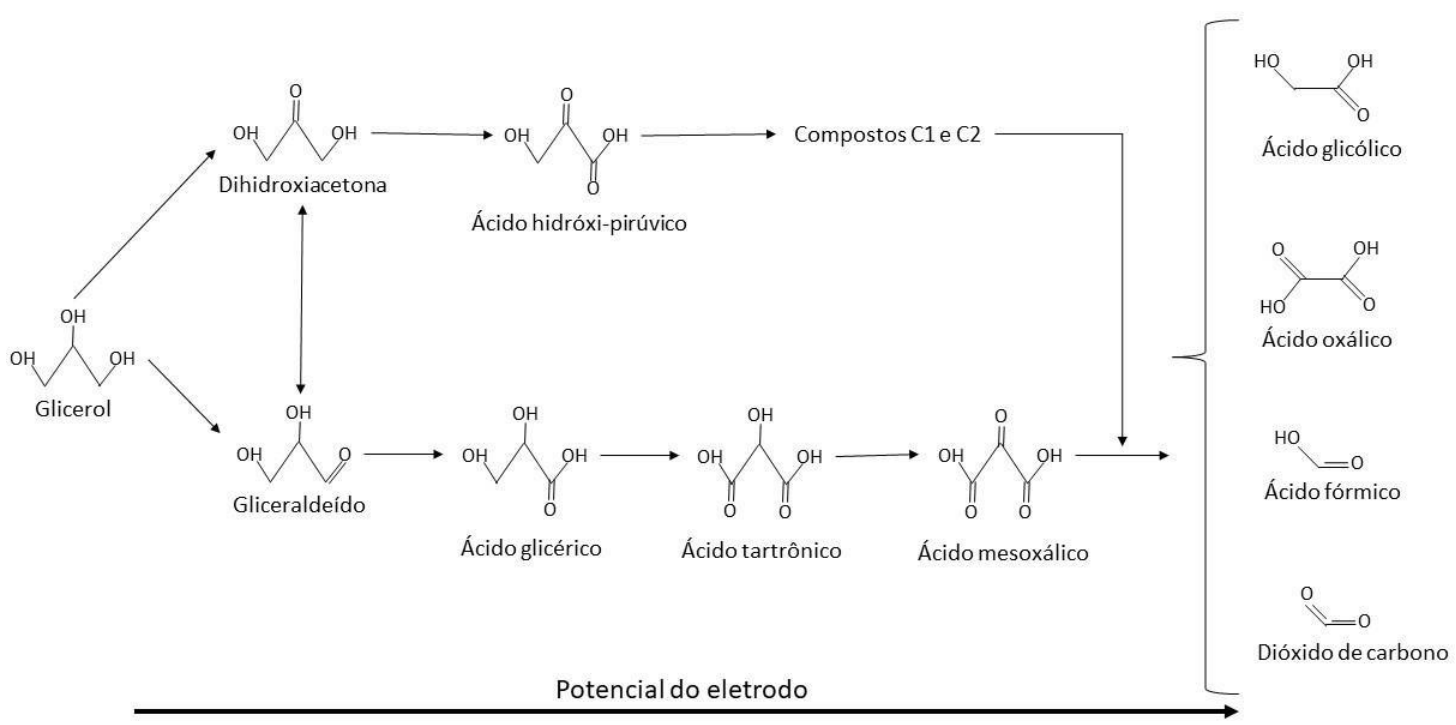

FONTE: Adaptado de (ARAUJO,2013; COUTANCEAU et al., 2019).

Como é possível observar (Figura 3), em baixos potenciais o principal produto formado é o gliceraldeído e conforme se aumenta o potencial aplicado novos produtos são gerados, como o ácido glicérico, ácido fórmico, ácido glicólico, ácido oxálico e até mesmo dióxido de carbono (potenciais maiores que 1,1 V). COUTANCEAU, BARANTON E KOUAMÉ (2019) ainda descrevem a formação da dihidroxiacetona em baixos potenciais quando foi utilizado catalisadores bimetálicos a base de platina. 


\subsubsection{Catalisadores para a oxidação eletroquímica do glicerol}

A Reação de Oxidação do Glicerol (GOR) está sendo estudada em meio ácido e alcalino usando vários catalisadores. Entre os catalisadores para GOR, os catalisadores a base de platina são os mais extensivamente estudados, sendo descrito que a platina é o único metal que apresenta alta atividade para a reação de oxidação eletroquímica do glicerol em meio ácido (AHMAD et al., 2021; DIRECT LIQUID FUEL CELLS, 2021).

Vários estudos relatam a platina como um metal ativo na oxidação do glicerol em células a combustível, isso porque os sítios ativos na superfície do catalisador são capazes de adsorver fortemente o reagente para que a reação de oxidação possa ocorrer (DIRECT LIQUID FUEL CELLS, 2021). Contudo, assim como acontece na oxidação de outros álcoois, o número de sítios ativos permanece limitado e pode ser saturado pelos intermediários formados durante a reação (WANG et al., 2020).

GOMES et al. (2012) investigaram a oxidação eletroquímica do glicerol em monocristais de Pt e verificaram que o monóxido de carbono é intermediário da oxidação do glicerol adsorvido comum em Pt (111), Pt (100) e Pt (110) em meio ácido. Seus estudos foram realizados por voltametria cíclica e FTIR e observaram que superfícies de $\mathrm{Pt}(100)$ e $\mathrm{Pt}(110)$ favoreciam a quebra das ligações C-C-C e, consequentemente, as intensidades relativas as bandas de produção de $\mathrm{CO}_{2} \mathrm{e}$ compostos com grupo carbonila (gerados pela oxidação parcial do glicerol) foi muito maior para Pt (100) e Pt (110) do que para Pt (111).

As propriedades estruturais e eletrônicas do catalisador podem ajudar na disposição dos elétrons que controlam as reações químicas resultando em uma oxidação do glicerol mais eficaz em superfícies bimetálicas em comparação com nanopartículas monometálicas (DIAS, 2009). Estudos recentes revelaram que catalisadores bimetálicos mostram não apenas as propriedades dos metais individuais como também criam novas propriedades, provenientes dos efeitos sinérgicos entre os metais utilizados (ZANATA, 2016). A atividade dos eletrocatalisadores também pode ser aumentada por modificações em sua superfície, forma, suportes dos catalisadores, geometria, morfologia ou composição 
de eletrocatalisadores bi ou multimetálicos, uma vez que são mais ativos, mais seletivos e menos propensos a desativação do que eletrocatalisadores monometálicos (RAHIM et al., 2020).

Dentre os metais utilizados como co-catalisador em materiais bimetálicos o ródio é um candidato potencial por possuir orbitais $d$ não preenchidos que podem efetivamente promover a clivagem da ligação $\mathrm{C}-\mathrm{C}$ em menor potencial de oxidação, além de ser um metal que exibe uma tolerância maior contra a corrosão irreversível e a dissolução no meio reacional (WANG et al., 2020).

ARAUJO (2013) estudou a eletro-oxidação do glicerol sob eletrodos de Pt e PtRh, variando a temperatura e a composição dos catalisadores, em meio ácido por voltametria cíclica (VC) e FTIR. Foi verificado que o aumento da temperatura favorece a atividade catalítica dos catalisadores bimetálicos e que o aumento de ródio até $10 \%$ aumenta os processos em todas as temperaturas. Além disso os resultados de FTIR mostraram que o acréscimo de ródio ao catalisador de Pt melhora a seletividade da reação à produção de $\mathrm{CO}_{2}$ tanto em função do potencial quanto em função do tempo.

Portanto, a presente pesquisa estudou 0 desenvolvimento de nanopartículas de $\mathrm{Pt}$ e de PtRh com orientação preferencial na direção (100) suportadas em carbono (eletrocatalisadores $\mathrm{Pt} / \mathrm{C}$ e $\mathrm{PtRh} / \mathrm{C}$ ) e avaliou a atividade desses eletrocatalisadores para a oxidação eletroquímica do etanol e glicerol em meio ácido. 


\section{MATERIAIS E MÉTODOS}

\subsection{Síntese das nanopartículas de $\mathrm{Pt} / \mathrm{C}$ (20\% em massa de $\mathrm{Pt})$ e $\mathrm{PtRh} / \mathrm{C}$ ( 20\% em massa de metais e razão atômica Pt:Rh de 95:5) com orientação preferencial na direção (100) suportadas em carbono (eletrocatalisadores $\mathrm{Pt} / \mathrm{C}$ e PtRh/C)}

A síntese dos eletrocatalisadores $\mathrm{Pt} / \mathrm{C}$ e $\mathrm{PtRh} / \mathrm{C}(20 \%$ em massa de metais) foi realizada pelo método da redução por álcool desenvolvido no IPENCNEN/SP por OLIVEIRA NETO et al., (2013); SPINACÉ et al., (2016) conforme ilustrado na Figura 4. Inicialmente, diluiu-se o ácido cloroplatínico (1 g $\mathrm{H}_{2} \mathrm{PtCl}_{6} .6 \mathrm{H}_{2} \mathrm{O}$ em $20 \mathrm{~mL}$ de $\mathrm{H}_{2} \mathrm{O}$ ) e o cloreto de ródio (250 mg RhCl em $50 \mathrm{~mL}$ de $\mathrm{H}_{2} \mathrm{O}$ ) fazendo uma solução padrão. A síntese envolveu dispersar as quantidades previamente calculadas dos precursores metálicos em $50 \mathrm{~mL}$ deuma solução etileno glicol/água (3:1 em volume) que continha $160 \mathrm{mg}$ de carbono (Vulcan XC72 - Cabot). O brometo de potássio (KBr) foi utilizado como agente direcionador na proporção atômica 300/1 (Br-/Pt). Essa mistura permaneceu 30 minutos no banho ultrassônico antes de ser submetida a refluxo térmico $\left(150^{\circ} \mathrm{C}\right)$ por $3 \mathrm{~h}$, sob constante agitação magnética. Após esse processoa mistura foi filtrada, lavada com água ultrapura em excesso e seca até se obter um pó catalítico Pt/C e PtRh/C, o qual foram realizadas as caracterizações físicoquímicas e eletroquímicas. Para finalidade de comparação, foram desenvolvidos eletrocatalisadores sem direcionamento de estrutura (sem $\mathrm{KBr}$ ) além daqueles com orientação preferencial. A razão atômica entre $\mathrm{Pt}: \mathrm{Rh}$ estudada foi de 95:5 (DIAS, 2009; ARAUJO, 2013). 
Figura 4 - Fluxograma das sínteses realizadas no trabalho.

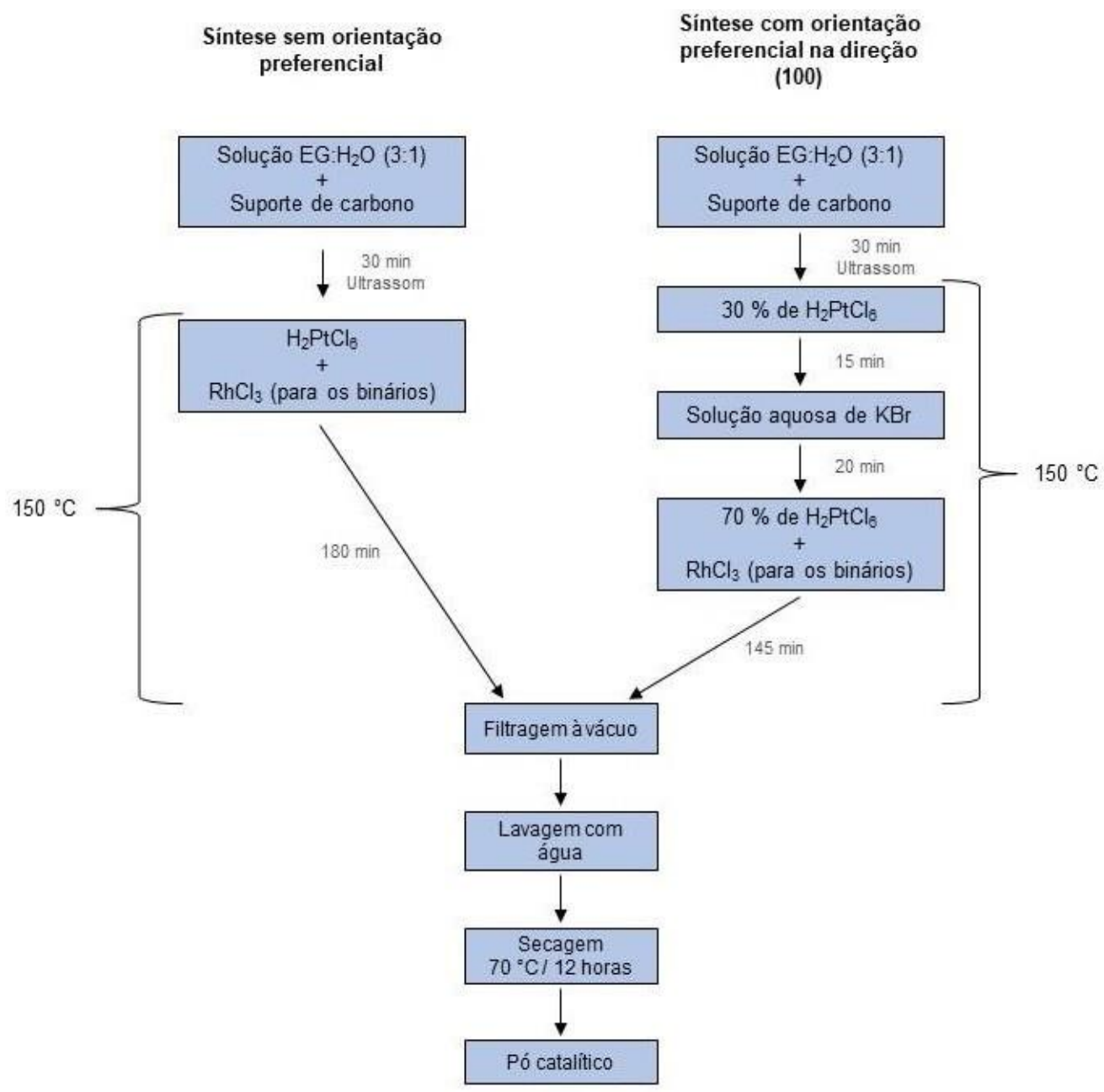

Fonte: Resultado da pesquisa.

\subsection{Caracterização físico-química dos eletrocatalisadores}

Um Microscópio Eletrônico de Transmissão (TEM - JEOL JEM 2100, operando a $200 \mathrm{~kW}$ ) foi utilizado para avaliar o tamanho, morfologia e distribuição das nanopartículas de Pt e PtRh suportadas em carbono. O tamanho das partículas foi registrado com base no diâmetro ou no tamanho de ponta a ponta de cada particulado, utilizando o softoware ImageJ. As intensidades dos picos de difração de raio-X (DRX) foram verificadas com um difratômetro Rigaku, modelo Miniflex, dotado de radiação CuKa $(\lambda=1,54056 \AA)$ no intervalo angular $2 \theta$ de $20^{\circ}$ a $90^{\circ}$, com velocidade de varredura de $2^{\circ} \min ^{-1}$, sendo o tamanho médio de cristalito estimado a partir da equação de Scherrer. A determinação dos constituintes atômicos foi 
realizada utilizando análises de energia dispersiva de raio-X (EDX) por meio de um microscópio eletrônico de varredura Philips XL 30, com feixe de elétrons operando a $20 \mathrm{keV}$.

\subsection{Caracterização eletroquímica}

Os materiais foram avaliados eletroquimicamente frente a reação de oxidação do etanol por meio das técnicas de voltametria cíclica (VC) e cronoamperometria usando um potenciostato/galvanostato Metrohm Autolab PGSTAT 302N. Os experimentos foram conduzidos em uma célula de três eletrodos. Como contra-eletrodo e eletrodo de referência foram usados um fio de platina e o Eletrodo Padrão de Hidrogênio (HRE), respectivamente. Como eletrodo de trabalho utilizou-se um eletrodo de camada ultrafina porosa de carbono vítreo com $5 \mathrm{~mm}$ de diâmetro. A tinta do catalisador foi preparada da seguinte forma: $10 \mathrm{mg}$ de catalisador foi disperso em 1,8 $\mathrm{ml}$ de água, 1,2 $\mathrm{ml}$ de álcool isopropílico e $50 \mu \mathrm{L}$ de solução de Nafion (5\%). Essa tinta permaneceu por 30 minutos no banho ultrassônico para garantir total homogeneização. No carbono vítreo do eletrodo de trabalho foi depositado $20 \mu \mathrm{L}$ dessa tinta, seca com auxílio de uma lâmpada aquecedora. Como eletrólito, foi utilizada uma solução de ácido sulfúrico0,5 mol L ${ }^{-1}$ e para os testes na presença de combustível utilizou-se uma solução 1,0 $\mathrm{mol} \mathrm{L}{ }^{-1}$ de etanol. Antes e durante a realização dos experimentos eletroquímicos, nitrogênio ultrapuro foi borbulhado com intuito de remover o oxigênio presente no eletrólito. Para os experimentos de stripping de $\mathrm{CO}$ o eletrodo de trabalho foi polarizado em 0,25 V e monóxido de carbono (CO) foi borbulhado ao eletrólito durante 15 minutos, seguido de $\mathrm{N}_{2}$ por 30 minutos. A velocidade de varredura escolhida para o registro das VCs foi de $50 \mathrm{mV} \mathrm{s}^{-1}$, sendo todos os testesrealizados a temperatura ambiente. Os testes foram realizados em duplicata e os resultados apresentados são a média dos dois testes. As densidades de corrente foram normalizadas pela área eletroquimicamente ativa de platina, calculadas a partir dos voltamogramas cíclicos de cada catalisador, por meio da seguinteexpressão (XING, 2005; ANTONIASSI, 2017):

$$
\text { área eletroquimicamente ativa } P t=\frac{Q}{[P t] \cdot q H}
$$


onde $\mathrm{Q}$ correspondente a carga referente à integral da área de dessorção de hidrogênio no intervalo de 0,05 - 0,4 V; [Pt] a massa de metal utilizado (em mg) e $q H$ a carga de dessorção de uma monocamada de hidrogênio sobre a platina (210

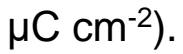

\subsection{Ensaios em célula a combustível do tipo DEFC e DGFC}

Uma célula unitária de $5 \mathrm{~cm}^{2}$ de área geométrica foi utilizada para a realização dos experimentos. A temperatura de célula estabelecida foi de $60{ }^{\circ} \mathrm{C}$ e a do umidificador de oxigênio (utilizado no cátodo da célula) foi de $80^{\circ} \mathrm{C}$. O fluxo de combustível aplicado foi de $1 \mathrm{~mL} / \mathrm{min}$ e o fluxo de oxigênio de $300 \mathrm{~mL} / \mathrm{min}$. As soluções utilizadas como combustível foram preparadas com água ultrapura nas concentrações de $2 \mathrm{~mol} / \mathrm{L}$ de etanol e $1 \mathrm{~mol} / \mathrm{L}$ de glicerol. Para realização das medidas utilizou-se o potenciostato/galvanostato PGSTAT 302 N Autolab.

\subsubsection{Preparação do conjunto eletrodo-membrana-eletrodo (MEA)}

Para a confecção de todos os conjuntos MEA utilizou-se um tecido de carbono teflonado com $5 \mathrm{~cm}^{2}$ de área. Como membrana de troca catiônica foi usada a membrana de Nafion N117 da DuPont. A camada catalítica dos eletrodos foi preparada utilizando solução de Nafion (dispersão 5\% DE520 da DuPont), álcool isopropílico e $1 \mathrm{mg} / \mathrm{cm}^{2}$ de eletrocatalisadores, sendo o ânodo confeccionado com os eletrocatalisadores aqui estudados e no cátodo catalisador comercial Pt/C 20\% em massa da Basf.

A camada catalítica preparada foi transferida para o tecido de carbono com auxílio de um pincel. Após total transferência da carga catalítica os eletrodos foram colocados em estufa a $70{ }^{\circ} \mathrm{C}$, por um período de 24 horas, para secagem. Depois desse processo os eletrodos previamente preparados foram prensados junto à membrana de Nafion. Para isso foram usadas chapas de aço, onde foi colocado um espaçador, o eletrodo anódico com a camada catalítica voltada para cima, a membrana colocada sobre o ânodo, o eletrodo catódico colocado com a camada catalítica voltada para baixo e por fim o outro espaçador. 
A prensa foi ligada a uma temperatura de $105^{\circ} \mathrm{C}$. Quando atingindo essa temperatura as chapas de aço com o MEA foram colocadas na prensa, então ela foi fechada até encostar as placas, logo alterou-se a temperatura para $125^{\circ} \mathrm{C}$. Ao atingir essa temperatura foi aplicada uma pressão que corresponde a 5 toneladas por um tempo de 5 minutos.

\subsection{Análise de espectrometria de massas diferencial (DMS)}

Para a análise do perfil químico dos produtos formados nos diferentes potenciais, a saída do sistema das células DEFC e DGFC foram acopladas a um espectrômetro de massas diferencial (DMS) da marca Pfeiffer Vaccum HiCube, equipado com um multiplicador de elétron secundário de dínodo contínuo/detector de copo de Faraday MID (Multiple Ion Detection). O fluxo da válvula de segurança foi ajustado em 120, sendo o fluxo da amostra de $1 \mathrm{~mL} / \mathrm{min}$ nas células. $\mathrm{Na}$ janela de detecção, foram elencados os íons relativos aos produtos parciais da oxidação de etanol e de glicerol que foram obtidos, simultaneamente, em cada variação de potencial, no experimento de VC. O tempo de leitura para cada íon no espectrômetro de massas foi de 5 minutos, utilizando velocidade de 200 miliscans (200ms) por íon, de forma simultânea. Uma válvula de dosagem de gás (evn 116, Pfeiffer) conectou as duas câmaras e a interface Reator/DEMS que estava no topo da câmara de vácuo primária, separada por uma membrana de PTFE (poli-tetraflúor-etileno) de tamanho poroso de $200 \mu \mathrm{m}$ (Whatman®) em fluxo contínuo e monitorando por detecção de íons múltiplos pelo software QUADERA®.

\subsection{Espectroscopia na região do infravermelho com Transformada de Fourier e Refletância Total Atenuada (ATR-FTIR)}

Os efluentes dos intervalos de potenciais escolhidos para estudo foram coletados por cinco minutos, e todas as amostras foram analisadas por ATR-FTIR utilizando um equipamento Nicolet@ 6700, equipado com detector MCT refrigerado por nitrogênio líquido, usando acessório ATR (MIRacle com placa de cristal ZnSe Pike®) e programa OMNIC8 (Thermo), para aquisição dos espectros. O número de varreduras operadas foi de 32ms. A janela de análise foi de 800 a 1500 wavenumber $\mathrm{cm}^{-1}$, AutoGain e resolução igual a 8, apodização no modo HAPP. Os 
espectros de absorbância foram coletados usando água como espectro de fundo (background). Os dados foram exportados como ASCII para o programa Origin para análises de processamento e interpretação. 


\section{$5 \quad$ RESULTADOS E DISCUSSÃO}

\subsection{Composição atômica nominal e experimental (EDX)}

$\mathrm{Na}$ Tabela 1 são apresentados os resultados obtidos pela técnica de EDX da composição química dos eletrocatalisadores $\mathrm{Pt} / \mathrm{C}$ e $\mathrm{PtRh} / \mathrm{C}$ policristalinos sintetizados pelo método de redução por álcool e dos eletrocatalisadores $\mathrm{Pt} / \mathrm{C}$ (100) e $\mathrm{PtRh} / \mathrm{C}$ (100) preparados com orientação preferencial de estrutura cristalina na direção (100).

Tabela 1 - Composição química dos eletrocatalisadoes obtida pela técnica EDX (20\% em massa de metais e razão atômica Pt:Rh de 95:5).

\begin{tabular}{c|c|c}
\hline Eletrocatalisador & \% Massa Metal (EDX) & $\begin{array}{c}\text { Razão } \\
\text { atômica } \\
\text { Pt:Rh (EDX) }\end{array}$ \\
\hline $\mathrm{Pt} / \mathrm{C}$ & 20 & - \\
$\mathrm{Pt} / \mathrm{C}(100)$ & 21 & - \\
$\mathrm{PtRh} / \mathrm{C}$ & 23 & $95: 5$ \\
\hline $\mathrm{PtRh} / \mathrm{C}(100)$ & 24 & $94,5: 5,5$ \\
\hline
\end{tabular}

Fonte: Resultado da pesquisa.

Os resultados obtidos por EDX de forma semi-quantitativa apresentaram valores bem próximos aos nominais (20\% em massa de metal e 95:5 razão entre PtRh) para o percentual em massa de metais e para a razão atômica Pt:Rh, indicando que os métodos utilizados são adequados para a preparação dos eletrocatalisadores. Além disso, vale ressaltar que durante a análise dos materiais com direcionamento de estrutura cristalina, não foram observados traços de $\mathrm{KBr}$ nas análises realizadas, mostrando que o processo de lavagem com água utilizado para a remoção do agente direcionador é bastante simples e efetivo em sua remoção. 


\subsection{Microscopia eletrônica de transmissão (MET)}

Na Figura 5a é apresentada a micrografia eletrônica de transmissão para o eletrocatalisador Pt/C (100) e a Figura 5b exibe um histograma com a distribuição do tamanho das nanopartículas.

Figura 5 - a) Micrografia do eletrocatalisador Pt/C (100) e b) histograma com a distribuição do tamanho das nanopartículas.
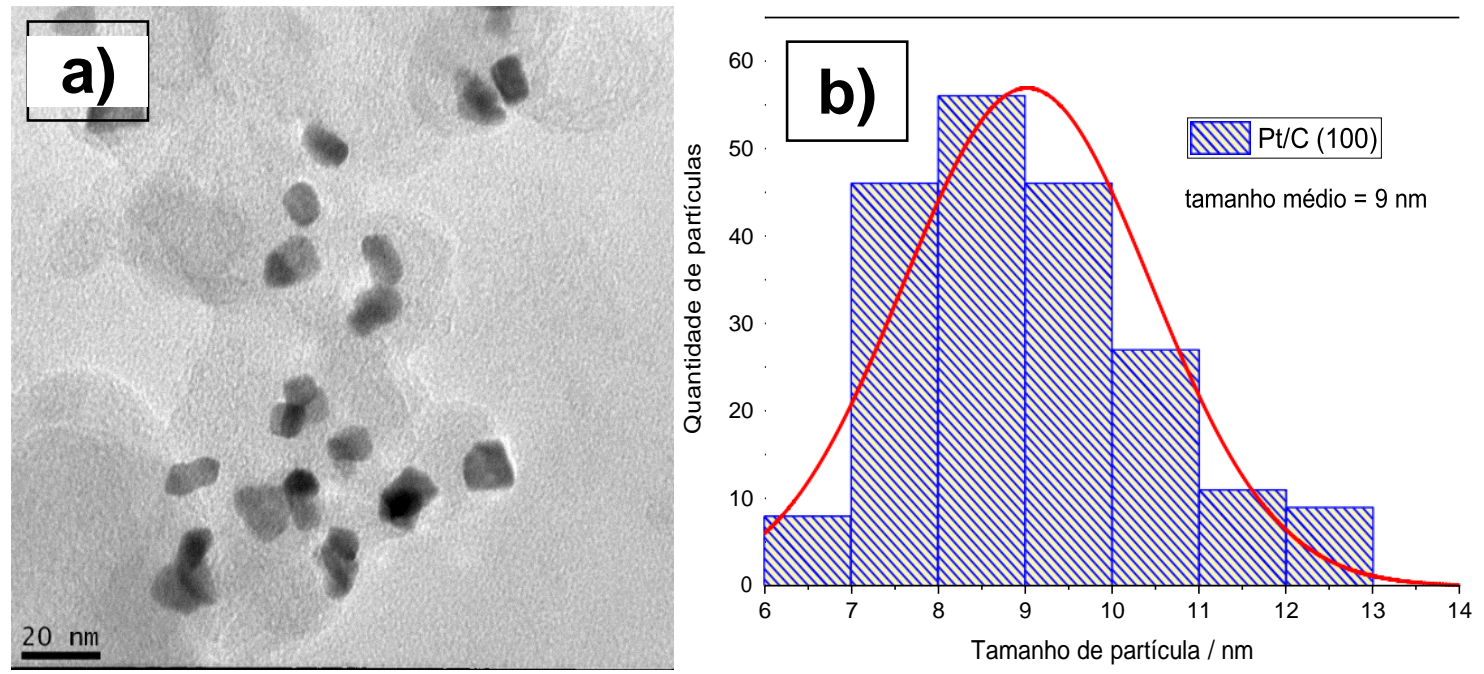

Fonte: Resultado da pesquisa.

Pela Figura 5a observamos claramente que a maioria das nanopartículas de Pt possuem morfologia cúbica e encontram-se bem dispersas sobre o suporte de carbono. O histograma (Figura 5b) mostra um tamanho médio de $9 \mathrm{~nm}$ para o eletrocatalisador Pt/C (100) sintetizado pelo método de redução por álcool utilizando $\mathrm{KBr}$ como agente direcionador de estrutura. É exibido na Figura 6a a micrografia eletrônica de transmissão para o eletrocatalisador PtRh/C (100) e na Figura 6b o histograma com a distribuição do tamanho das nanopartículas. 
Figura 6 - a) Micrografia do eletrocatalisador PtRh/C (100) e b) histograma com a distribuição do tamanho das nanopartículas.
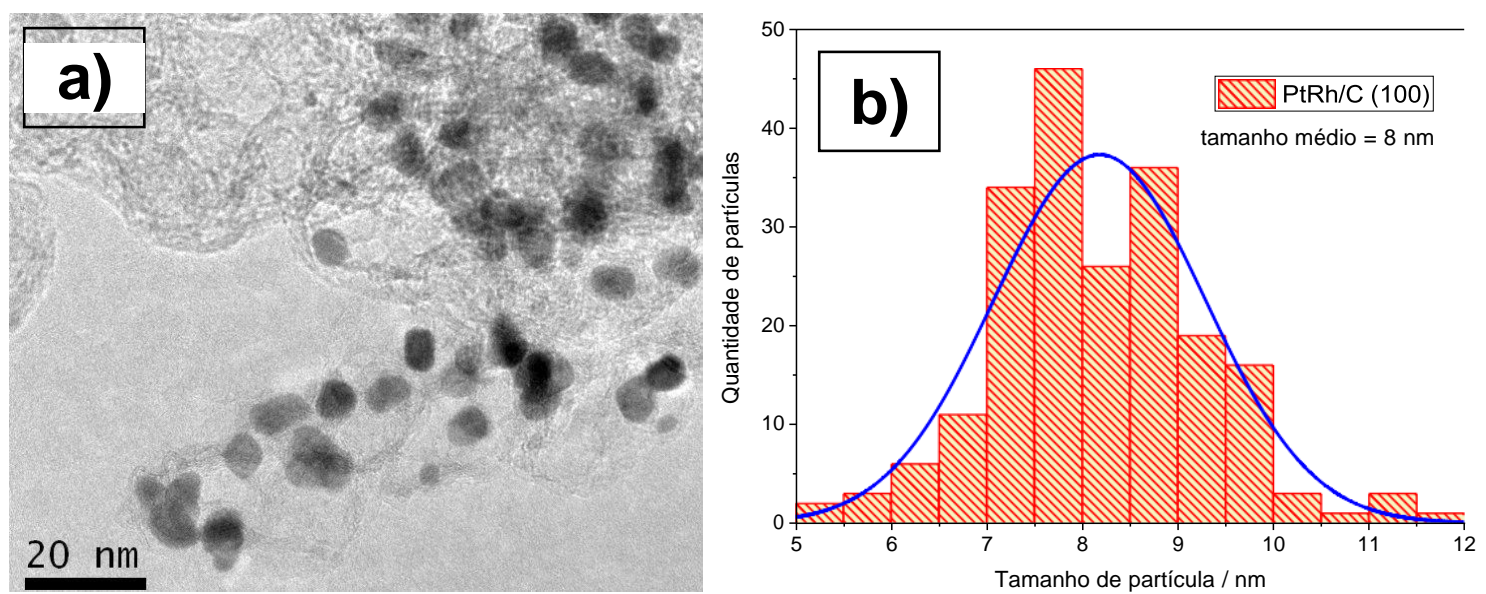

Fonte: Resultado da pesquisa.

Pela Figura 6a também pode-se observar que a maioria das nanopartículas possui a morfologia cúbica além de apresentarem uma boa dispersão sobre o suporte de carbono. O histograma (Figura 5b) apresenta um tamanho médio das nanopartículas de $8 \mathrm{~nm}$ para o eletrocatalisador PtRh/C (100) bem próximo ao do eletrocatalisador Pt/C (100) que apresentou um tamanho médio de $9 \mathrm{~nm}$.

\subsection{Difração de raios $X(D R X)$}

Os difratogramas de raios $X$ para os eletrocatalisadores $\mathrm{Pt} / \mathrm{C}, \mathrm{PtRh} / \mathrm{C}$, $\mathrm{Pt} / \mathrm{C}$ (100) e PtRh/C (100) são apresentados na Figura 7. Na Tabela 2 são apresentados as estimativas dos tamanhos de cristalitos obtidos pela Equação de Scherrer e os valores de intensidade relativa dos picos $\mathrm{Pt}_{(111)} / \mathrm{Pt}_{(200)}$. 
Figura 7 - Difratogramas de raios X para os eletrocatalisadores Pt/C, Pt/C (100), PtRh/C e $\mathrm{PtRh} / \mathrm{C}$ (100) sintetizados pelo método de redução por álcool.
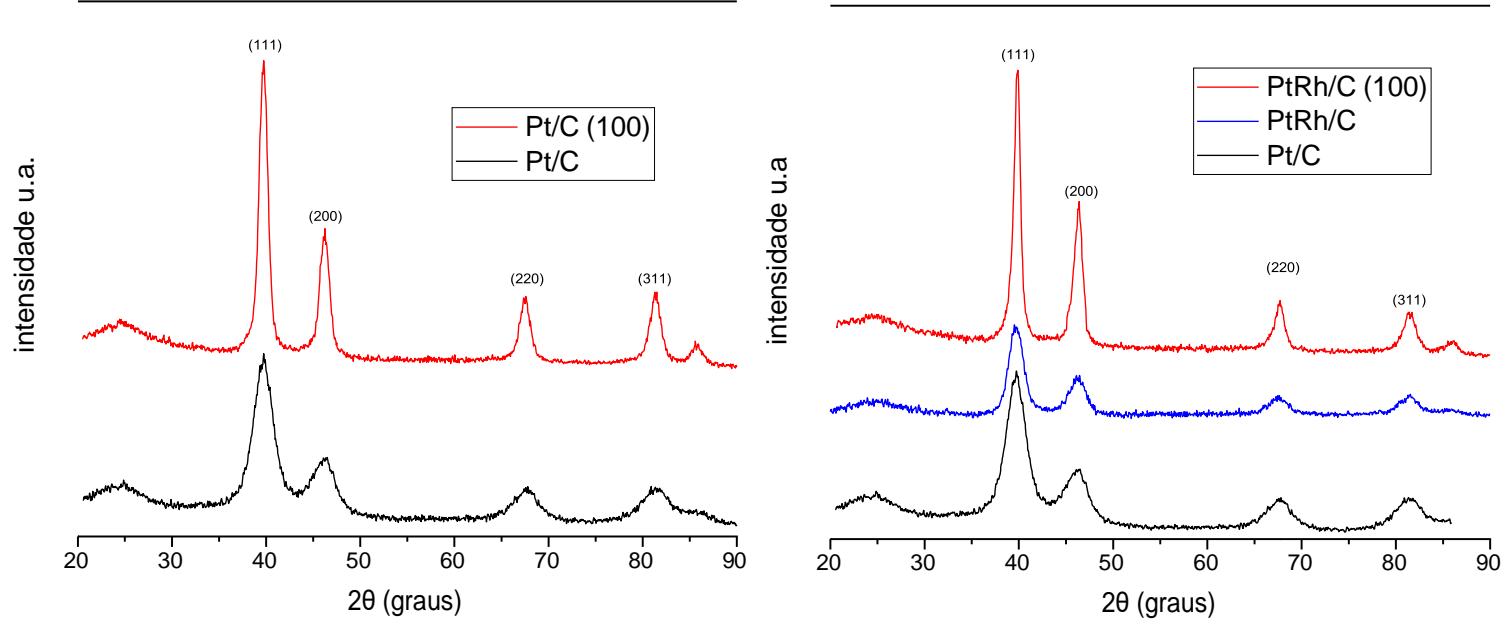

Fonte: Resultado da pesquisa.

A partir da Figura 7 se observa que todos os difratogramas exibem um pico largo em $2 \theta \cong 25^{\circ}$ referente ao suporte de carbono utilizado na síntese, assim como os picos em $2 \theta \cong 40^{\circ}, 47^{\circ}, 67^{\circ}$ e $82^{\circ}$, referentes respectivamente aos planos (111), (200), (220) e (311) característicos às estruturas cúbicas de face centrada (CFC) da Pt, Rh e das ligas de PtRh (SHEN et. al., 2010). É interessante notar que a razão entre as intensidades dos picos $\mathrm{Pt}(111) / \mathrm{Pt}(200)$ dos difratogramas (Tabela 2) é de aproximadamente 2,3 para $\mathrm{Pt} / \mathrm{C}$ e $\mathrm{PtRh} / \mathrm{C}$ e de aproximadamente 1,5 para $\mathrm{Pt} / \mathrm{C}$ (100) e PtRh/C (100), indicando que os materiais preparados com orientação preferencial tem domínios Pt (100) mais abundantes que os eletrocatalisadores sem orientação (ANTONIASSI 2017).

Além disso, é observado que os picos (220) dos eletrocatalisadores $\mathrm{PtRh} / \mathrm{C}$ e PtRh/C (100), $2 \theta \cong 67^{\circ}$, apresentaram um leve deslocamento, para valores menores de $2 \theta$, quando comparados com o pico da $\mathrm{Pt} / \mathrm{C}$, inferindo uma possível formação de liga metálica entre Pt e Rh (SEN GUPTA e DATTA, 2006). 
Tabela 2 - Tamanho médio de cristalito ( $\mathrm{Pt} / \mathrm{C}$ e $\mathrm{PtRh} / \mathrm{C}$ ), tamanho médio de nanopartícula ( $\mathrm{Pt} / \mathrm{C}$ (100) e PtRh/C (100)) e intensidade relativa dos picos $\mathrm{Pt}(111) / \mathrm{Pt}(200)$ para os eletrocatalisadores estudados.

\begin{tabular}{c|c|c}
\hline Eletrocatalisador & $\begin{array}{c}\text { Tamanho de cristalito } \\
\text { e nanopartícula }(\mathbf{n m})\end{array}$ & $\begin{array}{c}\text { Intensidade relativa } \\
\text { dos picos de DRX } \\
\mathbf{P t}_{(111)} / \mathbf{P t}_{(\mathbf{2 0 0})}\end{array}$ \\
\hline $\mathrm{Pt} / \mathrm{C}$ & 3 & 2,3 \\
$\mathrm{PtRh} / \mathrm{C}$ & 3 & 2,3 \\
\hline $\mathrm{Pt} / \mathrm{C}(100)$ & 9 & 1,5 \\
\hline $\mathrm{PtRh} / \mathrm{C}(100)$ & 8 & 1,5 \\
\hline
\end{tabular}

Fonte: Resultado da pesquisa.

A partir dos difratogramas foi possível estimar o tamanho médio de cristalito (Tabela 2) sendo este aproxidamente $3 \mathrm{~nm}$ para os eletrocatalisadores policristalinos resultado similar aos relatados na preparação destes eletrocatalisadores pelo método da redução por álcool (FONTES, 2017; ANTONIASSI, 2017). Para os eletrocatalisadores preparados com orientação preferencial, Pt/C (100) e PtRh/C (100), estes valores foram de 9 e $8 \mathrm{~nm}$, respectivamente.

\subsection{Stripping de CO}

Aqui apresentamos os perfis voltamétricos da eletro-oxidação de uma monocamada de $\mathrm{CO}$ (stripping de $\mathrm{CO}$ ) dos materiais estudados. Para fins comparativos o eletrocatalisador $\mathrm{Pt} / \mathrm{C}$ comercial (Basf) foi incluído nos próximos estudos. A seguir são mostrados os resultados de stripping de $\mathrm{CO}$ para os eletrocatalisadores Pt/C Basf (Figura 8), Pt/C policristalino (Figura 9) e Pt/C (100) (Figura 10). 
Figura 8 - Experimento de stripping de $\mathrm{CO}$ do eletrocatalisador $\mathrm{Pt} / \mathrm{C}$ (Basf) realizado com velocidade de varredura de $50 \mathrm{mV} \mathrm{s}^{-1}$ em solução $0,5 \mathrm{~mol} \mathrm{~L}^{-1}$ de $\mathrm{H}_{2} \mathrm{SO}_{4}$.

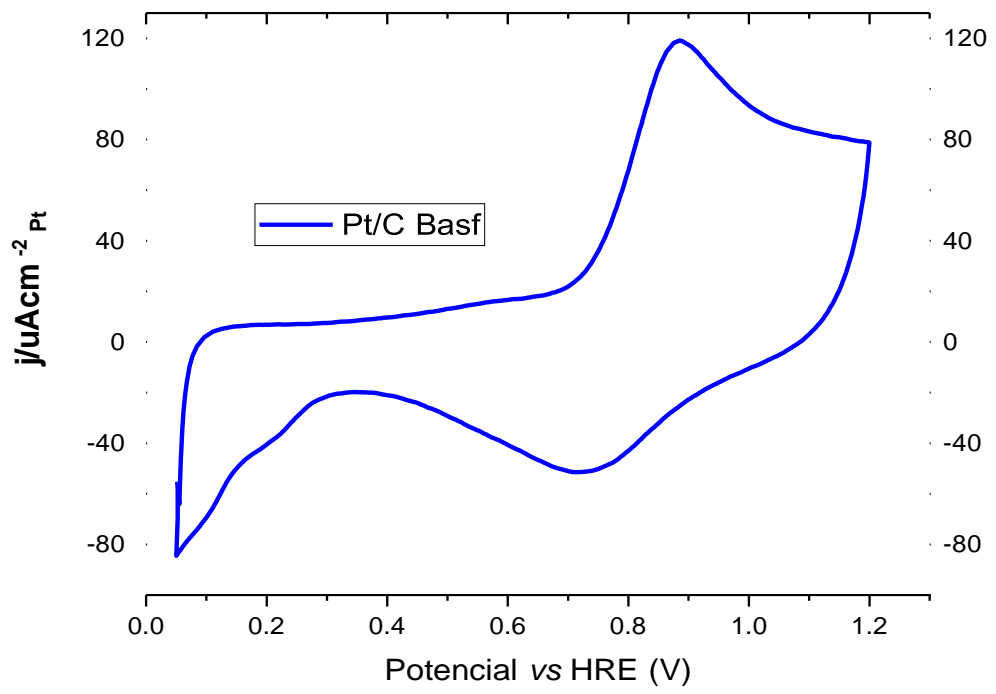

Fonte: Resultado da pesquisa.

Figura 9 - Experimento de stripping de $\mathrm{CO}$ do eletrocatalisador $\mathrm{Pt} / \mathrm{C}$ realizado com velocidade de varredura de $50 \mathrm{mV} \mathrm{s}^{-1}$ em solução $0,5 \mathrm{~mol} \mathrm{~L}^{-1}$ de $\mathrm{H}_{2} \mathrm{SO}_{4}$.

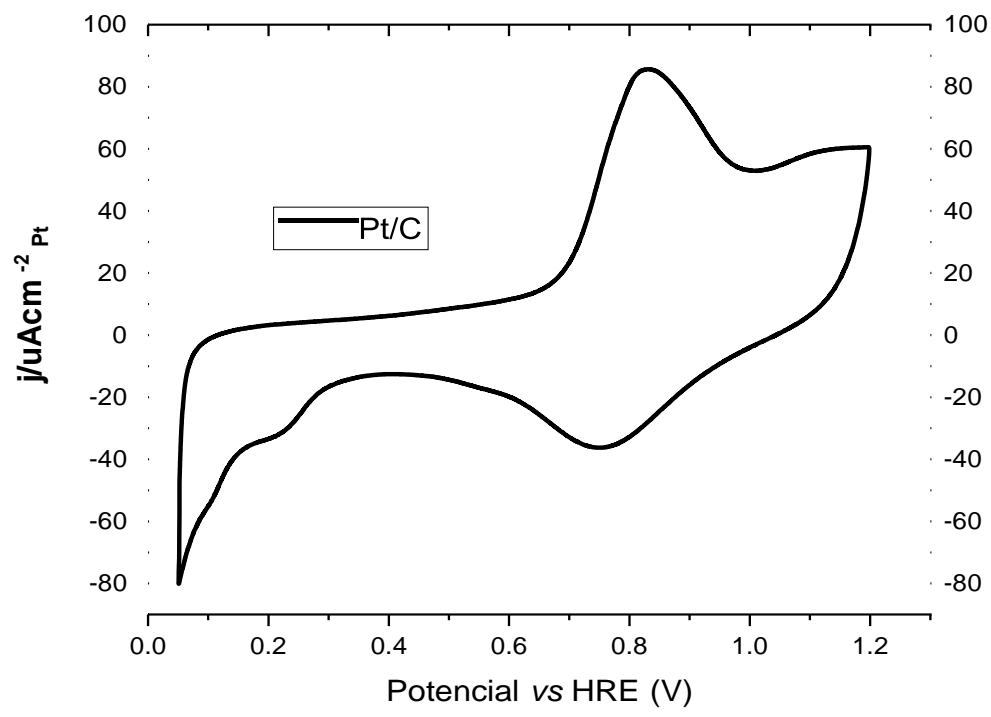

Fonte: Resultado da pesquisa. 
Figura 10 - Experimento de stripping de CO do eletrocatalisador Pt/C (100), sintetizado com orientação preferencial, realizado com velocidade de varredura de $50 \mathrm{mV} \mathrm{s}^{-1}$ em solução $0,5 \mathrm{~mol} \mathrm{~L}^{-1} \mathrm{de} \mathrm{H}_{2} \mathrm{SO}_{4}$.

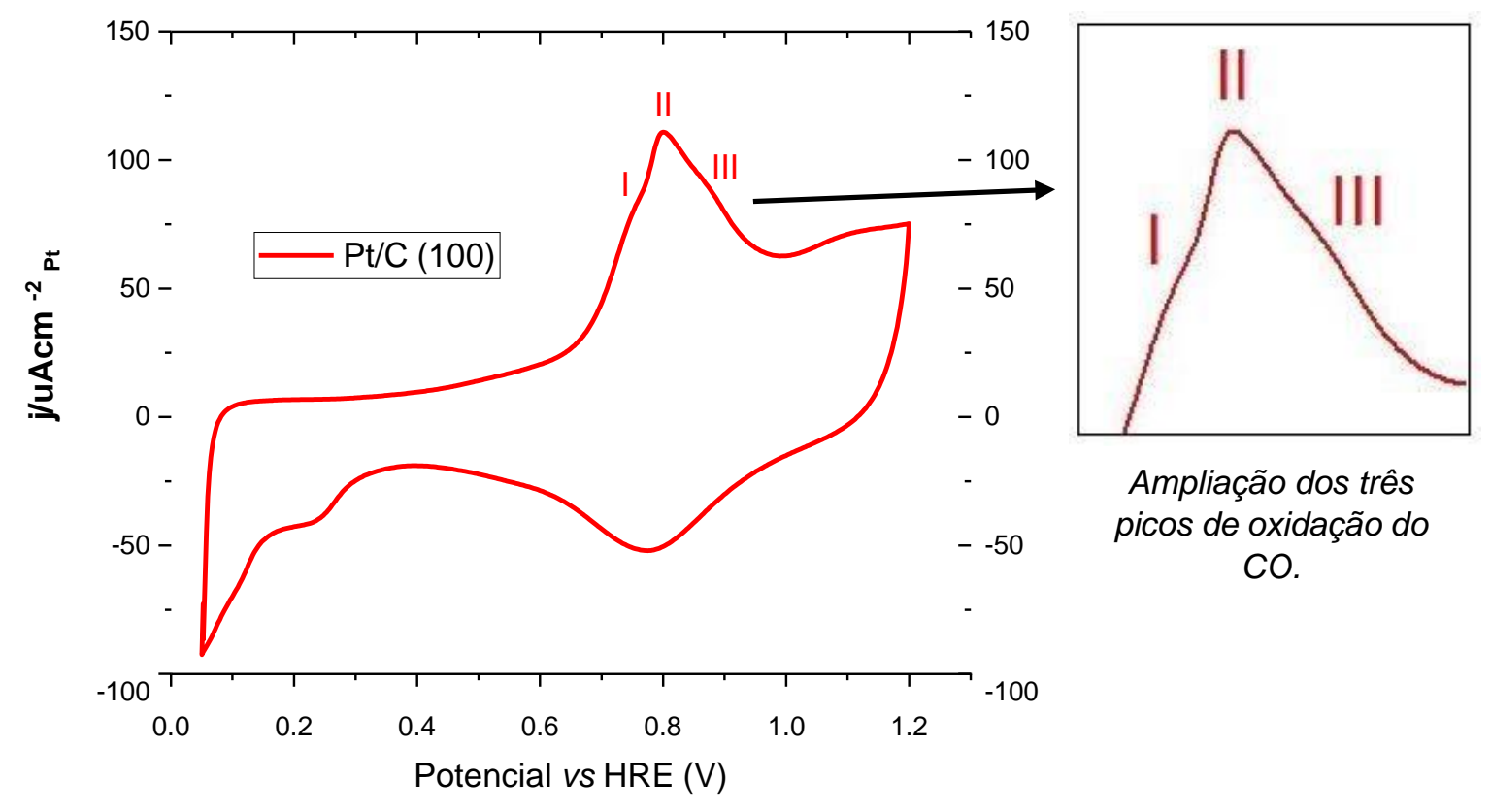

Fonte: Resultado da pesquisa.

A platina tem uma forte interação com o monóxido de carbono (CO), de tal maneira que o CO é uma molécula comumente utilizada para estudos de modificações superficiais na estrutura do metal (CONTANCEU et al., 2012; URCHAGA et al., 2013; CHEN et al., 2015). Como observado nas Figuras 8, 9 e 10 o perfil voltamétrico da eletro-oxidação de uma monocamada de CO (técnica de Stripping de CO) dos materiais sem orientação preferencial é diferente daquele do material preferencialmente cúbico Pt/C (100). O stripping de $\mathrm{CO}$ dos eletrocatalisadores Pt/C (Basf) e Pt/C apresentaram apenas um pico de oxidação, em aproximadamente $0,88 \mathrm{~V}$ e $0,83 \mathrm{~V}$ respectivamente, condizente com o descrito na literatura (URCHAGA et al., 2013; CHEN et al., 2015). Já para o Pt/C (100) são observados três picos para a mesma reação, em $\cong 0,75 \mathrm{~V}(\mathrm{I})$, $\cong 0,80 \mathrm{~V}$ (II) $\mathrm{e} \cong 0,86$ V (III). Geralmente essa divisão de picos é dependente da maneira como o CO adsorve no metal, ou seja, mudanças nas características dos sítios superficiais da Pt promovem diferentes perfis voltamétricos (YE et al., 2014). Assim, na presente pesquisa essa divisão dos picos pode estar associada ao aumento das superfícies planas existentes nos cubos preferencialmente formados no eletrocatalisador $\mathrm{Pt} / \mathrm{C}$ (100) (ANTONIASSI, 2017). 
Para os eletrocatalisadores a base de $\mathrm{PtRh}$ os resultados do experimento de stripping de CO são apresentados na Figura 11.

Figura 11 - Experimentos de stripping de $\mathrm{CO}$ dos eletrocatalisadores, $\mathrm{PtRh} / \mathrm{C}$ em a) e PtRh/C (100) em b), realizados com velocidade de varredura de $50 \mathrm{mV} \mathrm{s}^{-1} \mathrm{em}$ solução $0,5 \mathrm{~mol} \mathrm{~L}^{-1}$ de $\mathrm{H}_{2} \mathrm{SO}_{4}$.

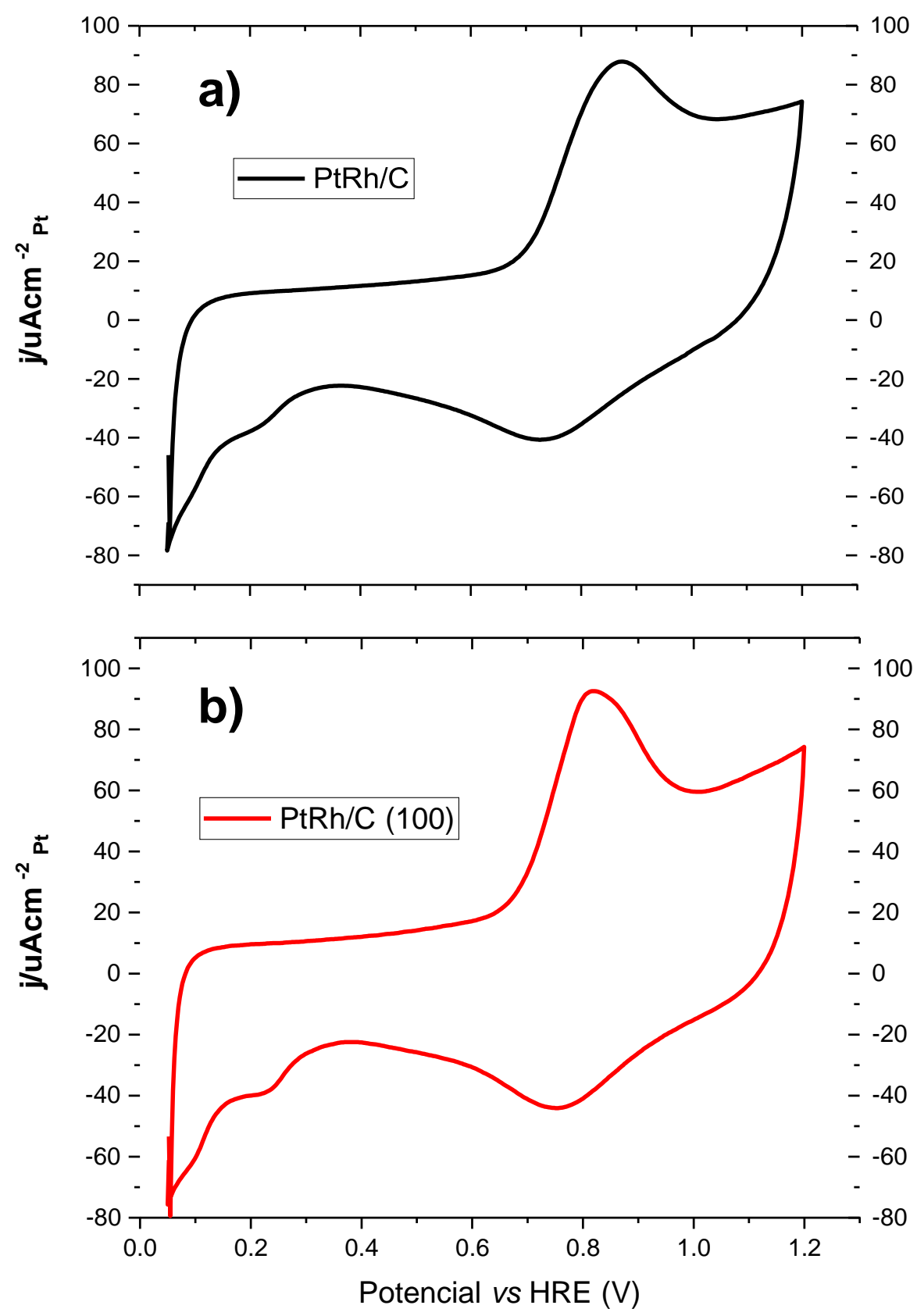

Fonte: Resultado da pesquisa.

Os resultados apresentados na Figura 11 sugerem que, para os materiais bi metálicos, o perfil voltamétrico da eletro-oxidação de uma monocamada 
de CO não apresentam diferenças relevantes em relação à formação dos picos de oxidação, uma vez que em ambos eletrocatalisadores apenas um único pico de oxidação é visível. Porém para o eletrocatalisador PtRh/C (100) (Figura 11b) o pico da reação de oxidação se dá em aproximadamente $0,80 \mathrm{~V}$, enquanto que para o PtRh/C (Figura 11a) esse pico está em 0,87 V. Estudos mostraram que a oxidação do $\mathrm{CO}$ em superfícies planas acontece em menores potenciais, enquanto que nos sítios das bordas e/ou quinas ocorrem em potenciais mais elevados (YE et al., 2014). Dessa forma, acredita-se que o menor valor de oxidação observado para o material PtRh/C (100) está ligado ao aumento das superfícies planas existentes nas nanopartículas com formação preferencialmente cúbicas. Por outro lado, 0 eletrocatalisador $\mathrm{PtRh} / \mathrm{C}$ apresenta maior potencial de oxidação pela superfície irregular das nanopartículas do material sem orientação preferencial.

\subsection{Voltametria cíclica em meio ácido}

O comportamento eletroquímico geral dos catalisadores foi obtido por voltametria cíclica em solução ácida de $\mathrm{H}_{2} \mathrm{SO}_{4}\left(0,5 \mathrm{~mol} \mathrm{~L}^{-1}\right)$, a uma velocidade de varredura de $50 \mathrm{mV} \mathrm{s}^{-1}$, no intervalo de potencial de 0,05 a 0,8 V. Os voltamogramas adquiridos em meio ácido para os materiais $\mathrm{Pt} / \mathrm{C}$ (Basf) comercial e Pt/C sintetizado sem orientação preferencial estão apresentados nas Figuras 12 e 13. Para o eletrocatalisador Pt/C (100) o perfil voltamétrico em meio ácido é mostrado na Figura 14. 
Figura 12 - Voltamograma cíclico do eletrocatalisador Pt/C (Basf) em solução 0,5 mol L-1 de $\mathrm{H}_{2} \mathrm{SO}_{4}$ com velocidade de varredura de $50 \mathrm{mV} \mathrm{s}^{-1}$.

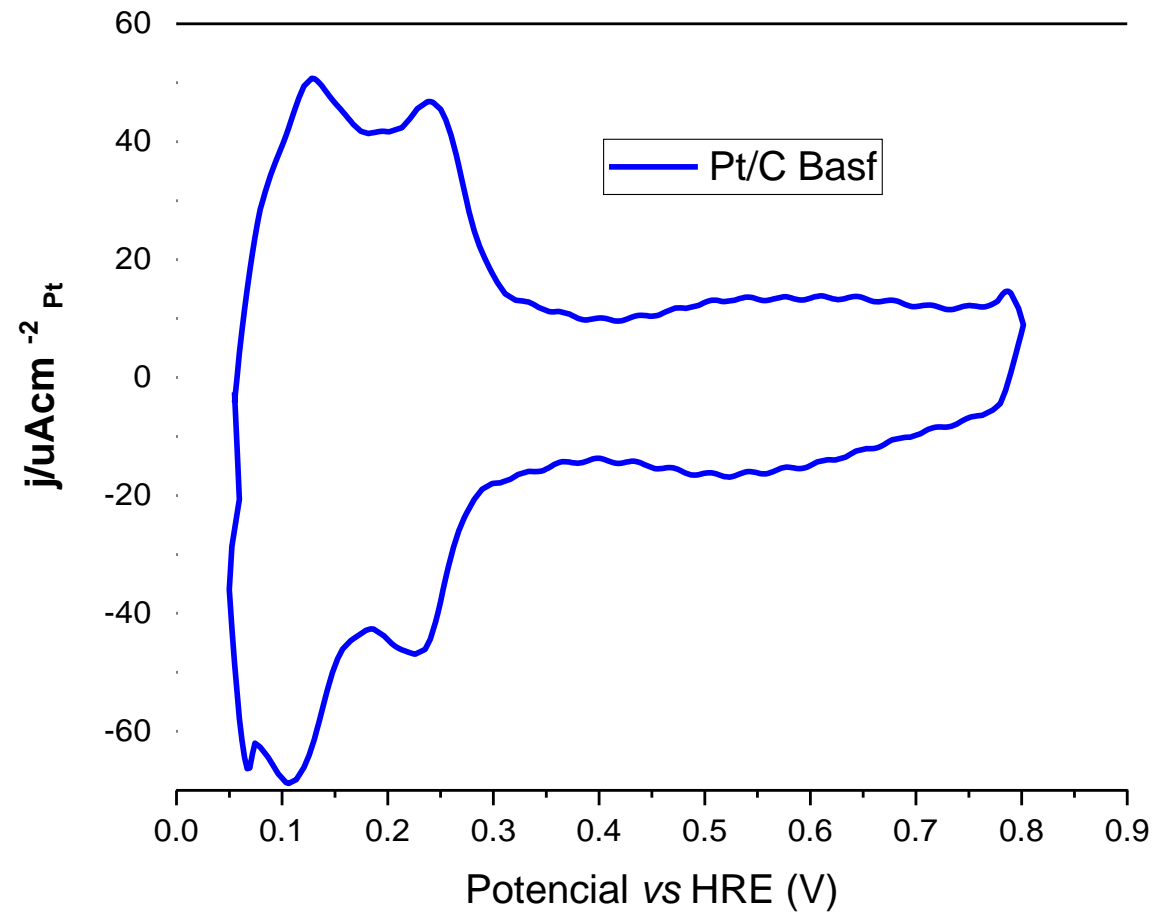

Fonte: Resultado da pesquisa.

Figura 13 - Voltamograma cíclico do eletrocatalisador Pt/C em solução $0,5 \mathrm{~mol} \mathrm{~L}^{-1} \mathrm{de}_{2} \mathrm{SO}_{4}$ com velocidade de varredura de $50 \mathrm{mV} \mathrm{s}^{-1}$.

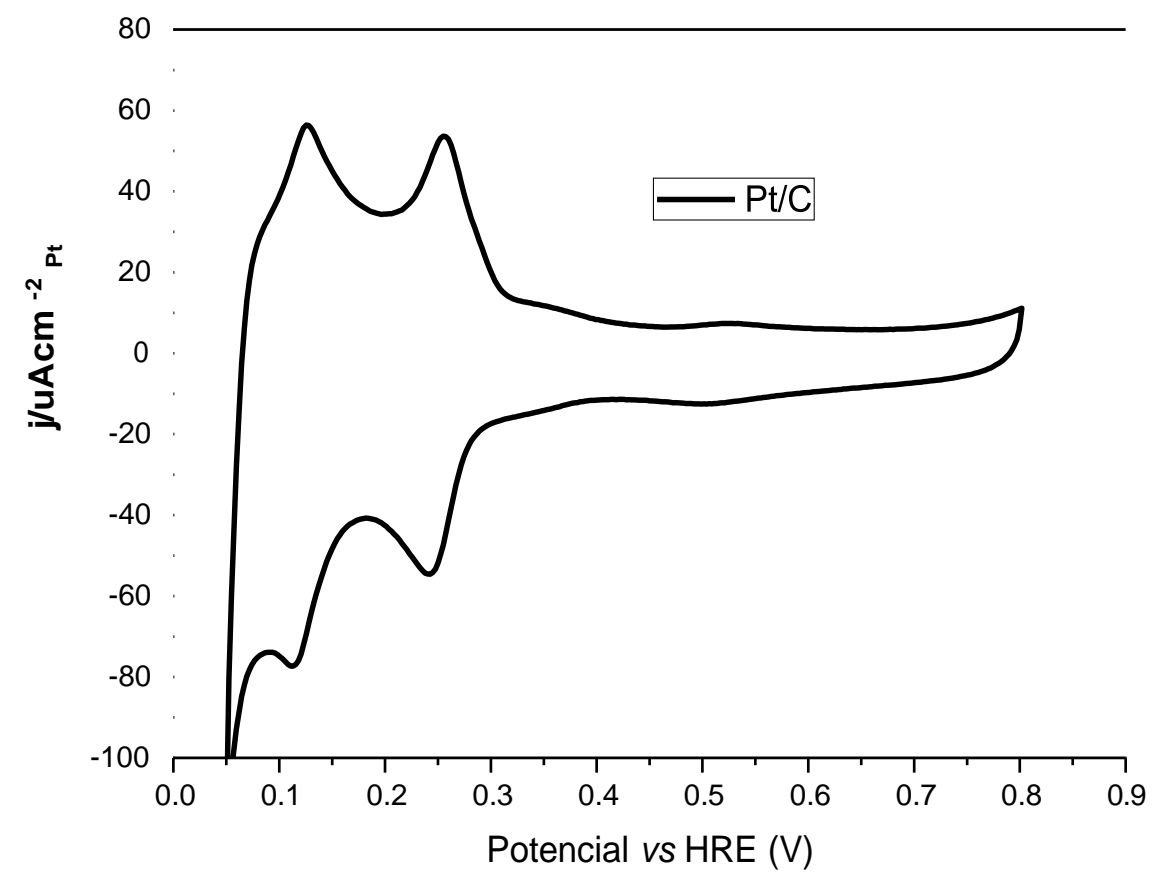

Fonte: Resultado da pesquisa. 
Figura 14 - Voltamograma cíclico do eletrocatalisador Pt/C (100) em solução $0,5 \mathrm{~mol} \mathrm{~L}^{-1}$ de $\mathrm{H}_{2} \mathrm{SO}_{4}$ com velocidade de varredura de $50 \mathrm{mV} \mathrm{s}^{-1}$.
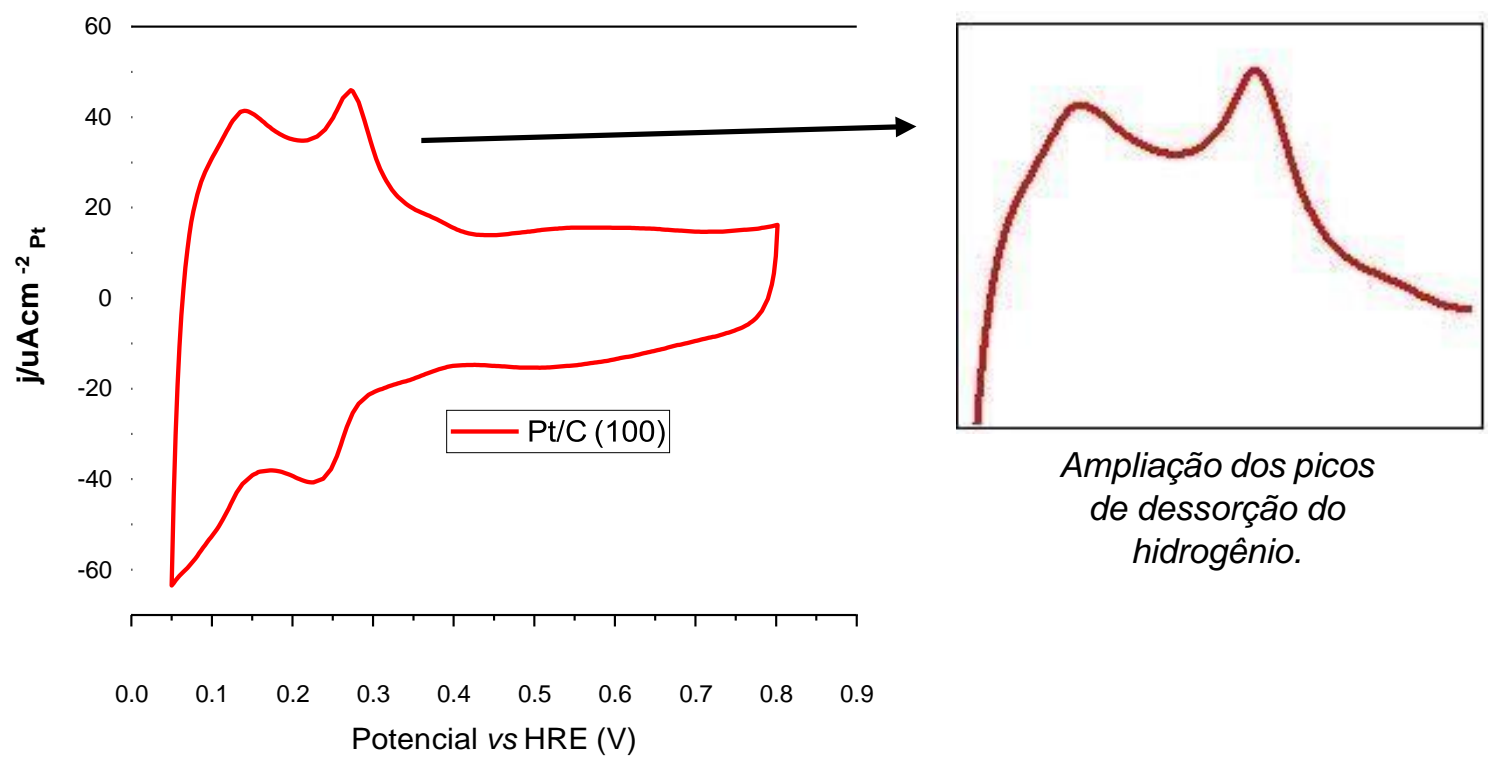

Fonte: Resultado da pesquisa.

Um voltamograma de catalisadores a base Pt suportados em carbono apresenta alguns picos característicos da região de dessorção e adsorção de hidrogênio nas faces cristalográficas da platina, uma região de formação da dupla camada elétrica e outra referente à formação de óxidos ( $\mathrm{PtO}$ ), observados em 0,05 a 0,4 V; 0,4 a 0,7 V e maior que 0,7 V, respectivamente. Sendo que cada morfologia possui concentração de faces cristalinas diferentes na superfície das nanopartículas, as VCs exibem aspectos distintos na primeira região do gráfico (dessorção e adsorção de hidrogênio). Dessa maneira, uma VC pode fornecer uma rápida estimativa sobre a existência dos planos cristalinos na superfície do material estudado, indicando a morfologia das nanopartículas (ANTONIASSI, 2017). Estudos sobre a dessorção de hidrogênio em monocristais de Pt mostram que o pico em torno de 0,125 V corresponde ao processo nos sítios $\mathrm{Pt}(110)$, enquanto que o pico em aproximadamente em $0,27 \mathrm{~V}$ é associado ao processo no sítio $\mathrm{Pt}(100)$, assim como em aproximadamente 0,34 a $0,37 \mathrm{~V}$ na forma de degrau e superfície. Embora esteja na região da dupla camada elétrica, o pico $\cong 0,55 \mathrm{~V}$ está ligado ao processo nos sítios Pt(111) (DOS SANTOS e TREMILIOSI FILHO, 2001).

A partir das Figuras 12, 13 e 14 pode-se verificar no processo de dessorção de hidrogênio a ocorrência dos picos de corrente referente aos sítios $\mathrm{Pt}(110)$ e $\mathrm{Pt}(100)$ para os materiais $\mathrm{Pt} / \mathrm{C}$ comercial (Basf), Pt/C e Pt/C (100). Nota- 
se que para o eletrocatalisador comercial, Pt/C (Basf) (Figura 12), o pico de domínio $\operatorname{Pt}(110)$ é mais intenso que o $\mathrm{Pt}(100)$ numa razão de $\mathrm{I}_{(100)} / \mathrm{I}_{(110)}$ de 0,9 , característica comum na literatura para partículas aproximadamente esféricas (DEVIVARAPRASAD et al., 2014). Assim como no material comercial, o VC do Pt/C também mostra uma maior intensidade para o pico $\operatorname{Pt}(110)$ que para o domínio $\operatorname{Pt}(100)$ (Figura 13), com $\mathrm{I}_{(100)} \mathrm{I}_{(110)} \cong 0,94$, indicando que esse eletrocatalisador também possui nanopartículas policristalinas. Já para o VC do Pt/C (100) (Figura 14), observa-se que a contribuição dos sítios $\mathrm{Pt}(100)$ foi mais intensa que aquela do $\operatorname{Pt}(110)$, sendo a razão entre $I_{(100)} / I_{(110)}$ de 1,10 , aproximadamente. Consequentemente, a morfologia dessas nanopartículas tendeu a ser mais cúbica e a face $\mathrm{Pt}(100)$ se mostrou mais abundante em relação aos outros materiais, resultado este que condiz com os dados de DRX e MET apresentados.

Para os materiais preparados a base de PtRh, os resultados de VC são exibidos nas Figuras 15 e 16.

Figura 15 - Voltamograma cíclico do eletrocatalisador PtRh/C em solução $0,5 \mathrm{~mol} \mathrm{~L}^{-1}$ de $\mathrm{H}_{2} \mathrm{SO}_{4}$ com velocidade de varredura de $50 \mathrm{mV} \mathrm{s}^{-1}$.

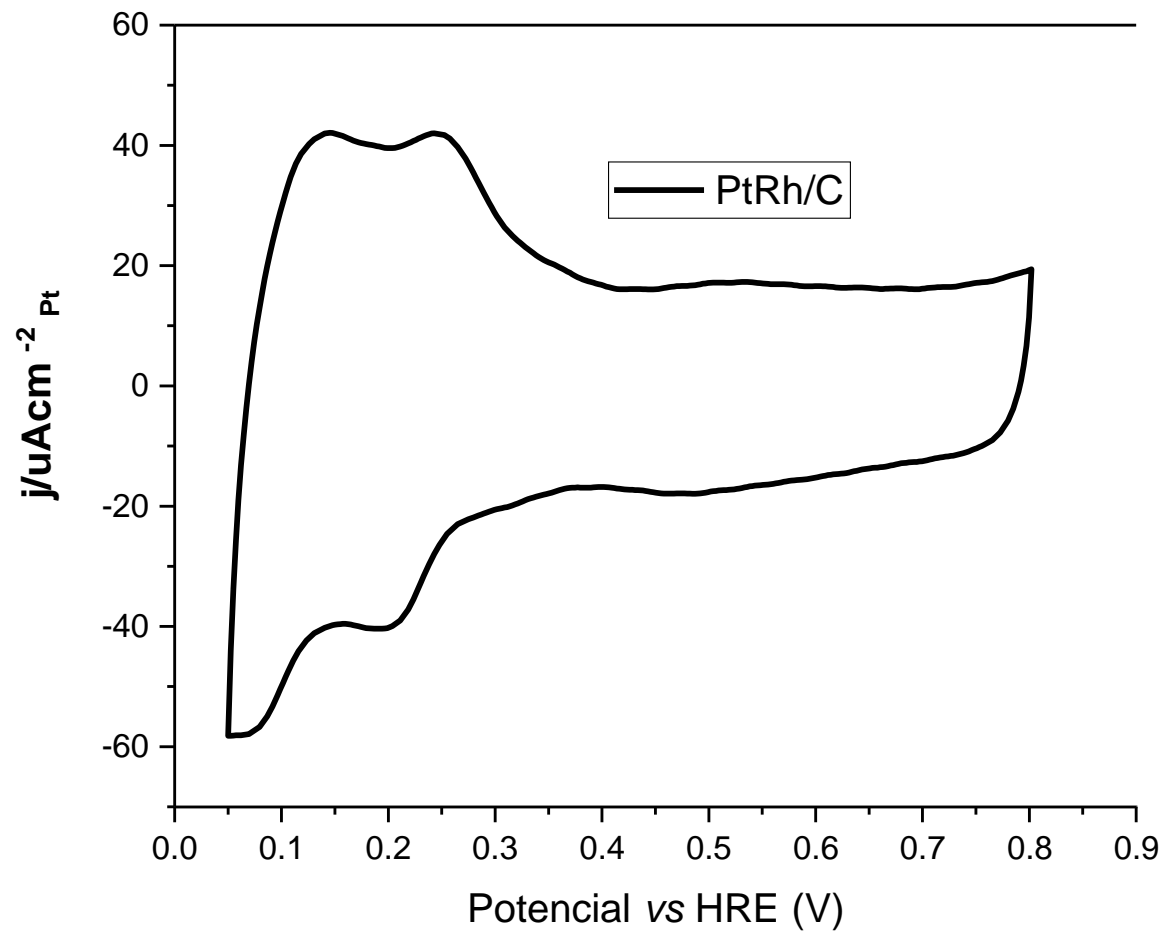

Fonte: Resultado da pesquisa. 
Figura 16 - Voltamograma cíclico do eletrocatalisador PtRh/C (100) em solução $0,5 \mathrm{~mol} \mathrm{~L}^{-1}$ de $\mathrm{H}_{2} \mathrm{SO}_{4}$ com velocidade de varredura de $50 \mathrm{mV} \mathrm{s}^{-1}$.

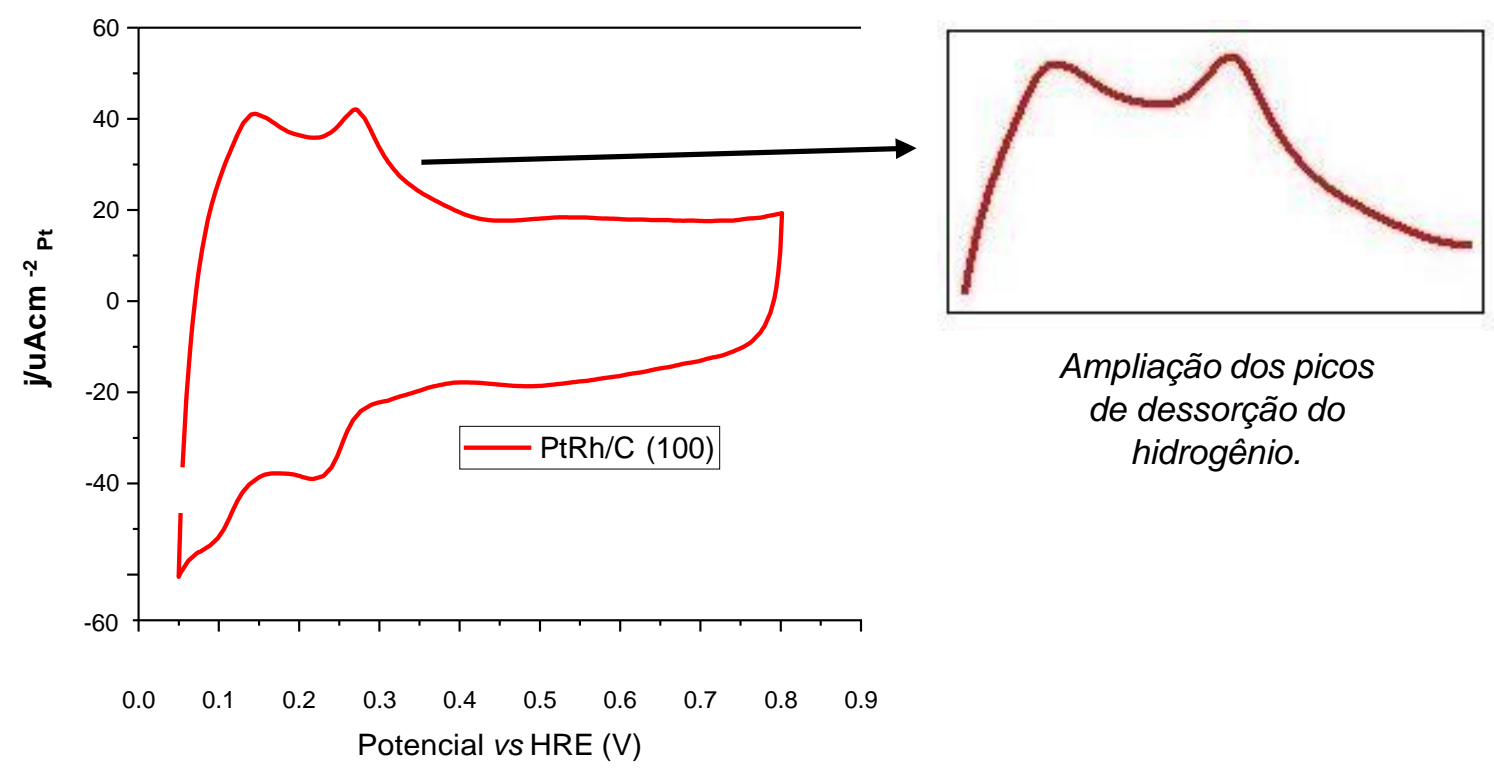

Fonte: Resultado da pesquisa.

A partir das Figuras 15 e 16 pode-se notar que a região de dessorção de hidrogênio, para ambos materiais bi metálicos, não se mostra bem definida como a dos catalisadores a base somente de Pt. Esse efeito pode estar associado a adição de ródio à estrutura da platina, bem como para a realização dos experimentos em meio ácido, onde o ródio tem baixa atividade catalítica (OLIVEIRA NETO et al., 2006; KOWAL et al., 2009; LI et al., 2013). Para o eletrocatalisador PtRh/C o pico dos sítios $\mathrm{Pt}(110)$ teve intensidade bem próxima ao $\mathrm{Pt}(100)$, sendo que a razão entre $I_{(100)} / I_{(110)}$ foi aproximadamente 1 . Resultado similar ocorreu com o PtRh/C (100), porém neste último a maior intensidade se deu no domínio $\operatorname{Pt}(100)$, sendo $\mathrm{I}_{(100)} / \mathrm{I}_{(110)} \cong 1,03$. Além disso, foi possível verificar uma discreta fase em $0,37 \mathrm{~V}$ (visível também para o $\mathrm{Pt} / \mathrm{C}(100)$ ), correspondente à superfícies $\mathrm{Pt}(100)$, visualmente ausente para os materiais sintetizados sem crescimento preferencial. Esse resultado aliado aqueles já expostos vão de acordo com a orientação preferencial pretendida para o material em questão, uma vez que os eletrocatalisadores sintetizados neste trabalho apresentam morfologias preferencialmente direcionadas no plano cristalográfico (100) e não monocristais de domínio único. 


\subsection{Estudos da eletro-oxidação do etanol}

\subsubsection{Voltametria cíclica e Cronoamperometria}

Para avaliar o desempenho dos materiais na eletro-oxidação do etanol o experimento de VC foi realizado em solução ácida de etanol. A Figura 17 apresenta o voltamograma linear dos eletrocatalisadores normalizados por área ativa.

Figura 17 - Voltamograma linear potenciostático dos eletrocatalisadores $\mathrm{Pt} / \mathrm{C}, \mathrm{Pt} / \mathrm{C}$ Basf, $\mathrm{Pt} / \mathrm{C}$ (100), PtRh/C e PtRh/C (100), em solução $0,5 \mathrm{~mol} \mathrm{~L}^{-1}$ de $\mathrm{H}_{2} \mathrm{SO}_{4}$ e $1,0 \mathrm{~mol} \mathrm{~L}^{-1}$ de etanol com velocidade de varredura de $50 \mathrm{mV} \mathrm{s}^{-1}$.

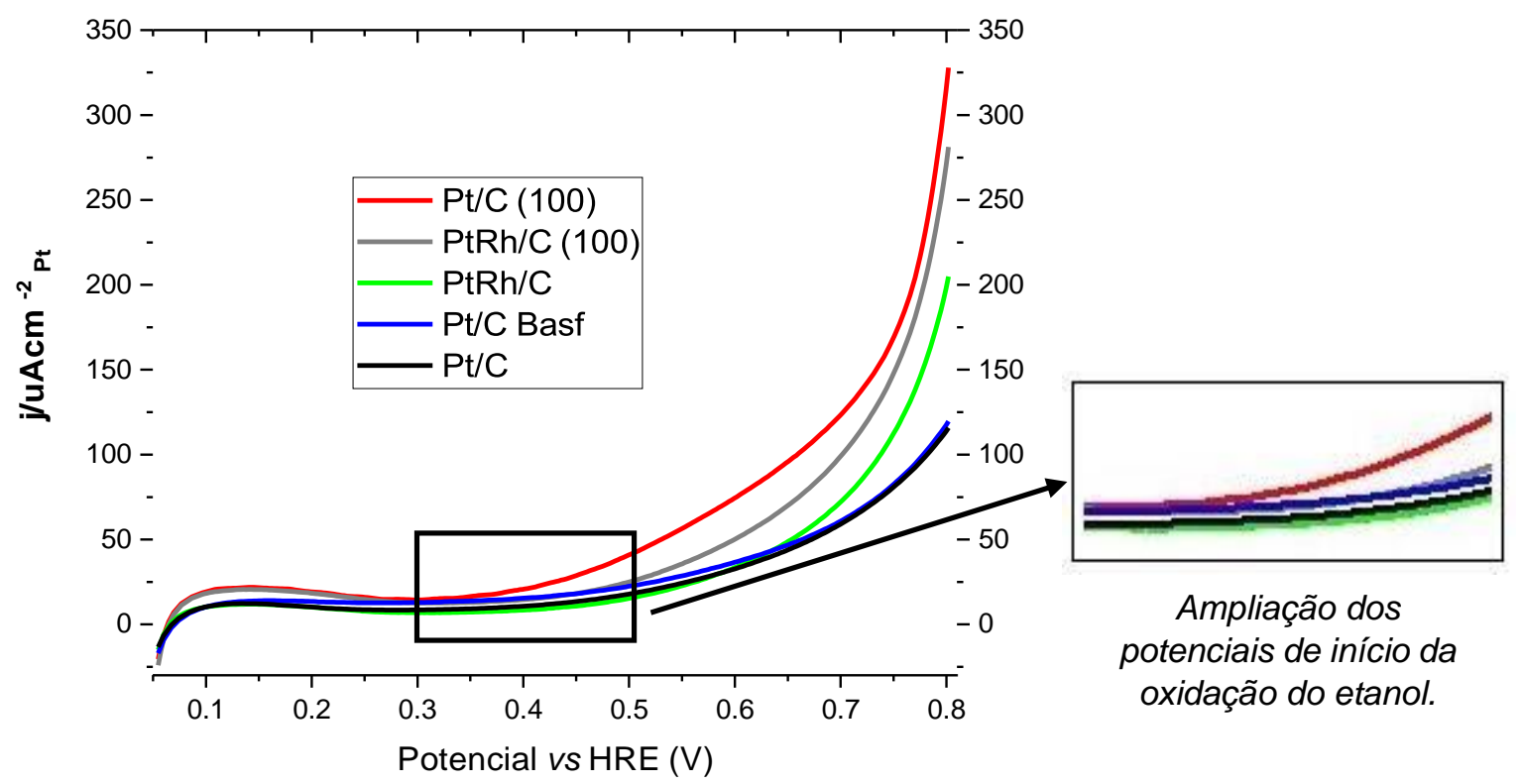

Fonte: Resultado da pesquisa.

Como visto, o eletrocatalisador Pt/C (100) foi o que apresentou maior densidade de corrente, sendo que o material PtRh/C (100) também demonstrou ser mais ativo na eletro-oxidação do etanol. Para melhor visualização das informações com relação a Figura 17, construiu-se a Tabela 3 onde estão apresentados os valores de densidade de corrente e o potencial de início da oxidação do etanol para cada eletrocatalisador. 
Tabela 3 - Potenciais médios de início da oxidação do etanol e densidade máxima de corrente dos eletrocatalisadores Pt/C, Pt/C Basf, Pt/C (100), PtRh/C e PtRh/C (100).

\begin{tabular}{c|c|c}
\hline Eletrocatalisador & $\begin{array}{c}\text { Início da oxidação do } \\
\text { etanol }\end{array}$ & $\begin{array}{c}\text { Densidade máxima de } \\
\text { corrente } /\left(\mathbf{u A ~ c m} \mathbf{~ c m}^{-2} \mathbf{~ P t}\right)\end{array}$ \\
\hline $\mathrm{Pt} / \mathrm{C}(100)$ & $0,31 \mathrm{~V}$ & 327 \\
\hline $\mathrm{PtRh} / \mathrm{C}(100)$ & $0,34 \mathrm{~V}$ & 281 \\
\hline $\mathrm{PtRh} / \mathrm{C}$ & $0,33 \mathrm{~V}$ & 205 \\
\hline $\mathrm{Pt} / \mathrm{C} \mathrm{Basf}$ & $0,31 \mathrm{~V}$ & 120 \\
\hline $\mathrm{Pt} / \mathrm{C}$ & $0,30 \mathrm{~V}$ & 116 \\
\hline
\end{tabular}

Fonte: Resultado da pesquisa.

Conforme a Tabela 3, verifica-se que o potencial de início de oxidação foi de aproximadamente $0,3 \vee$ para todos os eletrocatalisadores estudados. Porém a densidade de corrente gerada foi muito maior para os materiais com orientação preferencial quando comparados aqueles sem orientação. O material Pt/C (100) teve uma corrente de aproximadamente 3 vezes maior que o catalisador comercial (Pt/C Basf) e o Pt/C policristalino. De maneira semelhante, o PtRh/C (100) mostrou uma densidade de corrente aproximadamente 2,3 vezes maior que os eletrocatalisadores Pt/C Basf e Pt/C. Quando comparado ao material PtRh/C sem direcionamento o eletrocatalisador $\mathrm{PtRh} / \mathrm{C}(100)$ exibiu um valor $37 \%$ maior de corrente, ficando bem próximo do material Pt/C (100) que mostrou a maior atividade na eletro-oxidação do etanol. $\mathrm{O}$ material $\mathrm{PtRh} / \mathrm{C}$ sem direcionamento também apresentou uma densidade de corrente relativamente alta, sendo $71 \%$ maior que a do eletrocatalisador comercial. Este fato provavelmente se deve a capacidade do ródio em atuar na clivagem da ligação $C-C$ existente na molécula do etanol KAMARUDIN e AKHAIRI, (2016); XIE et al. (2019); SALAZAR-BANDA et al. (2019), o que consequentemente aumenta a atividade do eletrocatalisador para a reação proposta. Em contrapartida, os valores baixos para os materiais $\mathrm{Pt} / \mathrm{C}$ sem orientação preferencial e para o Pt/C Basf sugerem mais intermediários adsorvidos em suas superfícies. Além disso, conforme verificado anteriormente, para as nanopartículas cúbicas a oxidação do monóxido de carbono ocorre em menores potenciais em comparação com aqueles observados pelas nanopartículas de forma 
esférica, fato que potencialmente contribui com a maior atividade catalítica dos materiais com orientação preferencial para a oxidação do etanol.

Afim de avaliar a estabilidade eletrocatalítica dos materiais a técnica de cronoamperometria foi realizada em potencial constante de $0,5 \mathrm{~V}$ mantido por 1 hora. Os resultados estão expostos na Figura 18.

Figura 18 - Cronoamperometria dos eletrocatalisadores Pt/C, Pt/C Basf, Pt/C (100), PtRh/C e $\mathrm{PtRh} / \mathrm{C}$ (100) obtidas com potencial fixo de $0,5 \mathrm{~V}$ em solução $0,5 \mathrm{~mol} \mathrm{~L}^{-1} \mathrm{de}_{2} \mathrm{SO}_{4}$ e $1,0 \mathrm{~mol} \mathrm{~L}^{-1}$ de etanol.

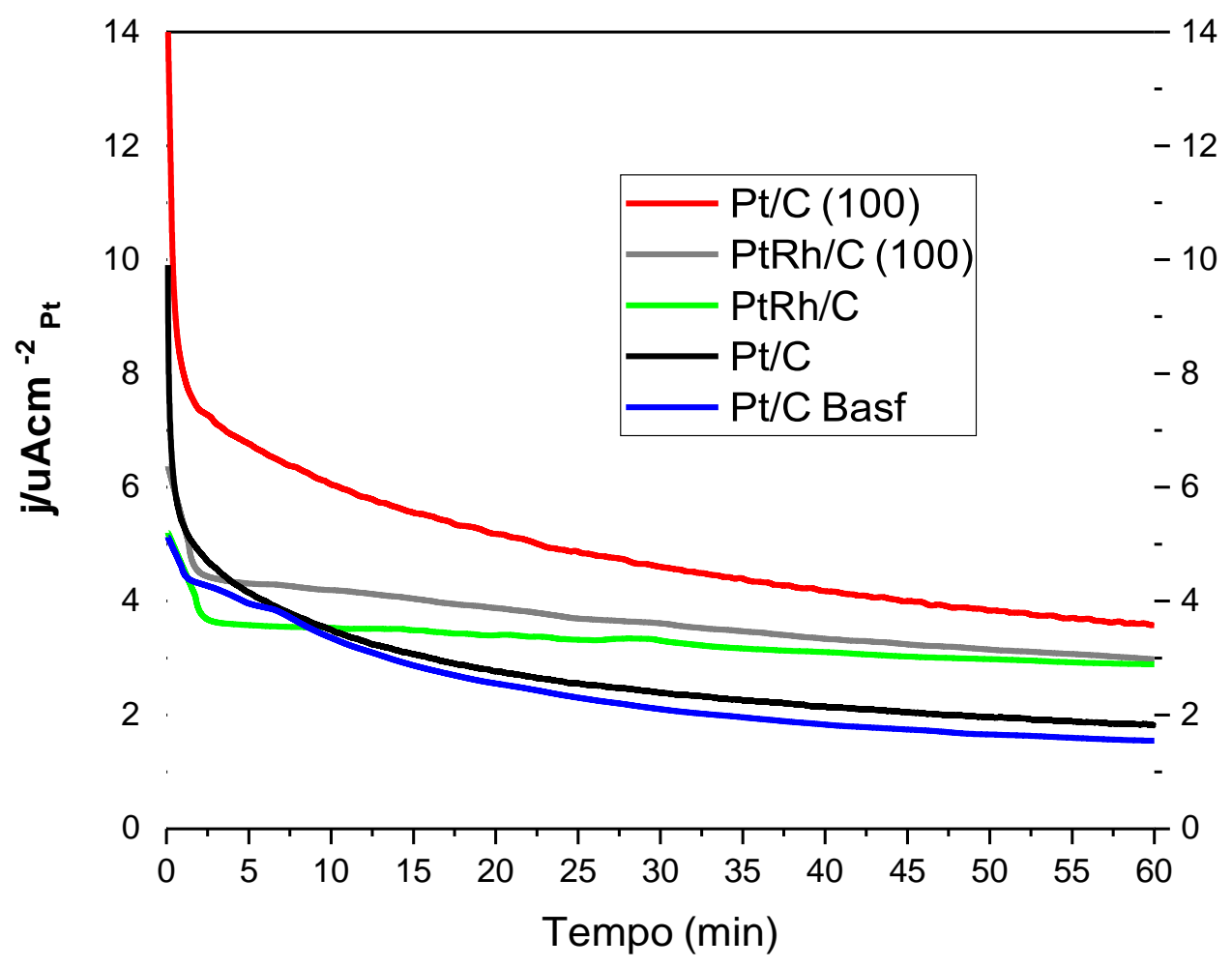

Fonte: Resultado da pesquisa.

Nos primeiros minutos de experimento, região de transiente potenciostático (de 0 a 7 minutos aproximadamente) ocorreu uma queda de densidade de corrente mais pronunciada para os eletrocatalisadores $\mathrm{Pt} / \mathrm{C}$ e $\mathrm{Pt} / \mathrm{C}$ Basf, enquanto que os demais apresentaram uma queda menor nessa região. Notase também que os materiais binários apresentaram uma maior estabilidade na densidade de corrente durante todo o experimento e que o eletrocatalisador Pt/C (100) mostrou maior densidade de corrente do início ao fim do experimento de cronoamperometria, concordando com os demais resultados. Os valores finais de 
corrente para os eletrocatalisadores testados pela técnica de cronoamperometria estão dispostos na Tabela 4.

Tabela 4 - Valores finais de densidade de corrente para os eletrocatalisadores Pt/C, Pt/C Basf, $\mathrm{Pt} / \mathrm{C}$ (100), PtRh/C e PtRh/C (100).

\begin{tabular}{|c|c|}
\hline Eletrocatalisador & $\begin{array}{l}\text { Valores finais de densidade de corrente/(uA } \\
\left.\qquad \mathrm{cm}^{-2} \mathrm{Pt}\right)\end{array}$ \\
\hline $\mathrm{Pt} / \mathrm{C}(100)$ & 3,6 \\
\hline $\mathrm{Pt} / \mathrm{C}$ & 1,8 \\
\hline $\mathrm{Pt} / \mathrm{C}$ Basf & 1,5 \\
\hline $\mathrm{PtRh} / \mathrm{C}$ & 2,9 \\
\hline $\mathrm{PtRh} / \mathrm{C}(100)$ & 3,0 \\
\hline
\end{tabular}

Fonte: Resultado da pesquisa.

O material Pt/C (100) foi quem apresentou maior densidade final de corrente, seguido pelo PtRh/C (100). Contudo, este último apresentou valor final de corrente bem próximo ao $\mathrm{PtRh} / \mathrm{C}$. Já para os materiais $\mathrm{Pt} / \mathrm{C}$ e $\mathrm{Pt} / \mathrm{C}$ Basf o resultado é condizente com os demais, uma vez que todos os resultados mostram a baixa atividade eletrocatalítica destes materiais. 
5.6.2 Experimentos em célula a combustível de etanol direto

Os resultados dos experimentos em célula unitária DEFC são apresentados na Figura 19.

Figura 19 - Curvas de polarização e densidade de potência para os eletrocatalisadores estudados.

a) curva de polarização; b) curva de densidade de potência, ambos normalizados por área geométrica do eletrodo. c) curva de polarização; d) curva de densidade de potência, ambos normalizados por área eletroquimicamente ativa.
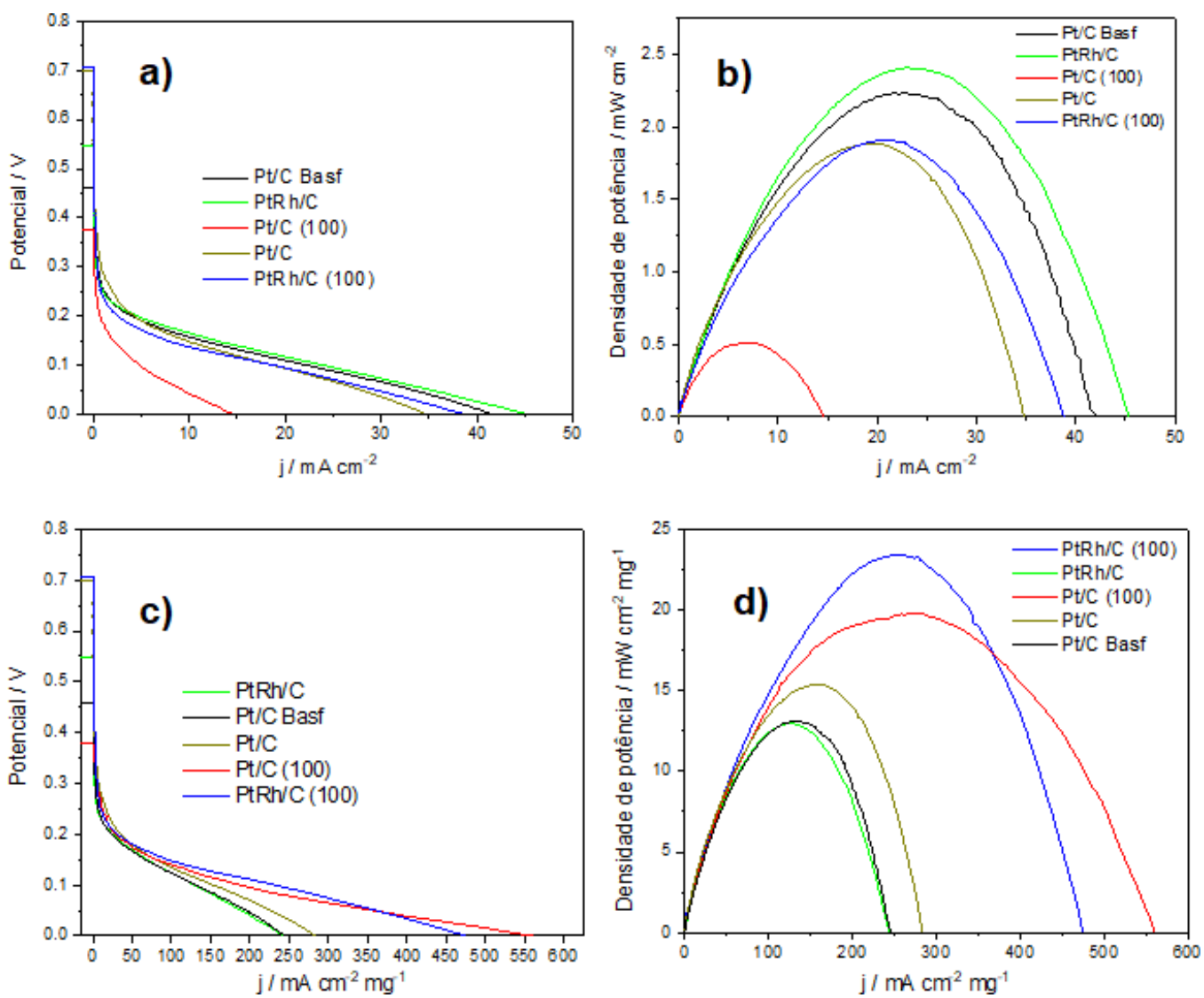

Fonte: Resultado da pesquisa.

As curvas de polarização (Figuras 19a e 19c) apresentam um potencial de circuito aberto que varia de aproximadamente $0.38 \mathrm{~V}$, para o eletrocatalisador $\mathrm{Pt} / \mathrm{C}$ (100), até aproximadamente $0.71 \mathrm{~V}$, para o eletrocatalisador PtRh/C (100) como mostrado na Tabela 5. 
Tabela 5 - Potencial de circuito aberto obtido em uma DEFC para os eletrocatalisadores estudados.

\begin{tabular}{|c|c|}
\hline Eletrocatalisador & Potencial de circuito aberto (em V) \\
\hline $\mathrm{PtRh} / \mathrm{C}(100)$ & 0,71 \\
\hline $\mathrm{Pt} / \mathrm{C}$ & 0,70 \\
\hline $\mathrm{PtRh} / \mathrm{C}$ & 0,55 \\
\hline Pt/C Basf & 0,46 \\
\hline $\mathrm{Pt} / \mathrm{C}(100)$ & 0,38 \\
\hline
\end{tabular}

Fonte: Resultado da pesquisa.

Como se observa, os potenciais de circuito aberto seguiram a seguinte ordem: $\mathrm{PtRh} / \mathrm{C}(100)>\mathrm{Pt} / \mathrm{C}>\mathrm{PtRh} / \mathrm{C}>\mathrm{Pt} / \mathrm{C}$ Basf $>\mathrm{Pt} / \mathrm{C}(100)$.

Avaliando os resultados de densidade de potência considerando a área do eletrodo (Figura 19 b)) foi observada que o catalisador $\mathrm{PtRh} / \mathrm{C}$ apresentou maior desempenho seguido pelo $\mathrm{Pt} / \mathrm{C}$ Basf $>\mathrm{PtRh} / \mathrm{C}(100)>\mathrm{Pt} / \mathrm{C}>\mathrm{Pt} / \mathrm{C}$ (100), como mostrado na Tabela 6 , quando a densidade máxima de potência é normalizada pela área do eletrodo.

Tabela 6 - Densidade máxima de potência obtido em uma DEFC para os eletrocatalisadores estudados.

\begin{tabular}{|c|c|c|}
\hline \multirow[t]{2}{*}{ Eletrocatalisador } & \multicolumn{2}{|c|}{ Densidade máxima de potência } \\
\hline & $\begin{array}{l}\text { Área do eletrodo } \\
\left(\mathrm{mW} / \mathrm{cm}^{-2}\right)\end{array}$ & $\begin{array}{c}\text { Área ativa } \\
\left(\mathrm{mW} / \mathrm{cm}^{-2} \mathrm{mg}^{-1}\right)\end{array}$ \\
\hline $\mathrm{PtRh} / \mathrm{C}(100)$ & 1,9 & 23,3 \\
\hline $\mathrm{Pt} / \mathrm{C}(100)$ & 0,5 & 19,8 \\
\hline $\mathrm{PtRh} / \mathrm{C}$ & 2,4 & 12,9 \\
\hline $\mathrm{Pt} / \mathrm{C}$ & 1,8 & 15,3 \\
\hline Pt/C Basf & 2,2 & 13,1 \\
\hline
\end{tabular}

Fonte: Resultado da pesquisa.

Contudo quando as curvas de densidade máxima de potência (Figura 19d) são normalizados por área eletroquimicamente ativa de metal (Tabela 6), os eletrocatalisadores com orientação preferencial na direção (100) apresentaram um 
aumento significativo no desempenho, sendo que o eletrocatalisador $\mathrm{PtRh} / \mathrm{C}$ (100) mostra uma densidade de potência quase o dobro do valor apresentado pelo eletrocatalisador comercial. Isso pode ser explicado pela diferença no tamanho das nanopartículas para os diferentes eletrocatalisadores, uma vez que os eletrocatalisadores sem orientação preferencial apresentam um tamanho médio de nanopartículas em torno de $3 \mathrm{~nm}$, sendo que para materiais com orientação preferencial este valor aumenta para cerca de $8 \mathrm{~nm}$. Assim a ordem de densidade de corrente em mW cm${ }^{-2} \mathrm{mg}^{-1}$ foi: PtRh/C (100) > Pt/C (100) > Pt/C > Pt/C Basf $\mathrm{PtRh} / \mathrm{C}$.

5.6.3 Estudos on-line da eletro-oxidação do etanol por espectrometria de massas diferencial (DMS) e análise dos efluentes da DEFC por ATR-FTIR

Com a finalidade de caracterizar os produtos formados na eletrooxidação do etanol os experimentos de DMS e ATR - FTIR foram realizados. Primeiro apresentamos o resultado de DMS obtido para a EOR, sendo exibido na Figura 20.

Para o resultado de DMS apresentado com relação $\mathrm{m} / \mathrm{z}=44$ (produtos com massa igual a 44) são referentes à produção de $\mathrm{CO}_{2} \mathrm{e}$ acetaldeído, observase que para o eletrocatalisador $\mathrm{Pt} / \mathrm{C}$ Basf a formação de produtos tem início em aproximadamente 0,45 V. Pelo espectro de ATR - FTIR apresentado (Figura 21) observa-se as bandas referente ao ácido acético em $1282 \mathrm{~cm}^{-1} \mathrm{e}$ acetaldeido em $933 \mathrm{~cm}^{-1}$ (NIST Chemistry WebBook) com potencial em 0,3 V, porém não são mais observáveis em $0 \mathrm{~V}$. Isso indica uma possível coexistência entre ácido acético, $\mathrm{CO}_{2}$ e acetaldeído em maiores potenciais, e com a diminuição do potencial aplicado (próximo a zero) o produto formado tende a ser apenas o dióxido de carbono. $\mathrm{O}$ resultado para $\mathrm{m} / \mathrm{z}=60$ (formação do ácido acético) confirma a existência de ácido acético em aproximadamente $0,45 \mathrm{~V}$ até $0,05 \mathrm{~V}$, sendo que a partir disso decrescendo o potencial aplicado a formação deste produto tende a zero. 
Figura 20 - Resultados dos espectrômetros de massas eletroquímica diferencial para os eletrocatalisadores estudados, analisados pelo efluente de uma DEFC.
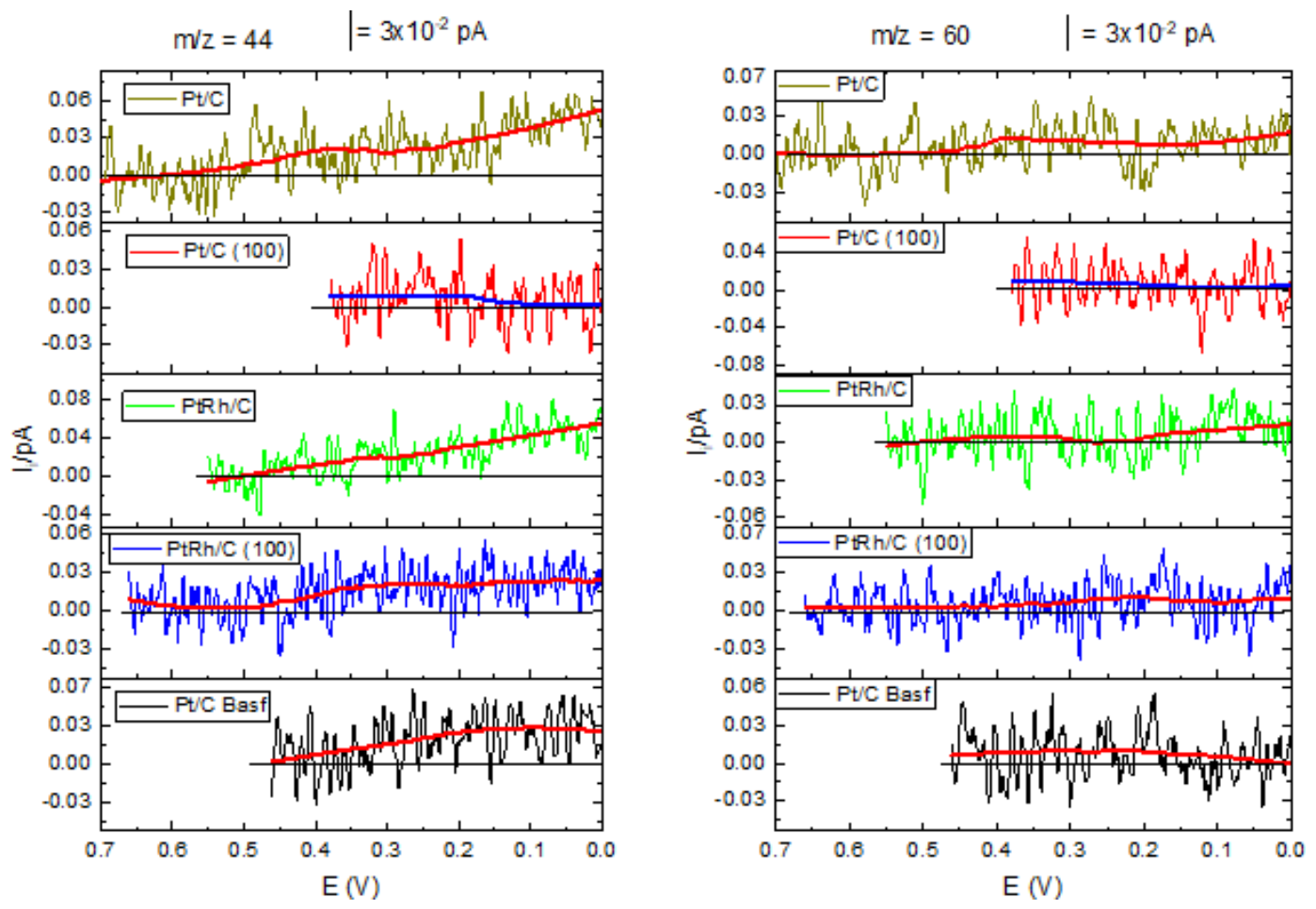

Fonte: Resultado da pesquisa. 
Figura 21 - Resultados dos experimentos de espectroscopia na região do infravermelho com transformada de Fourier e refletância total atenuada, analisados pelo efluente de uma DEFC, para os eletrocatalisadroes Pt/C Basf, em a) e Pt/C em b).
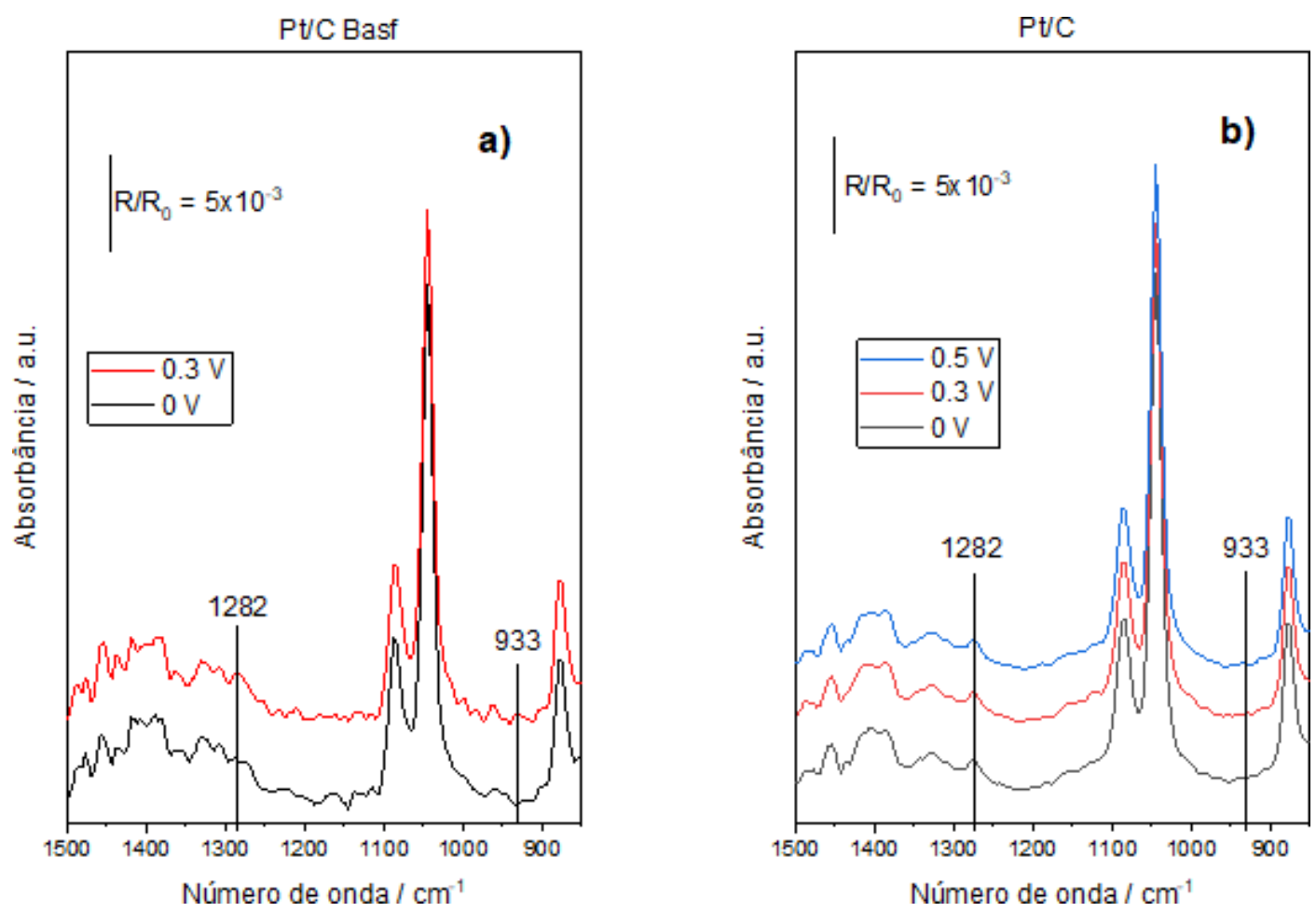

Fonte: Resultado da pesquisa.

Em relação ao eletrocatalisador $\mathrm{Pt} / \mathrm{C}$ observamos que os produtos são detectáveis em toda a faixa de potencial apresentado, de $0,7 \mathrm{~V}$ a $0 \mathrm{~V}$. Para os produtos com $\mathrm{m} / \mathrm{z}=44$ observa-se que de $0,7 \mathrm{~V}$ até aproximadamente $0,55 \mathrm{~V}$ os produtos formados são praticamente zero, a partir de $0.55 \mathrm{~V}$ há um aumento na produção desses produtos, sendo quase que estável até próximo a $0,2 \mathrm{~V}$, onde novamente ocorre um incremento na produção e segue aumentando até o potencial $0 \mathrm{~V}$. Já para os produtos com relação $\mathrm{m} / \mathrm{z}=60$ é observado que até próximo de 0,5 $\checkmark$ a detecção dos produtos é nula (zero), sendo que a partir desse potencial é possível observar a formação do ácido acético de maneira praticamente constante. Pelos resultados de FTIR podemos notar a presença das bandas em $1282 \mathrm{~cm}^{-1}$ para todos os três potenciais analisados, contudo não se observa a formação da banda em $933 \mathrm{~cm}^{-1}$ referente ao acetaldeído, indicando assim que este catalisador teve maior seletividade à formação de $\mathrm{CO}_{2}$ quando comparado com o $\mathrm{Pt} / \mathrm{C}$ Basf.

O eletrocatalisador Pt/C (100) apresenta o início de formação de produtos em aproximadamente $0,37 \mathrm{~V}$, e exibe um decréscimo na detecção dos 
produtos formados, tanto para $\mathrm{m} / \mathrm{z}=44$ quanto para $\mathrm{m} / \mathrm{z}=60$, sendo que em ambos os resultados é possível observar a formação dos produtos em até aproximadamente $0,15 \mathrm{~V}$. Contudo, é notável que para os produtos $\mathrm{com} \mathrm{m} / \mathrm{z}=44$ há uma maior intensidade na formação dos produtos quando comparado à detecção do ácido acético $(\mathrm{m} / \mathrm{z}=60)$. A partir do resultado de FTIR (Figura 22a), podemos observar claramente a formação de apenas uma banda em $1282 \mathrm{~cm}^{-1}$, se referindo a formação do ácido acético, indicando assim que os produtos detectados no DMS com massa igual a 44 é referente apenas ao dióxido de carbono, mostrando que este catalisador também apresenta uma maior tendência à formação deste produto.

Figura 22 - Resultados dos experimentos de espectroscopia na região do infravermelho com transformada de Fourier e refletância total atenuada, analisados pelo efluente de uma DEFC, para os eletrocatalisadroes $\mathrm{Pt} / \mathrm{C}$ (100), em a) e $\mathrm{PtRh} / \mathrm{C} \mathrm{em} \mathrm{b).}$
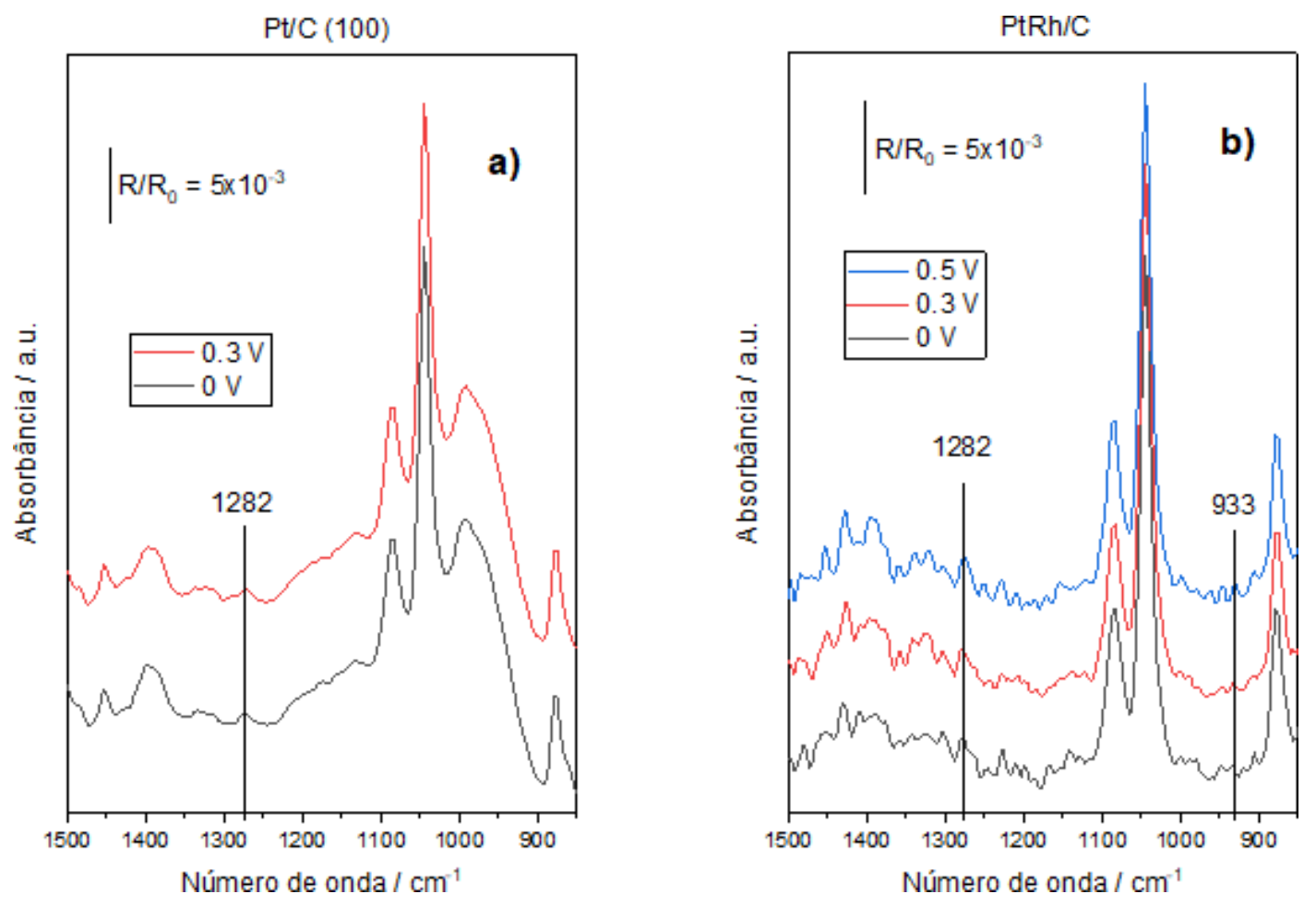

Fonte: Resultado da pesquisa.

Para o eletrocatalisador PtRh/C é observado um comportamento quase que totalmente crescente para os produtos com relação $\mathrm{m} / \mathrm{z}=44$ (Figura 20), apenas no intervalo entre $0,35 \mathrm{~V}$ e $0,25 \mathrm{~V}$ nota-se uma estabilidade dos produtos gerados. É importante notar também que o início de formação de produtos para 
este catalisador é detectável a partir de $0,55 \mathrm{~V}$, sendo os produtos com massa igual a 44 formados com maior intensidade em relação ao ácido acético $(\mathrm{m} / \mathrm{z}=60)$. Além disso, para a relação $\mathrm{m} / \mathrm{z}=60$ é possível observar que entre $0,55 \mathrm{~V}$ até aproximadamente $0,5 \mathrm{~V}$ sua formação é praticamente nula (igual a zero), e decrescendo o potencial aplicado há um leve incremento até 0,35 V. Após há uma queda até aproximadamente $0,3 \mathrm{~V}$ onde novamente sua detecção passa a ser nula até um potencial próximo de $0,2 \mathrm{~V}$, quando há novamente um incremento na produção de ácido acético até o final do experimento de DEMS. Correlacionando esses resultados com os do FTIR (Figura 22b) notamos também a presença de ácido acético em $1282 \mathrm{~cm}^{-1}$ para os três potenciais analisados. Porém para o acetaldeído em $933 \mathrm{~cm}^{-1}$ não podemos afirmar uma possível detecção nos potenciais analisados, uma vez que o ruído apresentado nesta faixa de número de onda foi muito grande. Assim, acreditamos que o produto detectado no experimento de DEMS com relação $\mathrm{m} / \mathrm{z}=44$ deve-se à formação de $\mathrm{CO}_{2}$.

Figura 23 - Resultado do experimento de espectroscopia na região do infravermelho com transformada de Fourier e refletância total atenuada, analisados pelo efluente de uma DEFC, para o eletrocatalisador $\mathrm{PtRh} / \mathrm{C}(100)$.

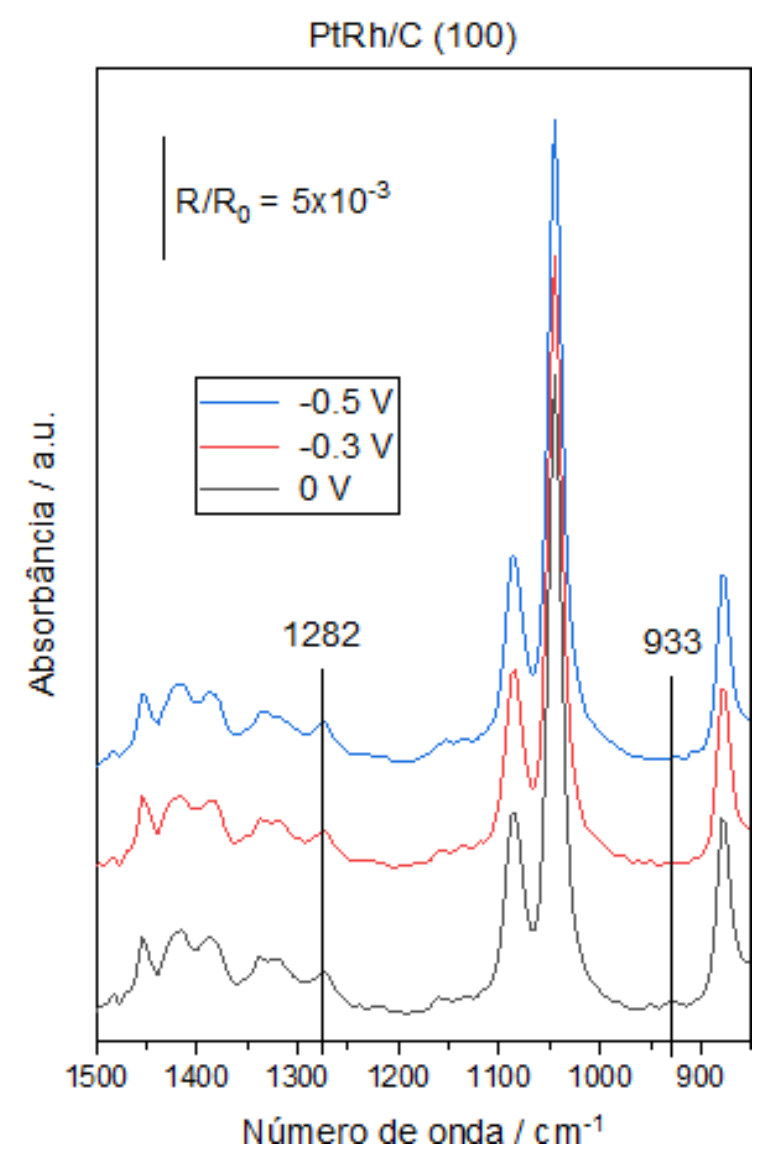

Fonte: Resultado da pesquisa. 
O resultado de DMS para o eletrocatalisador PtRh/C (100) (Figura 20) exibe uma detecção dos produtos sendo formados a partir de 0,65 V, com os produtos de massa $=44$ apresentando maior intensidade de formação quando comparados com a relação $\mathrm{m} / \mathrm{z}=60$. Observa-se também que para o resultado $\mathrm{m} / \mathrm{z}$ = 44 ocorre uma queda na formação dos produtos até aproximadamente 0,5 V, quando ocorre aumento na formação dos produtos até um potencial próximo de 0,35 $\mathrm{V}$ e se mantém praticamente constante até o fim do experimento. Relacionando este fato com o resultado de FTIR (Figura 23) apresentado para este eletrocatalisador, podemos inferir que até $0,5 \mathrm{~V}$ houve um consumo de acetaldeído formado e produção de $\mathrm{CO}_{2}$ até próximo do potencial $0 \mathrm{~V}$, onde podemos observar uma leve contribuição da banda em $933 \mathrm{~cm}^{-1}$ referente ao acetaldeído, sugerindo que em potenciais próximos a $0 \mathrm{~V}$ há a coexistência dos produtos dióxido de carbono e acetaldeído e que em potenciais maiores $(0,3 \mathrm{~V}$ e 0,5 V) o produto detectado pelo DMS com relação $\mathrm{m} / \mathrm{z}=44$ é referente apenas ao $\mathrm{CO}_{2}$. Já a formação do ácido acético é observável nos três potenciais analisados, estando de acordo com o resultado apresentado pelo experimento de DMS, onde podemos notar a formação do produto com relação $\mathrm{m} / \mathrm{z}=60$ a partir de $0,5 \mathrm{~V}$, aumentando até aproximadamente $0,3 \mathrm{~V}$ e mantendo-se praticamente constante até o final do experimento. 


\subsection{Estudos da eletro-oxidação do glicerol}

\subsubsection{Experimentos em célula a combustível de glicerol direto}

Figura 24 - Curvas de polarização e densidade de potência para os eletrocatalisadores estudados. a) curva de polarização; b) curva de densidade de potência, ambos normalizados por área geométrica do eletrodo. c) curva de polarização; d) curva de densidade de potência, ambos normalizados por área eletroquimicamente ativa.
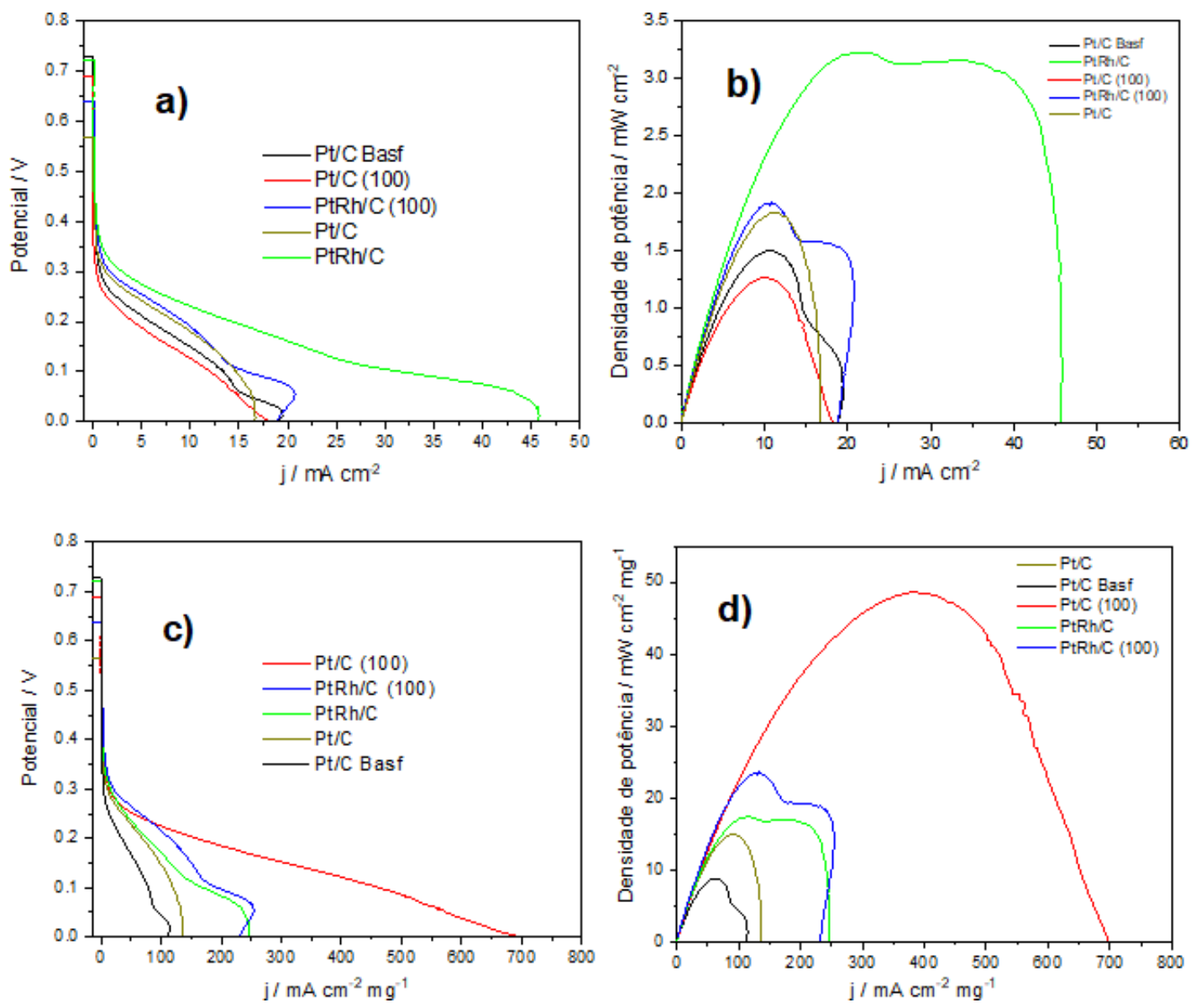

Fonte: Resultado da pesquisa.

As curvas de polarização (Figuras 24a e 24c) apresentam um potencial de circuito aberto relativamente maior que os testes realizados para a oxidação do etanol. Outra diferença observada foi em relação a ordem dos potenciais gerados pelos eletrocatalisadores para a oxidação do glicerol, sendo que o os maiores potenciais apresentados foram de $0,73 \mathrm{~V}$ e $0,72 \mathrm{~V}, \mathrm{Pt} / \mathrm{C}$ Basf e $\mathrm{PtRh} / \mathrm{C}$ respectivamente, seguidos por: $\mathrm{Pt} / \mathrm{C}(100)>\mathrm{PtRh} / \mathrm{C}(100)>\mathrm{Pt} / \mathrm{C}$. Os resultados são mostrados na Tabela 7. 
Tabela 7 - Potencial de circuito aberto obtido em uma DEFC para os eletrocatalisadores estudados.

\begin{tabular}{c|c}
\hline Eletrocatalisador & Potencial de circuito aberto (em V) \\
\hline $\mathrm{Pt} / \mathrm{C}$ Basf & 0,73 \\
$\mathrm{PtRh} / \mathrm{C}$ & 0,72 \\
$\mathrm{Pt} / \mathrm{C}(100)$ & 0,69 \\
\hline $\mathrm{PtRh} / \mathrm{C}(100)$ & 0,64 \\
$\mathrm{Pt} / \mathrm{C}$ & 0,57 \\
\hline
\end{tabular}

Fonte: Resultado da pesquisa.

Como é possível observar o menor potencial de circuito aberto apresentado pelos eletrocatalisadores para a GOR foi de $0,57 \mathrm{~V}$, consideravelmente maior que os $0,38 \mathrm{~V}$ apresentado para a EOR.

Ao avaliarmos as curvas de densidade de potência (Figura 24b e 24d), observamos que os valores apresentados para a GOR também se mostram superiores aqueles mostrados para a EOR. Todos os valores de densidade máxima de potência observados para os eletrocatalisadores estudados são apresentados na tabela a seguir.

Tabela 8 - Densidade máxima de potência obtido em uma DGFC para os eletrocatalisadores estudados.

\begin{tabular}{c|c|c}
\hline Eletrocatalisador & \multicolumn{2}{|c}{ Densidade máxima de potência } \\
& $\begin{array}{c}\text { Área do eletrodo } \\
\left(\mathbf{m W} / \mathbf{~ c m}^{-2}\right)\end{array}$ & $\begin{array}{c}\text { Área ativa } \\
\left(\mathbf{m W} / \mathbf{c m}^{-2} \mathbf{~ m g}^{-1}\right)\end{array}$ \\
\hline $\mathrm{PtRh} / \mathrm{C}(100)$ & 1,93 & 23,7 \\
\hline $\mathrm{Pt} / \mathrm{C}(100)$ & 1,27 & 46,66 \\
$\mathrm{PtRh} / \mathrm{C}$ & 3,23 & 17,36 \\
$\mathrm{Pt} / \mathrm{C}$ & 1,84 & 15 \\
\hline $\mathrm{Pt} / \mathrm{C} \mathrm{Basf}$ & 1,5 & 8,83 \\
\hline
\end{tabular}

Fonte: Resultado da pesquisa. 
Como podemos notar o material PtRh/C novamente apresentou a maior densidade de potência (Figura 24b) quando considerado a área do eletrodo, sendo que este eletrocatalisador expos uma densidade máxima de potência maior que 0 dobro do apresentado pelo catalisador comercial Pt/C Basf. A ordem final de densidade máxima de potência exibida por área do eletrodo foi: $\mathrm{PtRh} / \mathrm{C}>\mathrm{PtRh} / \mathrm{C}$ (100) $>\mathrm{Pt} / \mathrm{C}>\mathrm{Pt} / \mathrm{C}$ Basf $>\mathrm{Pt} / \mathrm{C}$ (100).

Quando normalizamos o resultado por área eletroquimicamente ativa de metal, novamente é observado um aumento significativo no desempenho dos materiais com orientação preferencial (100), uma vez que estes apresentam um maior tamanho de cristalito como já comentado. Assim o resultado mostra que o eletrocatalisador Pt/C (100) é quem expõe maior densidade máxima de potência produzida para a GOR, seguido do PtRh/C (100) > PtRh/C > Pt/C > Pt/C Basf.

Em suma, podemos afirmar que os materiais binários $\mathrm{PtRh} / \mathrm{C}$ (com ou sem orientação) apresentaram melhor desempenho eletrocatalítico para ambas reações propostas (EOR e GOR) e ainda que os materiais com orientação preferencial na direção (100) são bem mais ativos quando consideramos sua área eletroquimicamente ativa.

5.7.2 Estudos on-line da eletro-oxidação do glicerol por espectrometria de massas diferencial (DMS) e análise dos efluentes da DGFC por ATR-FTIR

Como já comentado, a GOR é mais complexa que a do etanol e pode gerar vários produtos. Assim, observamos a ocorrência da geração de produtos da GOR em meio ácido sobre catalisadores a base de platina que são comumente relados nos estudos anteriores, sendo apresentados na Tabela 9 a seguir. 
Tabela 9 - Produtos da oxidação parcial do glicerol em meio ácido sob eletrocatalisadores a base de platina, suas massas moleculares e bandas detectáveis no FTIR.

\begin{tabular}{|c|c|c|}
\hline Produto & Massa Molecular & $\begin{array}{l}\text { Possíveis bandas de formação } \\
\text { detectáveis no FTIR (em cm-1) }\end{array}$ \\
\hline Ácido fórmico & 46 & 1350 e 1380 \\
\hline Ácido glicólico & 76 & $1250 ; 1326$ e 1410 \\
\hline Ácido oxálico & 90 & 1308 \\
\hline Gliceraldeído & 90 & 1417 \\
\hline Dihidroxiacetona & 90 & 1380 \\
\hline Ácido hidróxi-pirúvico & 104 & 1215 e 1395 \\
\hline Ácido glicérico & 106 & 1317 e 1418 \\
\hline Ácido mesoxálico & 118 & 1334 \\
\hline Ácido tartrônico & 120 & $1280 ; 1335$ e 1363 \\
\hline
\end{tabular}

Fonte: (NIST Chemistry WebBook; GOMES et al. 2014).

Como pode-se observar, existem produtos com mesma massa molecular, além disso as bandas de FTIR relatadas para a formação dos produtos ou são muito próximas umas das outras ou se sobrepõem, fatos que dificultam uma discussão mais conclusiva sobre a ocorrência da formação de alguns desses produtos. Contudo, aqui fazemos uma discussão correlacionando os resultados do experimento de DMS com os de FTIR (assim como feito para os resultados da EOR) para que seja mais confiável e de fácil entendimento. As figuras a seguir apresentam os resultados de DMS obtidos para a GOR. 
Figura 25 - Resultados dos espectrômetros de massas eletroquímica diferencial para os eletrocatalisadores estudados, relacionado aos produtos com $\mathrm{m} / \mathrm{z}$ de 44 a 90 , analisados pelo efluente de uma DGFC.
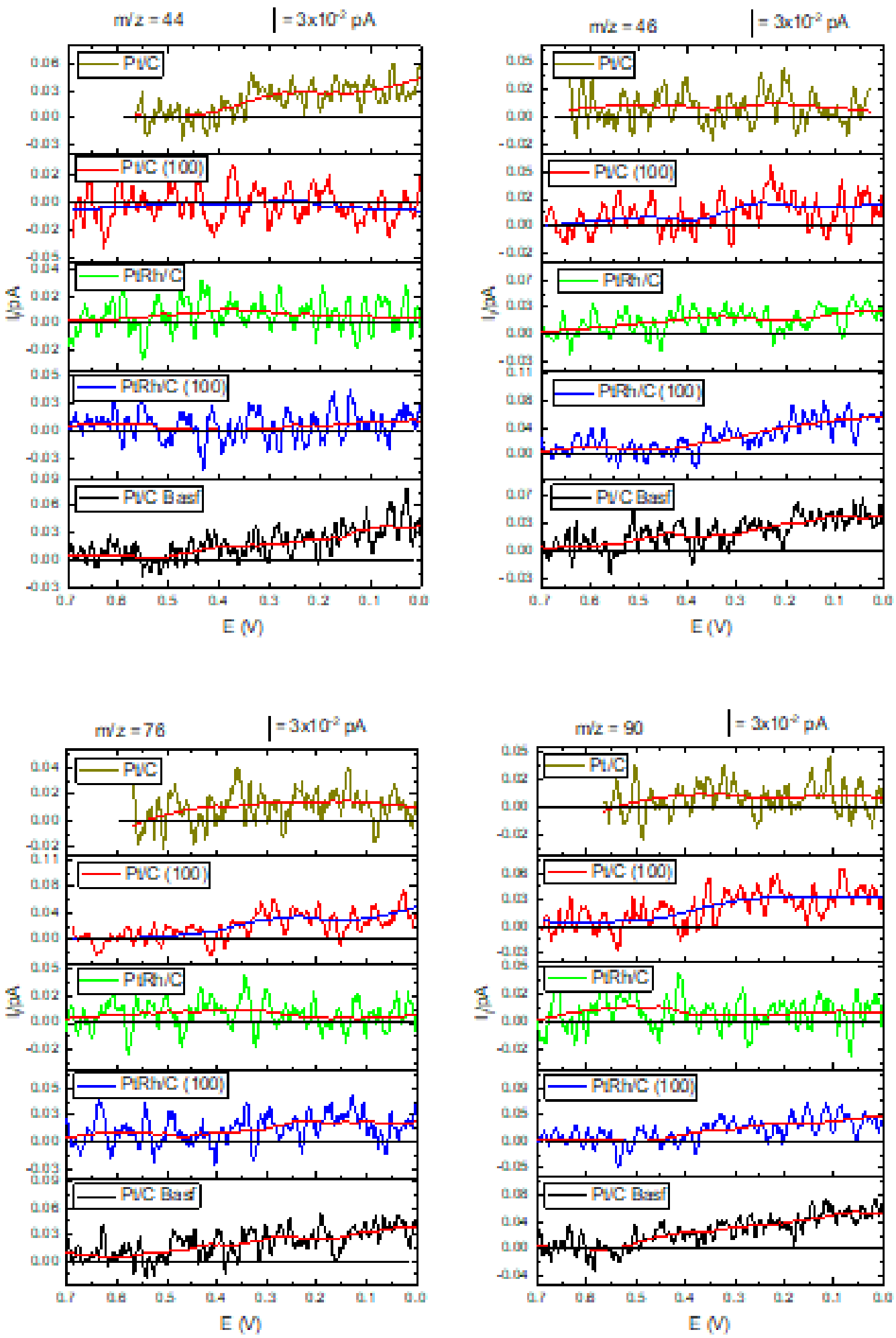

Fonte: Resultado da pesquisa. 
Figura 26 - Resultados dos espectrômetros de massas eletroquímica diferencial para os eletrocatalisadores estudados, relacionado aos produtos com m/z de 104 a 120, analisados pelo efluente de uma DGFC.
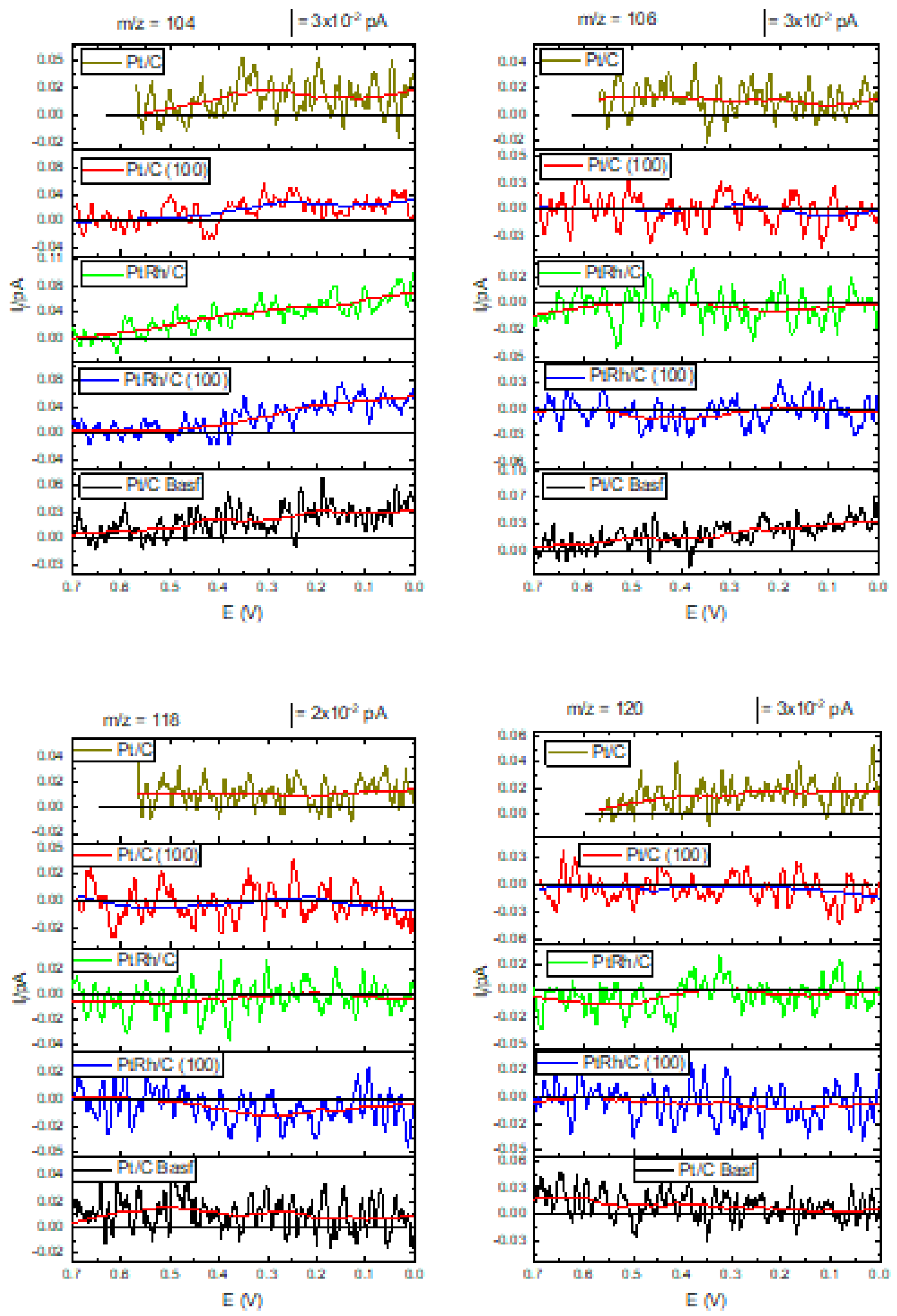

Fonte: Resultado da pesquisa. 
Com relação a formação dos produtos apresentados pelo DMS para o eletrocatalisador Pt/C Basf podemos observar que todos foram detectados, mesmo que com baixa intensidade, sendo os produtos com massa igual 90, 76, 46 e 44 os que apresentaram maior intensidade de detecção com potencial próximo a $0 \mathrm{~V}$. Dentre esses o produto com $\mathrm{m} / \mathrm{z}=76$ foi o que apresentou maior intensidade, em potencial próximo a 0,3 V. Já o ácido mesoxálico $(\mathrm{m} / \mathrm{z}=118)$ apresentou maior intensidade de produção no potencial $0,5 \mathrm{~V}$, e o ácido tartrônico $(\mathrm{m} / \mathrm{z}=120)$ foi detectado com maior intensidade no início do experimento, potencial em $0.7 \mathrm{~V}$, decaindo sua produção com a diminuição do potencial, apresentando sinal aproximadamente nulo (zero) a partir de 0,2 V.

Os resultados de FTIR referentes à GOR para os eletrocatalisadores $\mathrm{Pt} / \mathrm{C}$ Basf e Pt/C são apresentados na Figura 27, onde os três maiores picos observados em todos os espectros de FTIR, em aproximadamente $995 \mathrm{~cm}^{-1}, 1045$ $\mathrm{cm}^{-1}$ e $1110 \mathrm{~cm}^{-1}$ são referentes ao glicerol (NIST Chemistry WebBook; GOMES et al. 2014).

Figura 27 - Resultados dos experimentos de espectroscopia na região do infravermelho com transformada de Fourier e refletância total atenuada, analisados pelo efluente de uma DGFC, para os eletrocatalisadroes Pt/C Basf, em a) e Pt/C em b).
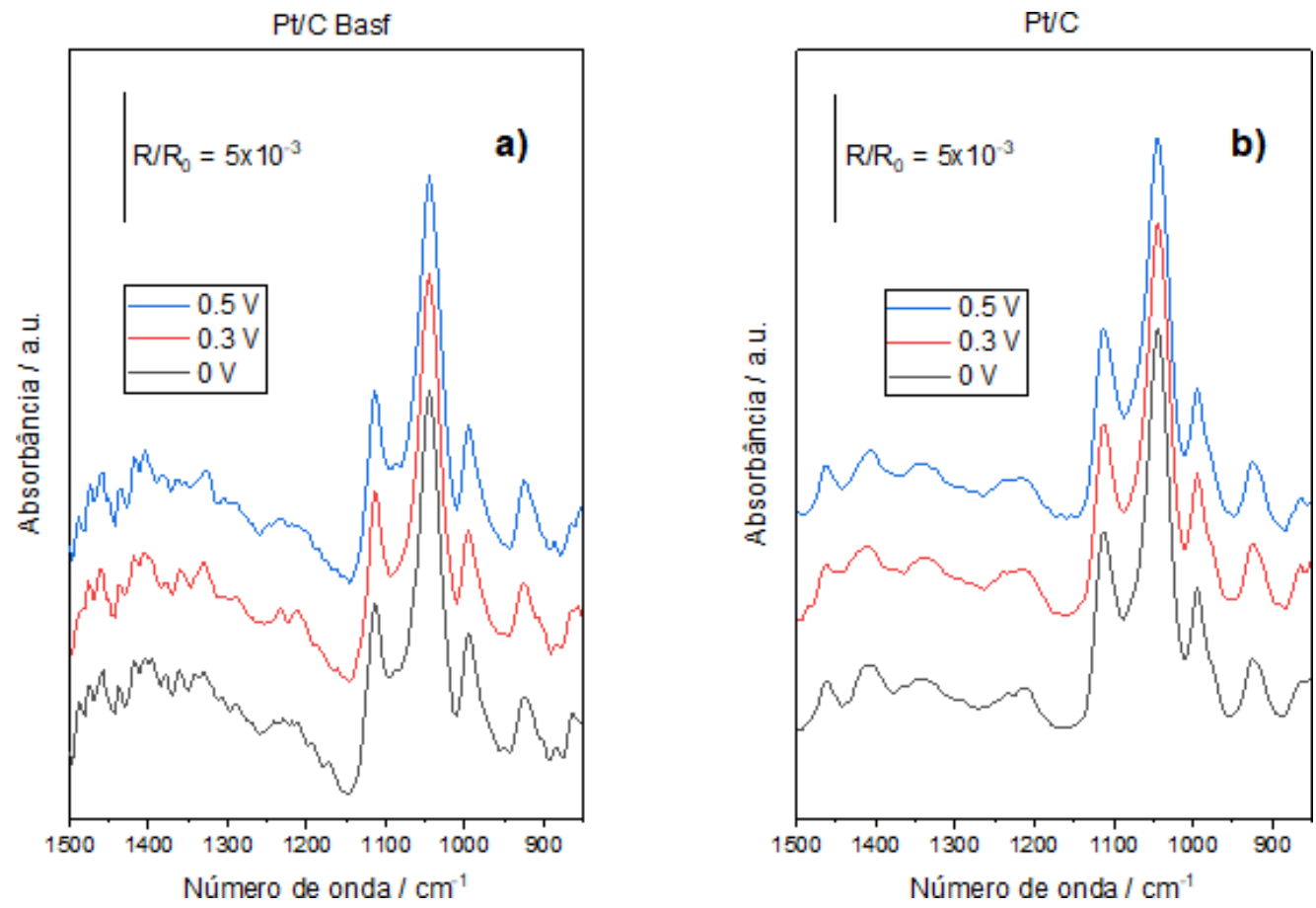

Fonte: Resultado da pesquisa. 
Com os resultados apresentados pela Figura 27a podemos observar a formação das bandas relativas aos produtos detectados no DMS, onde a banda referente à formação do ácido fórmico foi observável em $1380 \mathrm{~cm}^{-1}$, indicando uma possível coexistência desse com a dihidroxiacetona. Com relação aos demais produtos formados o ácido glicólico apresentou apenas uma única banda possível verificar em aproximadamente $1326 \mathrm{~cm}^{-1}$, o ácido oxálico em $1308 \mathrm{~cm}^{-1}$, gliceraldeído em $1417 \mathrm{~cm}^{-1}$ possivelmente com sobreposição da banda relativa ao ácido glicérico em $1418 \mathrm{~cm}^{-1}$ (não apresentou formação em $1317 \mathrm{~cm}^{-1}$ ), ácido hidróxi-pirúvico foi detectável em aproximadamente $1215 \mathrm{~cm}^{-1}$ mas não é possível visualizar em $1395 \mathrm{~cm}^{-1}$. A formação do ácido mesoxálico foi observado em 1334 $\mathrm{cm}^{-1}$, possivelmente coexistindo e apresentando sobreposição da banda referente ao ácido tartrônico em $1335 \mathrm{~cm}^{-1}$, o qual também apresentou formação em 1363 $\mathrm{cm}^{-1}$.

Para o Pt/C a maior intensidade apresentada pelo experimento de DMS foi com ralação ao $\mathrm{CO} 2(\mathrm{~m} / \mathrm{z}=44)$, seguido do ácido hidroxipirúvico $(\mathrm{m} / \mathrm{z}=104)$. Todos os outros produtos também foram detectados, sendo em sua maioria com formação iniciado em aproximadamente 0,5 V. Já com relação aos resultados apresentados pelo FTIR (Figura 27b) algumas diferenças foram observadas em comparação ao Pt/C Basf, sendo a primeira delas a não detecção da banda referente à dihidroxiacetona em $1380 \mathrm{~cm}^{-1}$, indicando que possivelmente este catalisador não produziu este composto. Além disso, foi possível observar uma banda larga equivalente, provavelmente, à formação do ácido glicólico e ácido fórmico, iniciando em aproximadamente $1326 \mathrm{~cm}^{-1}$ sendo observável até próximo de $1350 \mathrm{~cm}^{-1}$. A banda que indica a formação do ácido oxálico em $1308 \mathrm{~cm}^{-1}$ também não foi detectada, indicando assim que os produtos com relação $\mathrm{m} / \mathrm{z}=90$ detectados no DEMS se deve unicamente à formação do gliceraldeído detectado em $1417 \mathrm{~cm}^{-1}$, banda esta que provavelmente também indica a formação ácido glicérico em $1418 \mathrm{~cm}^{-1}$. As demais bandas observadas coincidem com as já discutidas para o Pt/C Basf.

O eletrocatalisador Pt/C (100) não apresentou formação de $\mathrm{CO}_{2}$ relevante pelo experimento de DMS, sendo que a partir de $0,2 \mathrm{~V}$ foi detectado sinal negativo para este produto, confirmando a não detecção deste durante 0 experimento. Além disso, os produtos com m/z $=106,118$ e 120 também apresentaram sinal negativo durante a maior parte de realização do experimento, 
indicando que este eletrocatalisador também não produziu quantidades significativas desses compostos. Contudo vale ressaltar que a observação somente da linha padrão (linha em vermelho) pode nos levar a uma conclusão equivocada, uma vez que o resultado real do DMS é apresentado com bastante ruído e consequentemente pode haver potenciais específicos e estreitos em que há formação dos produtos que apresentaram padrão negativo de detecção. Para os produtos com massa igual a 46, 76, 90 e 104 foi detectado produção a partir do potencial próximo a $0,4 \mathrm{~V}$, sendo equivalente as bandas relativas a formação desses produtos no FTIR (Figura 28a), porém elas aparecem apenas nos potenciais 0,3 e $0 \mathrm{~V}$.

Figura 28 - Resultados dos experimentos de espectroscopia na região do infravermelho com transformada de Fourier e refletância total atenuada, analisados pelo efluente de uma DGFC, para os eletrocatalisadroes Pt/C (100), em a) e PtRh/C em b).
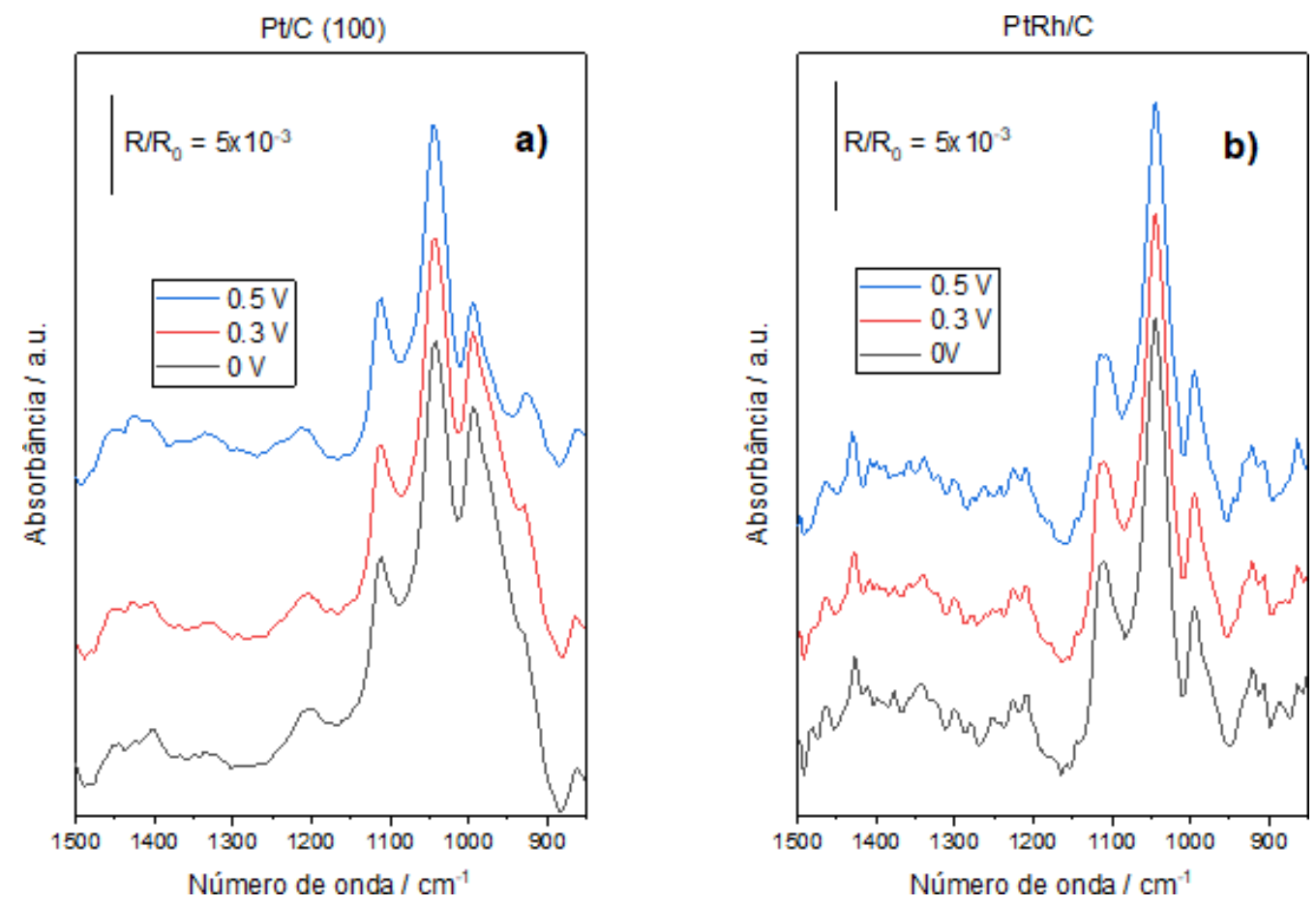

Fonte: Resultado da pesquisa.

Para o eletrocatalisador PtRh/C também foi observado detecção negativa com relação à formação dos produtos com m/z =106, 118 e 120, indicando assim que esses produtos não foram formados. A maior intensidade observada se deu para o ácido hidróxipirúvico $(\mathrm{m} / \mathrm{z}=104)$, sendo que este produto começou a ser formado em aproximadamente $0,65 \mathrm{~V}$ e apresentou curva crescente de 
produção até o fim do experimento de DMS. Outro produto que apresentou sinal de detecção relativamente alto foi o ácido fórmico $(\mathrm{m} / \mathrm{z}=46)$, sendo que os demais produtos apresentaram maior intensidade de sinal em aproximadamente 0,4 V, com exceção dos produtos com $\mathrm{m} / \mathrm{z}=90$ que apresentaram maior intensidade em 0.5 V. Esses resultados são equivalentes com os apresentados pelo FTIR (Figura 28b), uma vez que os produtos detectados pelo DMS apresentaram suas bandas características no FTIR.

Expondo resultados similares ao $\mathrm{PtRh} / \mathrm{C}$ o eletrocatalisador $\mathrm{PtRh} / \mathrm{C}$ (100) também apresentou intensidades de detecção negativas para os produtos com massa igual a 106, 118 e 120. O produto que demonstrou maior sinal positivo detectado (DMS) também foi o ácido hidróxipirúvico $(\mathrm{m} / \mathrm{z}=104)$, contudo sua formação teve maior incremento a partir de 0,45 V aproximadamente. A maior diferença observada foi com relação aos produtos com massa igual a 76 e 90, onde o PtRh/C (100) apresentou maior intensidade de formação para esses produtos e ainda incremento na formação desses a partir de 0,4 V aproximadamente, enquanto que o $\mathrm{PtRh} / \mathrm{C}$, em contrapartida, demonstra diminuição de formação para esses produtos quando o potencial também é diminuído. Com relação a produção de $\mathrm{CO}_{2}$ $(\mathrm{m} / \mathrm{z}=44)$ ambos catalisadores apresentaram baixa intensidade. Porém para a formação do ácido fórmico $(\mathrm{m} / \mathrm{z}=46)$ o eletrocatalisador $\mathrm{PtRh} / \mathrm{C}(100)$ demonstrou intensidade pouco maior e padrão de produção crescente com a diminuição do potencial aplicado. A maior intensidade gerada para os produtos com massa igual a 90 pode ser explicada pela formação do gliceraldeído em $1417 \mathrm{~cm}^{-1}$ (Figura 29) pelo eletrocatalisador PtRh/C (100), banda não formada para o PtRh/C. 
Figura 29 - Resultados dos experimentos de espectroscopia na região do infravermelho com transformada de Fourier e refletância total atenuada, analisados pelo efluente de uma DGFC, para o eletrocatalisador PtRh/C (100).

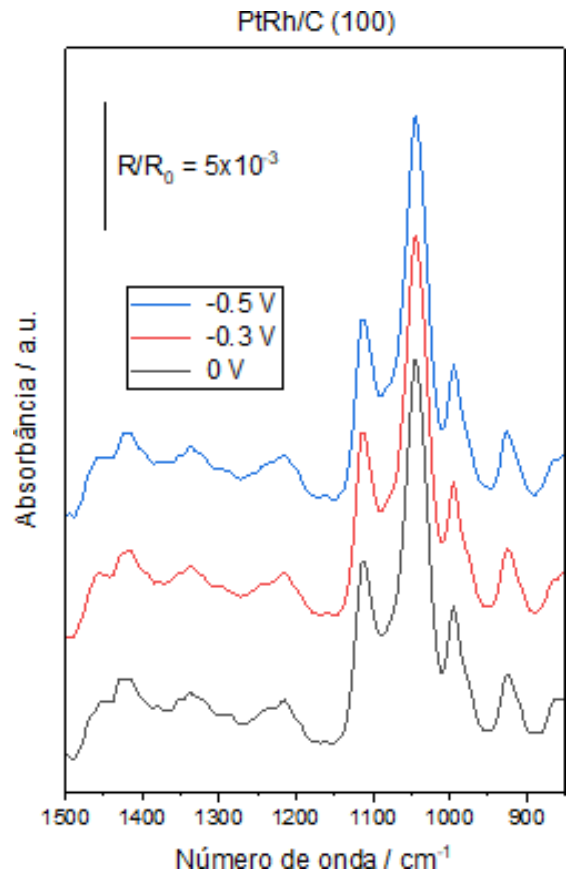

Fonte: Resultado da pesquisa. 
De acordo com os resultados mostrados podemos concluir que a síntese realizada pelo método da redução por álcool utilizando $\mathrm{KBr}$ como agente direcionador de estrutura foi efetivo para obtenção de nanopartículas de Pt/C e $\mathrm{PtRh} / \mathrm{C}$ com orientação preferencial na direção (100). Foi verificado também que os eletrocatalisadores com orientação preferencial forneceram maiores valores de densidade de corrente por área eletroquimicamente ativa para a EOR pela técnica de VC, além de exibirem menores potenciais para eletro-oxidação de uma monocamada de $\mathrm{CO}$ quando comparados aos eletrocatalisadores de $\mathrm{Pt} / \mathrm{C}$ comercial (Basf), Pt/C e PtRh/C com nanopartículas sem orientação preferencial.

Pode-se observar pelos resultados dos experimentos em célula unitária que os materiais binários PtRh/C (com ou sem orientação) apresentaram melhor desempenho eletrocatalítico para as reações propostas (EOR e GOR) e ainda que os materiais com orientação preferencial na direção (100) se apresentam bem mais ativos quando consideramos sua área eletroquimicamente ativa.

Com relação a EOR os experimentos de DMS on-line e medições de ATR - FTIR revelaram que os eletrocatalisadores Pt/C e PtRh/C com orientação preferencial na direção (100) levam à formação preferencial de produtos mais oxidados, como ácido acético e $\mathrm{CO}_{2}$.

Para a GOR os resultados de DMS e ATR - FTIR mostraram que para os eletrocatalisadores $\mathrm{Pt} / \mathrm{C}$ e Pt/C Basf policristalinos foi observado a detecção dos sinais de todas as espécies estudadas $(\mathrm{m} / \mathrm{z}=44,46,76,90,104,106,118$ e 120) em praticamente toda a faixa de potencial. Para o eletrocatalisador $\mathrm{PtRh} / \mathrm{C}$ sem orientação preferencial a deteç̧ão dos sinais $\mathrm{m} / \mathrm{z}=44,46,76,90$ e 104 foi observada praticamente em toda a faixa de potencial, porém, as espécies $\mathrm{m} / \mathrm{z}=$ 106, 118 e 120 não foram observadas. Para os eletrocatalisadores com orientação preferencial Pt/C (100) e PtRh/C (100) não foram observados a detecção das espécies $\mathrm{m} / \mathrm{z}=44,106,118$ e 120. Estes eletrocatalisadores apresentaram-se mais seletivos para a formação dos seguintes compostos: $\mathrm{m} / \mathrm{z}=46$ (ácido fórmico), $\mathrm{m} / \mathrm{z}$ = 76 (ácido glicólico), $\mathrm{m} / \mathrm{z}=90$ (gliceraldeído) e m/z = 104 (ácido hidroxi-piruvíco) na faixa de potencial entre 0.5 e $0 \mathrm{~V}$. 


\section{$7 \quad$ TRABALHOS FUTUROS}

Os eletrocatalisadores $\mathrm{Pt} / \mathrm{C}$ e $\mathrm{PtRh} / \mathrm{C}$ com orientação preferencial na direção (100) apresentaram bons desempenhos eletrocatalíticos quando consideramos suas áreas eletroquimicamente ativas e também foram mais seletivos em relação aos materiais policristalinos. No entanto, estes eletrocatalisadores apresentaram tamanhos médios de cristalito na faixa de 8-9 nm. Assim, seria importante investigar o desenvolvimento de metodologias de sínteses buscando reduzir o tamanho destas nanopartículas, para tamanhos menores que $5 \mathrm{~nm}$, pode levar a materiais com excelentes desempenhos.

Além disso, a preparação de eletrocatalisadores de $\mathrm{PtRh}+\mathrm{SnO}_{2} / \mathrm{C}$ ou PtRhSn/C contendo nanopartículas de PtRh ou PtRhSn com orientação preferencial na direção (100) pode ser também uma forma interessante de obter materiais mais ativos para a eletro-oxidação do etanol (EOR) e do glicerol (GOR). 


\section{REFERÊNCIAS BIBLIOGRÁFICAS}

APERGIS, N. DANULETIU, D. C.; Renewable Energy and Economic Growth: Evidence from the Sign of Panel Long-Run Causality. International Journal of Energy Economics and Policy. v. 4, n. 4, p. 578-587, 2014.

ANTONIASSI, R. M.; OLIVEIRA NETO, A.; LINARDI, M.; SPINACÉ, E. V.; The effect of acetaldehyde and acetic acid on the direct ethanol fuel cell performance using PtSnO2/C electrocatalysts. International Journal Of Hydrogen Energy. v. 38, p. 12069-12077, 2013.

ANTONIASSI, R.M. Desempenho elétrico e distribuição dos produtos da célula a combustível com etanol direto utilizando Pt/C, PtSn/C(liga) e PtSnO $2 / C$ como eletrocatalisadores anódicos. 2013. 68 p. Dissertação (Mestrado em Tecnologia Nuclear). Instituto de Pesquisas Energéticas e Nucleares, São Paulo.

ANTONIASSI, R.M. Preparação de nanopartículas de platina com diferentes morfologias nos materiais $\mathrm{Pt} / \mathrm{C}$ e $\mathrm{PtSnO} \mathrm{O}_{2} / \mathrm{C}$ para aplicação como ânodo em células a combustível de etanol direto. 2017.93 p. Tese (Doutorado em Tecnologia Nuclear). Instituto de Pesquisas Energéticas e Nucleares, São Paulo.

AHMAD, M. S.; AB RAHIM, M. H.; ALQAHTANI, T. M.; WITOON, T.; LIM, J.; CHENG, C. K. A review on advances in green treatment of glycerol waste with a focus on electro-oxidation pathway. Chemosphere, v. 276, August, 2021.

ARAUJO, H. R. Eletro-oxidação de Glicerol em Eletrodos de Pt e PtRh em Meio Ácido: Estudo da Variação de Temperatura e da Composição dos Catalisadores. 2013. 64 p. Dissertação (Mestrado em Química). Centro de Ciências Exatas e Tecnologia. Universidade Federal do Maranhão, São Luis.

BONIFÁCIO, R. N.; LINARDI, M. Desenvolvimento de processo de produção de conjuntos eletrodo-membrana-eletrodo para células a combustível baseadas no uso de membrana polimérica condutora de prótons (PEMFC) por impressão a tela. Química Nova, v.34, p. 96-100, 2011.

BRANDALISE, M. Preparação e caracterização de eletrocatalisadores $P t R u / C$, PtBi/C, PtRuBi/C para eletro-oxidação direta de etanol em células a combustível tipo PEM utilizando a metodologia da redução via borohidreto de sódio. 2010. 101 p. Dissertação (Mestrado em Ciências na Área de Tecnologia Nuclear). Instituto de Pesquisa Energéticas e Nucleares, São Paulo. 
BUSO-ROGERO, C.; GROZOVSKI, V.; VIDAL-IGLESIAS, F. J.; SOLLA-GULLÓN, J.; HERRERO, E.; FELIU, J. M. Surface Structure And Anion Effects In The Oxidation Of Ethanol On Platinum Nanoparticles. Journal of Materials Chemistry A, v. 24, n. 1, p. 7068-7076, 2013.

CHEN, Y.; JIANG, J. X.; CHEN, P.; LIU, H. M.; HAN, S. H.; Porous Trimetallic PtRhCu Cubic Nanoboxes for Ethanol Electrooxidation. Advanced Energy Materials. v. 8, ed. 24, 2018.

CHEN, Y.; SHI, J.; CHEN, S. Small-Molecule $\left(\mathrm{CO}, \mathrm{H}_{2}\right)$ Electro-Oxidation as an Electrochemical Tool for Characterization of Ni@Pt/C with Different Pt Coverages. The Journal of Physical Chemistry C, v. 119, p. 7138-7145, 2015.

COLMATI, F; TREMILIOSI-FILHO, G; GONZALEZ, E. R.; BERNÁ, A.; HERRERO, E.; FELIU, J.M. Surface structure effects on the electrochemical oxidation of ethanol on platinum single crystal electrodes. Faraday Discussions, v. 140, p. 379-397, 2009.

COUTANCEU, C.; URCHAGA, P.; BARATON, S. Diffusion of adsorbed CO on platinium (100) and (111) oriented nanosurfaces. Electrochemistry Communications, v. 22, p. 109-112, 2012.

COUTANCEU, C.; BARANTON, S.; KOUAMÉ, R. S. B. Selective Electrooxidation of Glycerol Into Value-Added Chemicals: A Short Overview. Frontiers in Chemistry, v. 7, article 100, 2019.

DE SOUZA, J. P. I.; QUEIROZ, S. L.; BERGAMASKI, K.; GONZALES, E. R.; NART, F. C. Electro-Oxidation of Ethanol on Pt, Rh, and PtRh Electrodes. A Study Using DEMS and in-Situ FTIR Techniques. The Journal of Physical Chemistry B, 106, 38, p. 9825-9830, 2002.

DEVIVARAPRASAD. R.; NEERGAT, M.; RAMESH, R.; NARESH, N.; KAR, T.; SINGH, R. K. Oxygen Reduction Reaction and Peroxide Generation on ShapeControlled and Polycrystalline Platinum Nanoparticles in Acidic and Alkaline Electrolytes. Langmuir, v. 30, n. 29, p. 8995-9006, 2014.

DIAS, R. R. Preparação de eletrocatalisadores PtRu/C, PtSn/C, PtRh/C, $P t R u R h / C$ e PtSnRh/C para oxidação direta de alcoóis em células a combustível tipo PEM utilizando a metodologia de redução por álcool. 2009. 71 p. Dissertação (Mestrado em Ciências na Área de Tecnologia Nuclear). Instituto de Pesquisa Energéticas e Nucleares, São Paulo. 
DRESCH, M. A. Aplicação De Catalisadores PtSn/C e Membranas Nafion-Sio2 em Células a Combustível de Etanol Direto em Elevadas Temperaturas. 2014. 117 p. Tese (Doutorado em Ciências na Área de Tecnologia Nuclear). Instituto de Pesquisa Energéticas e Nucleares, São Paulo.

DRESCH, M. A. Síntese e caracterização eletroquímica de membranas híbridas Nafion ${ }^{\circledR}$-SiO2 para aplicação como eletrólito polimérico em células a combustível tipo PEMFC. 2009. 108 p. Dissertação (Mestrado em Ciência na Área de Tecnologia Nuclear). Instituto de Pesquisa Energéticas e Nucleares, São Paulo.

FERNANDES, V. C.; DA CUNHA, E. F.; BONIFÁCIO, R. N.; DRECH, M. A.; DOUBEK, G.; SANTIAGO, E. I.; LINARDI, M. Desenvolvimento de tecnologia para confecção de eletrodos e conjuntos eletrodo-membrana-eletrodo (MEA) por impressão a tela para aplicação em módulos de potência de células PEMFC. Química Nova, v.35, p. 775-779, 2012.

FONTES, E. H. Oxidação Eletroquímica do Etanol Utilizando Eletrocatalisadores PtRh/C em Meio Alcalino e Sintetizados via Borohidreto de Sódio e Redução por Álcool. 2017. 108 p. Dissertação (Mestrado em Tecnologia Nuclear). Instituto de Pesquisas Energéticas e Nucleares, São Paulo.

GOMES, J. F.; DE PAULA, F. B.C.; GASPAROTTO, L. H. S.; TREMILIOSI-FILHO, $G$. The influence of the Pt crystalline surface orientation on the glycerol electrooxidation in acidic media. Electrochimica Acta, v. 76, p. 88-93, 2012.

GOMES, J. F.; MARTINS, C. A.; GIZ, M. J.; TREMILIOSI-FILHO, G.; CAMARA, G. A. Insights into the adsorption and electro-oxidation of glycerol: Self-inhibition and concentration effects. Journal of Catalysis, v. 301, p. 154-161, 2013.

GOMES, J. F.; GARCIA, A. C.; GASPAROTO, L. H. S.; DE SOUZA, N. E.; FERREIRA, E. B.; PIRES, C.; TREMILIOSI-FILHO, G. Influence of silver on the glycerol electro-oxidation over AuAg/C catalysts in alkaline medium: a cyclic voltammetry and in situ FTIR spectroscopy study. Electrochimica Acta, v. 144, p. 361-368, 2014.

HUANG, X.; SHAO, Q.; BU, L.; ZHU, Y. Subnanometer PtRh Nanowire with Alleviated Poisoning Effect and Enhanced C-C Bond Cleavage for Ethanol Oxidation Electrocatalysis. ACS Catalysis. v. 9, p. 6607-6612, 2019. 
IGAMI, M. P. Z. (Org) ; VIEIRA, M. M. F.(Org.) Guia para a elaboração de teses e dissertações: programa de Pós-graduação Tecnologia Nuclear - IPEN/USP . 3 ed. São Paulo: Instituto de Pesquisas Energéticas e Nucleares, 2017. Disponível em:

$<$ https://www.ipen.br/portal por/conteudo/biblioteca/arquivos/GuialPEN 2017-1024 versao 4.pdf > Acesso em: 04/2021.

KAMARUDIN, S. K.; AKHAIRI, M. A. F. Catalysts in direct ethanol fuel cell (DEFC): An overview. International Journal Of Hydrogen Energy. v. 41, ed. 7 , p. 4214-4228, 2016.

KOWAL, A.; LI, M.; SHAO, M.; SASAKI, K.; VUKMIROVIC, M.B.; ZHANG, J.; MARINKOVIC, N. S.; LIU, P.; FRENKEL, A. I.; ADZIC, R.R. Ternary Pt/Rh/SnO2 electrocatalysts for oxidizing ethanol to $\mathrm{CO}_{2}$. Nature Materials, v. 8, n.4, p. 325330, 2009.

LI, M.; ZHOU, P. W.; MARINKOVIC, N. S.; SASAKI, K.; ADZIC, R. R. The role of rhodium and tin oxide in the platinum-based electrocatalysts for ethanol oxidation to $\mathrm{CO}_{2}$. Electrochimica Acta, v. 104, p. 454-461, 2013.

LINARDI, M. Introdução à Ciência e Tecnologia de Células a Combustível. São Paulo, Ed. ArtLiber, 1ª edição, 2010.

LINSTROM, P. J.; MALLARD, W. G. NIST Chemistry WebBook, NIST Standard Reference Database Number 69. Disponível em:

<https://webbook.nist.gov/chemistry/> Acesso em: 15 jun. 2021.

MARCZYNSKI, E. S. Avaliação de Membranas Eletrólito Hidrocarbônicas não Fluoradas Para uso em Célula a Combustível Tipo DEFC. 2013. 96 p. Dissertação (Mestrado em Engenharia, área de concentração Ciência e Tecnologia dos Materiais). Departamento de Materiais da Escola de Engenharia da Universidade Federal do Rio Grande do Sul, Porto Alegre.

MOTA, C. J. A.; DA SILVA, C. X. A.; GONÇALVES, V. L. C. Gliceroquímica: novos produtos e processos a partir da glicerina de produção de biodiesel. Química Nova, vol. 32, n. 3, p. 639-648, 2009. 
MOSTAFAZADEH, A. K.; DE LA TORRE, M. S.; PADILLA, Y.; DROGUI, P.; BRAR, S. K.; TYAGI, R. D.; BIHAN, Y. L.; BUELNA, G.; MOROYOQUI, P. G. An insight into an electro-catalytic reactor concept for high valueadded production from crude glycerol: Optimization, electrode passivation, product distribution, and reaction pathway identification. Renewable Energy, v. 172, p. 130-144, 2021.

OLIVEIRA NETO, A.; DIAS, R. R.; RIBEIRO, A.; SPINACÉ, E. V.; M, LINARDI. Eletro-oxidação de etanol sobre eletrocatalisadores $\mathrm{PtRh} / \mathrm{C}, \mathrm{PtSn} / \mathrm{C}$ e PtSnRh/C preparados pelo método da redução por álcool. Eclética Química, v. 31, n.1, p. $81-88,2006$.

RAHIM, S. A. N. M.; LEE, C. S.; ABNISA, F.; AROUA, M. K.; DAUD, W. A. W.; COGNET, P.; PÉRĖS, Y. A review of recent developments on kinetics parameters for glycerol electrochemical conversion - A by-product of biodiesel. Science of the Total Environment, v. 705, 2020.

SALAZAR-BANDA, G. R.; EGUILUZ, K. I. B.; RUSSEL, A. E.; CAMARA, G. A.; GAIOTTI, A. C.; HUANG, H.; FERREIRA, D. S.; ALMEIDA, C. V. S. Highly active $\mathrm{Pt}_{3} \mathrm{Rh} / \mathrm{C}$ nanoparticles towards ethanol electrooxidation. Influence of the catalyst structure. Applied Catalysis B: Environmental. v. 254, p. 113-127, 2019.

SEN GUPTA, S.; DATTA, J. A comparative study on ethanol oxidation behavior at Pt and PtRh electrodeposits. Journal of Electroanalytical Chemistry, v. 594, n. 1, p. 65-72, 2006.

SHEN, S. Y.; ZHAO, T. S.; XU, J. B. Carbon supported PtRh catalysts for ethanol oxidation in alkaline direct ethanol fuel cell. International Journal of Hydrogen Energy, v. 35, ed. 23, p. 12911-12917, 2010.

SONG, L.; DU, Y.; SHIRAISHI, Y.; WANG, C.; SONG, T.; WANG, J.; SONG, P.; ZHANG, Y.; GAO, F. Precursor-mediated Size Tuning of monodisperse PtRh Nanocubes as Efficient Electrocatalysts for Ethylene Glycol Oxidation. Journal of Materials Chemistry A. ed. 13, p. 7891-7896, 2019.

SPINACÉ, E. V.; ANTONIASSI, R. M.; OTUBO, L.; VAZ, J. M.; OLIVEIRA NETO, A. Synthesis of Pt nanoparticles with preferential (100) orientation directly on the carbon support for Direct Ethanol Fuel Cell. Journal of Catalysis. v. 342, p. 6774, 2016. 
TREMILIOSI FILHO, G.; DOS SANTOS, V. P. Correlação Entre a Estrutura Atômica Superficial e o Processo de Adsorção-Dessorção Reversível de Hidrogênio em Eletrodos Monocristalinos Pt(111), Pt(100) e Pt(110). Química Nova, v. 24, n. 6, p. 856-863, 2001.

URCHAGA, P.; BARATON, S.; COUTANCEU, C. Changes in $\mathrm{CO}_{\text {chem }}$ oxidative stripping activity induced by reconstruction of $\mathrm{Pt}(111)$ and (100) surface nanodomains. Electrochimica Acta, v. 92, p. 438-445, 2013.

U.S. DEPARTMENT OF ENERGY. Fuel Cell Handbook. Morgantown, West Virginia, 2000.

WANG, H.; TONG, X.; SUN, S.; MOHAMEDI, M. Nanostructured shrub-like bimetallic PtxRh100-x alloys grown on carbon paper for the oxidative removal of adsorbed carbon monoxide for ethanol fuel cells reaction. Electrochimica Acta, v. 355, 2020.

WENDT H.; GÖTZ, M.; LINARDI, M. Tecnologias de células a combustível. Química Nova, v.23, n.4, p.538-546, 2000.

XIE, S.; LIU, M.; CHEN, X.; ZHANG, Q.; WANG, W.; LIAO, X.; LYU, Z.; CHENG, Y.; XUE, F.; YE, J.; LIU, K.; LI, P. Facilitating the C-C bond cleavage on sub-10 nm concavity-tunable Rh@Pt core-shell nanocubes for efficient ethanol

electrooxidation. Journal of Materials Chemistry A. ed. 7, p. 17987-17994, 2019.

YANG, Y.; WANG, C.; WEI, R.; LAN, B.; ZHU, C. Potential-Dependent Selectivity of Ethanol Complete Oxidation on Rh Electrode in Alkaline Media: A Synergistic Study of Electrochemical ATR-SEIRAS and IRAS. ACS Catalysis. v. 9, p. 40464053, 2019.

YAHYA, N.; KAMARUDIN, S. K.; KARIM, N. Direct Liquid Fuel Cells. 2021. Cap. 5, Direct glycerol fuel cells (DGFCs). p. 115-136.

YE, Y.; JOO, J.; LEE, S.; LEE, J. A direct one-step synthetic route to Pd-Pt nanostructures with controllable shape, size, and composition for electrocatalytic applications. Journal of Materials Chemistry A, ed. 45, p. 19239-19246, 2014.

ZANATA, C. R.; FERNÁNDEZ, P. S.; TROIANI, H. E.; SALDATI, A. L.; LANDERS, R.; CAMARA, G. A.; CARVALHO, A. E.; MARTINS, C. A. Rh-decorated PtIrOx nanoparticles for glycerol electrooxidation: Searching for a stable and active catalyst. Applied Catalysis B: Environmental, v. 181, p. 445-455, 2016. 
INSTITUTO DE PESQUISAS ENERGÉTICAS E NUCLEARES

Diretoria de Pesquisa, Desenvolvimento e Ensino

Av. Prof. Lineu Prestes, 2242 - Cidade Universitária CEP: 05508-000

Fone/Fax(0XX11) 3133-8908

SÃO PAULO - São Paulo - Brasil

http://www.ipen.br

O IPEN é uma Autarquia vinculada à Secretaria de Desenvolvimento, associada à Universidade de São Paulo e gerida técnica e administrativamente pela Comissão Nacional de Energia Nuclear, órgão do

Ministério da Ciência, Tecnologia, Inovações e Comunicações. 